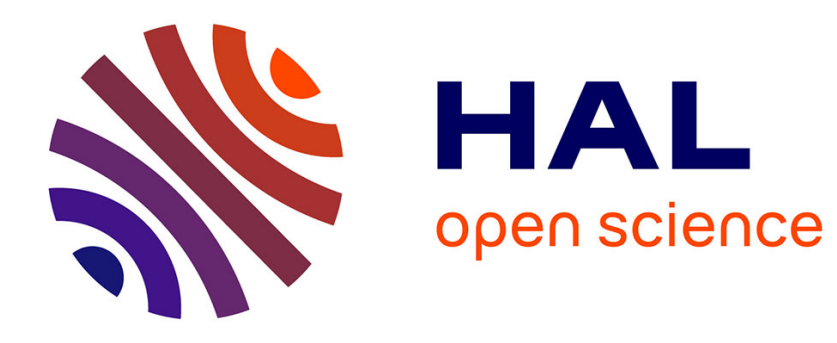

\title{
In situ formation of pyronin dyes for fluorescence protease sensing
}

Sylvain Debieu, Anthony Romieu

\section{To cite this version:}

Sylvain Debieu, Anthony Romieu. In situ formation of pyronin dyes for fluorescence protease sensing. Organic \& Biomolecular Chemistry, 2017, 15 (12), pp.2575 - 2584. 10.1039/c7ob00370f . hal01522066

\section{HAL Id: hal-01522066 https://u-bourgogne.hal.science/hal-01522066}

Submitted on 15 Dec 2021

HAL is a multi-disciplinary open access archive for the deposit and dissemination of scientific research documents, whether they are published or not. The documents may come from teaching and research institutions in France or abroad, or from public or private research centers.
L'archive ouverte pluridisciplinaire HAL, est destinée au dépôt et à la diffusion de documents scientifiques de niveau recherche, publiés ou non, émanant des établissements d'enseignement et de recherche français ou étrangers, des laboratoires publics ou privés. 


\title{
In situ formation of pyronin dyes for fluorescence protease sensing
}

\author{
Sylvain Debieu a and Anthony Romieu ${ }^{* a, b}$
}

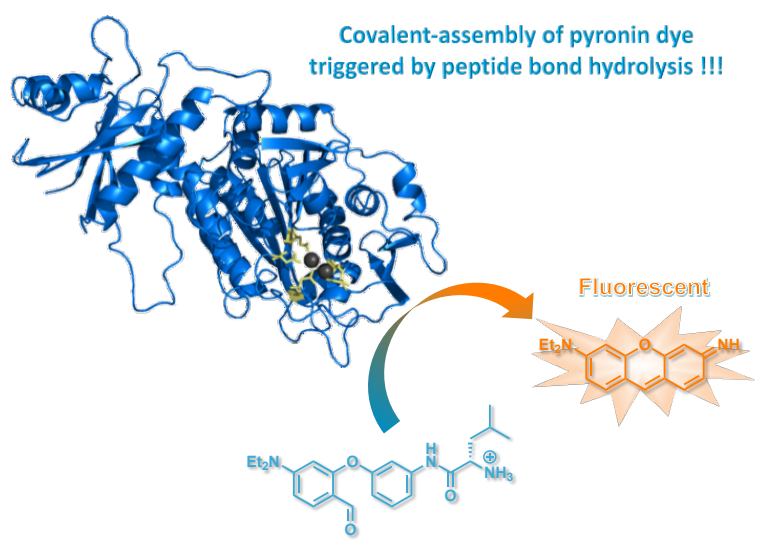

We report a reaction-based strategy for the fluorogenic detection of protease activity. Based on the "covalent-assembly" probe design principle recently put forward by the Yang group for detection of Sarin related threats (J. Am. Chem. Soc., 2014, 136, 6594-6597), we have designed two unusual non-fluorescent caged precursors (mixed bis-aryl ethers) which are readily converted into a fluorescent unsymmetrical pyronin dye through a domino cyclisation-aromatisation reaction triggered by penicillin G acylase (PGA) or leucine aminopeptidase (LAP). Fluorescence-based in vitro assays and HPLC-fluorescence/-MS analyses support the claimed activation mechanism whose the further implementation to "smart" imaging agents for the study of protease function in vivo is expected

\section{Introduction}

During the past decade, reaction-based small-molecule fluorescent probes (also known as fluorescent chemodosimeters, latent or pro-fluorophores) have been widely adopted as valuable (bio)analytical tools for the detection and/or imaging of various (bio)analytes including enzymes, biomolecules, polluting chemicals, cations and anions, in complex biological systems or environmental matrices. ${ }^{1}$ The majority of these chemodosimeters are rationally constructed through the reversible protection of a key functional group of an organic-based fluorophore (typically, an amino or hydroxyl group of a coumarin or xanthene dye). ${ }^{2}$ Despite its many successes, this approach may sometimes lead to unsatisfactory results in terms of selectivity and sensitivity toward the target analyte. This is the consequence of the poor stability of some pro-fluorophores in aq. biological media (some aniline- or phenol-based fluorophores are good leaving groups) and/or their high background fluorescence due to incomplete quenching of the masked fluorophore. In order to remedy these

\footnotetext{
a. Institut de Chimie Moléculaire de l'Université de Bourgogne, UMR 6302, CNRS, Univ. Bourgogne Franche-Comté, 9, Avenue Alain Savary, 21078 Dijon, France. E-mail: anthony.romieu@u-bourgogne.fr; http://www.icmub.fr;

Fax: +33-3-80-39-61-17; Tel: +33-3-80-39-36-24

b. Institut Universitaire de France, 103, boulevard Saint-Michel, 75005 Paris, France.
}

drawbacks, a novel class of reactive fluorescence "turn-on" probes based on the "covalent-assembly" principle has recently emerged. This approach is based on in situ formation of an organic-based fluorophore from a caged bifunctional precursor and through effective (biocompatible) domino reactions, triggered by the target analyte. ${ }^{3}$ The analyte-mediated synthesis of blue-green emitting 7- $N, N$-dialkylamino/7-hydroxy (2-imino)coumarins is often preferred for in vitro (bio)sensing applications ${ }^{4}$ but was also implemented in photoaffinity labeling experiments. ${ }^{5}$ We have recently used this fluorogenic cyclisation reaction for designing dual-input fluorogenic probes (acting as AND molecular logic gates) dedicated to simultaneous detection of two distinct enzyme activities namely hydrolase and reductase. ${ }^{6}$ Furthermore, the Yang group has successfully applied the "covalent-assembly" principle to longer-wavelength fluorescent scaffolds including pyronin B (Fig. 1), phenanthridine, benzo[c]cinnoline and resorufin derivatives, for the detection of Sarin mimics ${ }^{7}, \mathrm{Hg}(\mathrm{II})$ cation $^{8}, \mathrm{MeHg}(\mathrm{I})$ cation $^{9}$ and reactive nitrogen species (RNS) ${ }^{10}$ respectively. However, the majority of these latter probes suffers from a lack of versatility (the chemical cascade is specific to the target analyte and its inherent reactivity and cannot be triggered by an other analyte) preventing (1) their use for sensing a wide range of analytes including enzymes and biomolecules, and (2) a possible further extension of the "covalent-assembly" approach to dual- or multi-analyte detection schemes. ${ }^{11,12}$ In order to 
respond to these challenges, we have decided to investigate in situ formation of pyronin dyes triggered by enzymatic events. Such xanthene-based fluorophores have been selected because their spectral features in the yellow-orange region will be valuable for effective biosensing in complex biological media. Furthermore, the upstream design of pyronin precursors where the two aniline moieties are orthogonally protected will open the way for the next construction of dual-input fluorogenic probes. $^{13}$

In this paper, we report our progress toward the development of an unprecedented class of protease-sensing "smart" fluorescent probes whose the principle mechanism of activation is based on the pyronin assembly triggered by the enzyme itself (Fig. 1).

\section{Results and discussion}

To rapidly establish a proof-of-concept, we have chosen to work with two distinct hydrolases namely penicillin $G$ acylase (PGA, also known as penicillin amidase) and leucine aminopeptidase (LAP from porcine kidney) that have two clear advantages: (1) structurally simple substrates (phenylacetamide and L-leucine amide moieties respectively) than can be easily installed on the pyronin precursor through amidification of its primary aniline and (2) a commercial availability at low or reasonable cost. PGA is widely used as biocatalyst in the synthesis of $\beta$-lactam antibiotics, since it allows for the deprotection of phenylacetyl-protected amines ${ }^{14}$, and often regarded as a valuable of model protease to perform in vitro validations of self-immolative molecular systems used as diagnostic probes, molecular amplifiers or drug delivery systems. ${ }^{15}$ LAP is a metallopeptidase widely studied ${ }^{16}$ as an attractive drug target in anti-cancer and anti-malaria chemotherapies. ${ }^{17}$ Furthermore, placental LAP (P-LAP) was recently identified as a relevant biomarker for predicting perinatal mortality ${ }^{18}$ (e.g., serum P-LAP levels are extremely low among women with foetal death). Interestingly, some selfimmolative fluorogenic reporters for LAP sensing in living cells have been recently developed by the Hasserodt group. ${ }^{19}$

Inspired by the nerve agent detection mechanism reported by Lei and Yang for probe $\mathrm{NA570}^{7}$, we assumed that a quite similar bis-aryl ether derivative for which one of the $N, N$ diethylamino group is replaced by a $N$-acyl primay amino moiety, may act as a fully stable non-fluorescent pyronin precursor. Since the selective enzymatic deprotection of its carboxamide group generates an intermediate that will spontaneously cyclise through intramolecular reaction between the unveiled electron-rich arene moiety and aldehyde to give, after aromatisation a fluorescent unsymmetrical pyronin dye (Fig. 1). Interestingly, the multiple sources of primary amines in the reaction medium (i.e., lysine residues within the active site of protease, released L-leucine and/or primary aniline of intermediate) should lead to in situ formation of a more reactive imine/iminium intermediate ${ }^{20}$ and favor the cyclisation process in this neutral aq. environment.

The synthesis of the two protease-sensitive fluorogenic probes $\mathbf{4}$ and $\mathbf{5}$ was achieved in two or three steps as depicted in Scheme 1. First, 3-iodoaniline was $N$-acylated either with commercial phenylacetyl chloride (PhAc-Cl) or mixed anhydride from Boc-L-leucine and isobutyl chloroformate (IBCF), to give compounds $\mathbf{2}$ and $\mathbf{3}$ in good yields (90\% and 70\% respectively). The key step leading to unsymmetrical bis-aryl ether scaffold is an Ullman ether synthesis from phenol $\mathbf{1}$ and aryl iodide $\mathbf{2}$ or $\mathbf{3}$, performed under conditions previously optimized by the Buchwald group. ${ }^{21}$ The PGA-sensitive fluorogenic probe 4 was readily formed on heating reaction mixture at $130{ }^{\circ} \mathrm{C}$ for $12 \mathrm{~h}$ and isolated in a pure form by conventional flash-column chromatography on silica gel. Conversely, in the case of LAPsensitive probe, this copper-catalysed coupling did not work properly (checking by periodic HPLC-MS monitoring) when the reaction mixture was heated at $90^{\circ} \mathrm{C}$. At higher temperatures, significant degradation of starting materials and targeted coupling product was observed. Finally, removal of the Boc group of crude coupling product was achieved under anhydrous acidic conditions (60\% TFA in DCM) at $0{ }^{\circ} \mathrm{C}$ for $20 \mathrm{~min}$. After removal of TFA under mild conditions (essential to avoid sidereactions leading to degradation and/or premature formation of pyronin derivatives), purification was achieved by semipreparative RP-HPLC to give the TFA salt of LAP-sensitive fluorogenic probe 5 in a low but not optimized yield $(11 \%$ overall yield for the last two steps). All spectroscopic data (see $\mathrm{ESI} \uparrow$ ), especially IR, NMR and mass spectrometry, were in agreement with the structures assigned. Their purity was checked by RP-HPLC and found to be $99 \%$ (4) and 93\% (5) respectively. In addition to these syntheses, we have also prepared an authentic sample of unsymmetrical pyronin 6 (6$\mathrm{N}, \mathrm{N}$-diethylamino-3H-xanthen-3-imine, see Fig. 1 for the corresponding structure) which will be formed upon enzymatic activation of the two probes, and used as reference compound for the fluorescence-based in vitro assays and HPLCfluorescence/-MS analyses (vide infra). This unsymmetrical xanthene-based fluorophore has never been described in the literature but a recent publication from the Lin group about the synthesis of a 7-hydroxycoumarin-pyronin FRET dyad and its use as a ratiometric fluorescent probe for $\mathrm{H}_{2} \mathrm{~S}$ sensing ${ }^{22}$, helped us to devise a synthesis of this unusual pyronin from 4-(N,Ndiethylamino)salicylaldehyde and 3-aminophenol (see ESI $\dagger$ ).

All UV-visible and fluorescence measurements were conducted in phosphate buffer (PB, $100 \mathrm{mM}, \mathrm{pH} 7.6$, simulated physological conditions) containing less than $1 \%$ of $\mathrm{CH}_{3} \mathrm{CN}$ as a co-solvent and the corresponding data are gathered in Table 1 (see Fig. S1-S3 for the corresponding spectral curves). The two protease-sensitive probes $\mathbf{4}$ and $\mathbf{5}$, exhibits a strong electronic absorption in the UV-A range and are not fluorescent, especially in the expected emission range of pyronin 6 (500-600 $\mathrm{nm}$ ), whatever the excitation wavelength used. To demonstrate the feasability of proposed detection mechanism, we also investigated the photophysical properties of pyronin 6 in PB.

Table 1 Photophysical properties of the pobes 4 and 5 and pyronin dye 6 in phosphate buffer (100 mM, pH 7.6) and at $25^{\circ} \mathrm{C}$.

\begin{tabular}{ccccc}
\hline Cmpd & $\begin{array}{c}\text { Abs. max } \\
(\mathrm{nm})\end{array}$ & $\begin{array}{c}\varepsilon \\
\left(\mathrm{M}^{-1} \mathrm{~cm}^{-1}\right)\end{array}$ & $\begin{array}{c}\text { Em. max } \\
(\mathrm{nm})\end{array}$ & $\Phi_{\mathrm{F}}(\%)^{a}$ \\
\hline
\end{tabular}




\begin{tabular}{|c|c|c|c|c|}
\hline 4 & 264,368 & $\begin{array}{c}14860 \\
16040\end{array}$ & $-b$ & $-b$ \\
\hline 5 & 250,356 & $\begin{array}{c}19200 \\
39800\end{array}$ & $-b$ & $-b$ \\
\hline 6 & 527 & 70350 & 544 & 7 \\
\hline \multicolumn{5}{|c|}{$\begin{array}{l}{ }^{a} \text { determined in PBS at } 25{ }^{\circ} \mathrm{C} \text { using rhodamine } 6 \mathrm{G}\left(\Phi_{\mathrm{F}}=92 \% \text { in water, } \mathrm{E}\right. \\
470 \mathrm{~nm}) \text { as a standard } 23 \text {. }{ }^{b} \text { non-fluorescent. }\end{array}$} \\
\hline
\end{tabular}

The UV-visible absorption spectrum of 6 displays a maximum at $527 \mathrm{~nm}\left(\varepsilon=70350 \mathrm{M}^{-1} \mathrm{~cm}^{-1}\right)$ and the emission spectrum shows a peak maximum at $544 \mathrm{~nm}\left(\Phi_{\mathrm{F}}=7 \%\right)$. Interestingly, a perfect matching between the absorption and excitation spectra is observed (see Fig. S2), supporting the lack of H-type aggregates under simulated physiological conditions. These photophysical studies show that the enzymatic cleavage of fluorogenic probes $\mathbf{4}$ and $\mathbf{5}$ and subsequent cyclisation-aromatisation process would produce a strong green-yellow fluorescence signal centered at $545 \mathrm{~nm}$.

Fluorescence-based in vitro assays were performed with commercial enzymes (PGA from Escherichia coli and LAP microsomal from porcine kidney) through time-course measurements (Fig. 2A and Fig. S4-S9). The first tests were conducted on the LAP-sensitive probe $\mathbf{5}$ and had confirmed our starting hypothesis related to in situ pyronin formation triggered by protease. Indeed, a significant and gradual increase of green-yellow fluorescence intensity at $545 \mathrm{~nm}$ (Ex. $525 \mathrm{~nm}$ ) was observed when 5 was incubated with LAP at $37^{\circ} \mathrm{C}$ for $14 \mathrm{~h}$. In contrast, without addition of LAP, probe $\mathbf{5}$ displayed minor fluorescence change under the same conditions (diminished by 17-fold compared to the fluorescence level reached with LAP). The slight instability of $\mathbf{5}$ at physiological $\mathrm{pH}$ may well stem from hydrolysis of its anilinamide bond, more reactive than an alkyl counterpart. This non-specific fluorescence signal could be completely suppressed by implementing a dual-reactable strategy. ${ }^{24}$ In an attempt to accelerate the fluorogenic activation kinetics of probe $\mathbf{5}$, two other aq. buffers at acidic and basic $\mathrm{pH}$ respectively (acetate buffer, $100 \mathrm{mM}, \mathrm{pH} 5.6$ and borate buffer, $100 \mathrm{mM}, \mathrm{pH}$ 8.6) were assessed. In both cases, a lower fluorescence end-point value was obtained than that achieved in PB, suggesting the less efficiency of LAP at acidic $\mathrm{pH}$ and the ineffectiveness of cylisation at basic $\mathrm{pH}$. However, the shape of kinetic curve obtained at $\mathrm{pH} 5.6$ has drawn our attention specifically. Indeed, a curved line was observed that can be interpreted as follows : over a period of time of ca. $2 \mathrm{~h}$, the low slope of the curve was not constant and slowly/gradually increased, suggesting a less effective hydrolysis of $\mathbf{5}$ by the protease (LAP is known to be less efficient at this tested $\mathrm{pH})^{25}$. Thereafter, the slope was constant and the fastest kinetics was in agreement with the positive impact of acidic $\mathrm{pH}$ on cyclisation/aromatisation domino process.
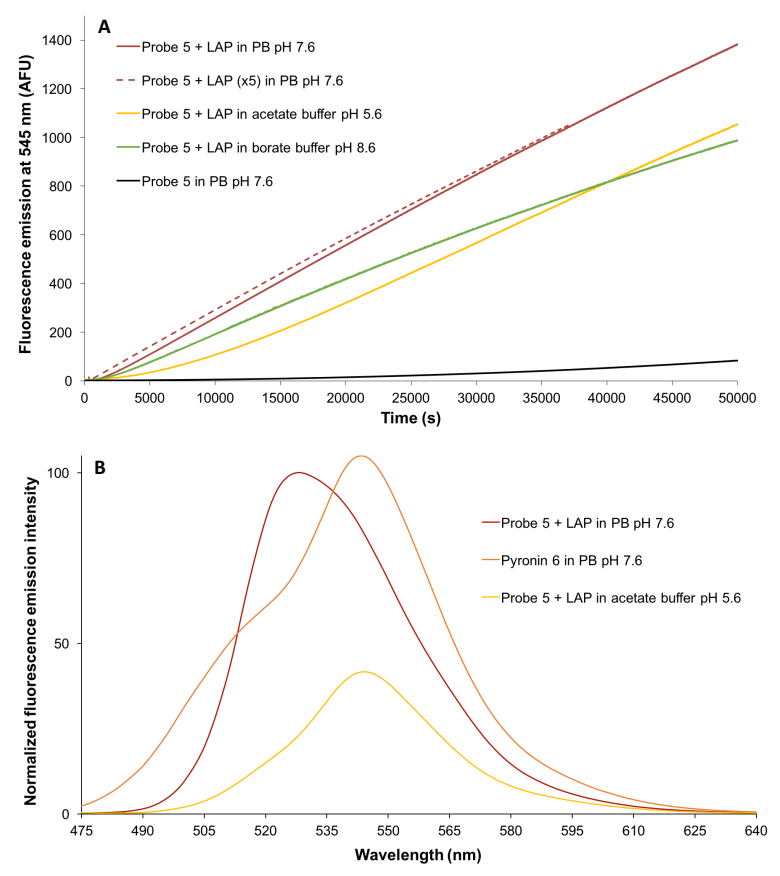

Fig. 2 (A) Time-dependant changes in the green-yellow fluorescence intensity (Ex./Em. 525/545 nm, bandwidth $5 \mathrm{~nm}$ ) of fluorogenic probe 5 (concentration: $1.0 \mu \mathrm{M})$ in the presence of LAP $\left(2 \times 10^{-3} \mathrm{U}\right.$ solid lines and $10^{-2} \mathrm{U}$ for dotted line) in aq. buffers at $37^{\circ} \mathrm{C}$; (B) Fluorescence emission spectra (Ex. $460 \mathrm{~nm}$, bandwidth $5 \mathrm{~nm}$ ) of selected enzymatic reaction mixtures after $24 \mathrm{~h}$ of incubation at $37{ }^{\circ} \mathrm{C}$ and authentic sample of pyronin 6 at the same concentration $(1.0 \mu \mathrm{M})$. Please note: blue-shifted emission curve obtained for reaction with $L A P$ in $P B$ at $37{ }^{\circ} \mathrm{C}$ was explained by the formation of $6-\mathrm{N}$-ethylamino-3H-xanthen-3-imine resulting from dealkylation of in situ generated pyronin 6 .

Considering the more robustness of the PGA enzyme (compared to LAP) under these mild acidic conditions ${ }^{26}$, further tests on the PGA-sensitive probe $\mathbf{4}$ were then performed to validate this hypothesis (see Fig. S4, S5 and S9). The results were clear, at acidic $\mathrm{pH}$ a better fluorogenic response was achieved which indicated a positive action of protons in the mechanism leading to the formation of the fluorescent pyronin core after enzymatic cleavage of the amide bond. However, a new interrogation had emerged concerning the lower levels of fluorescence reached upon enzymatic activation of the PGA-sensitive probe compared to LAP-sensitive probe. To clarify this point, additives found in the commercial sample of LAP (ammonium sulfate and magnesium chloride) were added to PB separately or together, and enzymatic kinetics with PGA were performed. These further analyses clearly highlighted the catalytic role of $\left(\mathrm{NH}_{4}\right)_{2} \mathrm{SO}_{4}$ in the cyclisation reaction (probably as a source of ammonia to generate more reactive imine intermediate) ${ }^{20}$ unlike $\mathrm{MgCl}_{2}$ which seemed to have no impact. Such data could suggest a mechanism involving an imine formation (propably protonated at physiological $\mathrm{pH}$ ) to favor the cyclisation process. Finally, blank experiments without enzyme were performed to ensure that $\left(\mathrm{NH}_{4}\right)_{2} \mathrm{SO}_{4}$ or $\mathrm{MgCl}_{2}$ did not induced the generation of the pyronin dye, and so corroborate that protease is required to obtain a significant fluorescence response. To confirm that the resulting fluorescence emission observed during these timecourse measurements was due to $6-\mathrm{N}, \mathrm{N}$-diethylamino- $3 \mathrm{H}$ - 
xanthen-3-imine dye formed in situ (and to clarify the reason for the blue-shifted shoulder observed in most fluorescence emission spectra recorded after enzymatic kinetics, see Fig. 2B), some enzymatic reaction mixtures were analysed by RP-HPLC coupled with fluorescence detection and synthesised pyronin 6 was used as reference. These chromatographic analyses have confirmed the formation of pyronin dye 6 and clearly revealed the presence of a second fluorescent species in the crude enzymatic reaction which needed to be identified (see Fig. 3 and Fig. S10-S12). Finally, the specificity of the enzymatic cleavage was studied by conducting two control reactions : incubation of PGA-sensitive probe 4 with LAP and incubation of LAP-sensitive probe 5 with PGA respectively. As expected, no significant increase of green-yellow fluorescence at $545 \mathrm{~nm}$ (Ex. $525 \mathrm{~nm}$ ) was observed when 4 was incubated with LAP at $37^{\circ} \mathrm{C}$ for $14 \mathrm{~h}$ (Fig. S13), confirming that this latter protease is not able to cleave the phenylacetamide moiety. Conversely and quite surprisingly, PGA was able to readily activate the LAP fluorogenic substrate 5 because a time-dependant fluorescence response similar to that obtained with LAP was observed (Fig. S14). Further work is currently in progress to gain insights about this novel reactivity of bacterial PGA, already reported for other acylamidases for which aryl amides such as acide paranitroanilides (especially, Leu-pNA) are good substrates. ${ }^{27}$

To achieve this and to gain a better understanding of the sensing mechanism, further enzymatic reactions were performed (at a higher concentration than this used for fluorescence-based assays, $80 \mu \mathrm{M}$ against $1.0 \mu \mathrm{M})$ and periodically analysed by HPLC-MS (see Fig. S15-S17). The first clarification provided by these analyses has concerned the unknown fluorescent species previously noted (vide supra). The peak assigned to this compound $\left(t_{R}=3.4 \mathrm{~min}\right.$ ) was identified as 6- $N$-ethylamino-3H-xanthen-3-imine (MS(ESI+): $\mathrm{m} / z=238.8[\mathrm{M}$ $+\mathrm{H}^{+}$, calcd for $\mathrm{C}_{15} \mathrm{H}_{15} \mathrm{~N}_{2} \mathrm{O}^{+} 239.1$ and UV-vis: $\lambda_{\max }=510 \mathrm{~nm}$ ). Furthermore, its spectral features (absorption and fluorescence emission maxima) were changed (compared to $\mathrm{N}, \mathrm{N}$-diethyl pyronin 6) in a similar way than already reported for rhodamine dyes. ${ }^{28}$ At this stage of the study, the rationale for this $N$ dealkylation process in aq. medium remains unknown. The second valuable information disclosed by the HPLC-MS analyses has concerned the visualisation $\left(t_{R}=4.3 \mathrm{~min}\right)$ and unambiguous identification of key intermediate namely 2-(3aminophenoxy)-4- $N, N$-(diethylamino)benzaldehyde (MS(ESI+): $m / z=285.4[\mathrm{M}+\mathrm{H}]^{+}$, calcd for $\mathrm{C}_{17} \mathrm{H}_{21} \mathrm{~N}_{2} \mathrm{O}_{2}{ }^{+} 285.1$ and UV: $\lambda_{\max }$ $=353 \mathrm{~nm}$ ) which resulted from the enzymatic hydrolysis of the amide bond of probes $\mathbf{4}$ and $\mathbf{5}$. The cyclised xanthydrol derivative $(\mathrm{ROH})$ has the same molecular weight but it was excluded because the chemical equilibrium with the corresponding pyronin 6 is dramatically favored under acidic conditions used for these RP-HPLC analyses $(0.1 \%$ formic acid in water and $\mathrm{CH}_{3} \mathrm{CN}, \mathrm{pH}$ 3.0). ${ }^{29}$ Also worthy of note is that no cyclic product $N$-acylated with the enzyme-labile moiety was detected, thus confirming the need of a protease-mediated cleavage event to trigger the cyclisation/aromatisation domino process leading to in situ generation of fluorescent pyronin dye. All these results allowed us to propose the sensing mechanism depicted in Fig. 4 and that could explain the slow release of pyronin core, the $\mathrm{pH}$ effect and the positive impact of additive $\left(\mathrm{NH}_{4}\right)_{2} \mathrm{SO}_{4}$, leading to the significant fluorescence "turn-on" response of probes $\mathbf{4}$ and $\mathbf{5}$ to proteases.
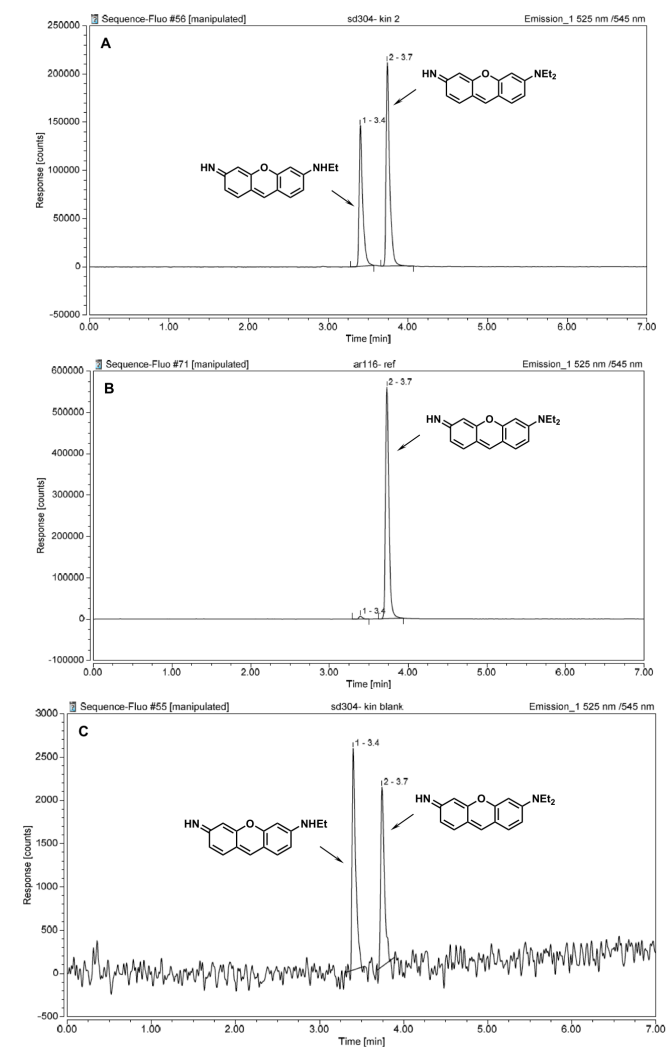

Fig. 3 RP-HPLC elution profiles (fluorescence detection, system $\mathrm{H}$ ) of enzymatic reaction mixture of probe 5 with LAP ( $24 \mathrm{~h}$ of incubation in PB at $37^{\circ} \mathrm{C}$ ) (A), authentic sample of pyronin 6 (B) and probe 5 without LAP (24 h of incubation in $\mathrm{PB}$ at $\left.37^{\circ} \mathrm{C}\right)(\mathrm{C})$. Please note: for all analyses, concentration of injected solution: $1.0 \mu \mathrm{M}$ and injection volume: $10 \mu \mathrm{L}$. Ratio between fluorecence signal detected for enzymatic reaction $(A)$ and control without LAP (C) is ca. 100.

\section{Conclusions}

For the first time, we have demonstrated that the "covalentassembly" probe design principle could be successfully applied to protease sensing in the spectral range $500-600 \mathrm{~nm}$, through in situ generation of unsymmetrical pyronin scaffold. This novel class of activatable fluorescent probes could be a valuable alternative to more conventional FRET-based (or selfquenched) probes and fluorogenic substrates derived from fluorescent anilines (typically pro-fluorophores derived from 7aminocoumarin, rhodamine 110 , cresyl violet and related benzophenoxazines, .... $)^{30}$ even if the reaction rate of cyclisation/aromatisation domino process should be increased. As previously achieved with the rhodamine-based fluorophores, the one-atom replacement of the bridging oxygen atom of caged pyronin precursors by a quaternary carbon ${ }^{31}$ or silicon atom, ${ }^{32,33}$ a pentavalent phosphorus atom (alkyl(diaryl)phosphine oxide or phosphinate moiety) ${ }^{34}$ or a sulfone group ${ }^{35}$ should be an effective way to dramatically shift 
absorption/emission maxima of in situ generated pyronin dye from visible to far-red/NIR region (Fig. 5, top). This will facilitate in vivo molecular imaging of enzyme activity. Further extension of this promising concept to the construction of two-input fluorogenic probes suitable for dual-analyte detection, is currently in progress in our laboratory (Fig. 5, bottom). Indeed, the ability of a fluorescent probe to monitor simultaneously two or more biomarkers for one pathology is particularly attractive for improving medical diagnostics. ${ }^{12,36}$

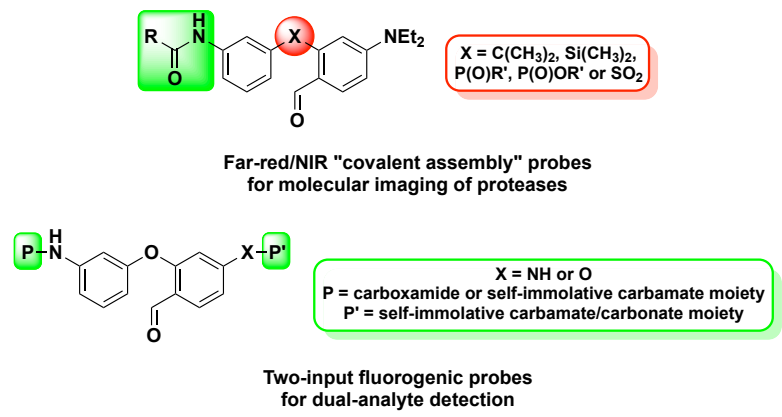

Fig. 5 Possible ways to apply the "covalent-assembly" principle to molecular imaging of proteases (top) and dual-analyte detection (bottom).

\section{Experimental section $\dagger$}

For the preparation of starting benzaldehyde $\mathbf{1}$ and experimental details related to fluorescence-based in vitro assays and HPLC-fluorescence/-MS analyses, see ESI†.

\section{General}

Unless otherwise noted, all commercially available reagents and solvents were used without further purification. TLC were carried out on Merck DC Kieselgel 60 F-254 aluminum sheets. The spots were directly visualised or through illumination with UV lamp ( $\lambda=254 / 365$ $\mathrm{nm}$ ) and/or staining with a phosphomolybdic acid solution (4.8\% wt. in $\mathrm{EtOH})$. Column chromatography purifications were performed on silica gel $(63-200 \mu \mathrm{m})$ from Sigma-Aldrich (technical grade) or on automated flash chromatography purification system (Interchim puriFlash $^{\text {TM }}$ 430). THF and DCM (HPLC-grade) were dried over alumina cartridges using a solvent purification system PureSolv PSMD-5 model from Innovative Technology. TEA was stored over anhydrous $\mathrm{Na}_{2} \mathrm{SO}_{4}$. Anhydrous DMSO and DMF were purchased from Carlo Erba, and stored over $3 \AA$ A molecular sieves. The HPLC-gradient grade acetonitrile $\left(\mathrm{CH}_{3} \mathrm{CN}\right)$ was obtained from Carlo Erba. Formic acid (FA, grade "eluent additive for LC-MS") was provided by SigmaAldrich. Phosphate buffered saline (PBS, $100 \mathrm{mM}+150 \mathrm{mM} \mathrm{NaCl}, \mathrm{PH}$ 7.5), phosphate buffer ( $\mathrm{PB}, 100 \mathrm{mM}, \mathrm{pH} 7.6)$, acetate buffer ( $\mathrm{NaOAc}$, $100 \mathrm{mM}, \mathrm{pH}$ 5.6), borate buffer (100 mM, pH 8.6) and aq. mobilephases for HPLC were prepared using water purified with a PURELAB Ultra system from ELGA (purified to $18.2 \mathrm{M} \Omega . \mathrm{cm}$ ). PGA (from Escherichia coli) was provided by Iris Biotech GmbH (EZ50150, 841 $\mathrm{U} / \mathrm{mL}$ ) and microsomal LAP (from porcine kidney) was supplied by Sigma-Aldrich (L5006, Type IV-S, ammonium sulfate suspension, 10$40 \mathrm{U} / \mathrm{mg}$ protein).

\section{Instrument and methods}

Lyophilisation steps were performed with an Christ Alpha 2-4 LD plus. Centrifugation steps were performed with a Thermo Scientific Espresso Personal Microcentrifuge instrument. ${ }^{1} \mathrm{H}-,{ }^{13} \mathrm{C}$ - and ${ }^{19} \mathrm{~F}-\mathrm{NMR}$ spectra were recorded either on a Bruker Avance 300 or on a Bruker Avance 500 spectrometer. Chemical shifts are expressed in parts per million (ppm) from the residual non-deuterated solvent signal. ${ }^{37} \mathrm{~J}$ values are expressed in $\mathrm{Hz}$. IR spectra were recorded with a Bruker Alpha FT-IR spectrometer equipped with an universal ATR sampling accessory or with a Bruker IR-FT Vector 22 spectrometer equipped with an ATR "Golden Gate" with diamond crystal. The bond vibration frequencies are expressed in reciprocal centimeters $\left(\mathrm{cm}^{-1}\right)$. Elemental analyses (C, H, N, S) were perfomed on a Thermo Scientific Flash EA 1112 instrument. Optical rotation was measured on a PerkinElmer Polarimeter Model 341 with the sodium D-line $(589 \mathrm{~nm})$ at $20{ }^{\circ} \mathrm{C}$ and $[\alpha]_{D}$ values are given in $\mathrm{dm}^{-1} \mathrm{~g}^{-1} \mathrm{~cm}^{3}$. HPLC-MS analyses were performed on a Thermo-Dionex Ultimate 3000 instrument (pump + autosampler) equipped with a diode array detector (Thermo-Dionex DAD 3000-RS) and a MSQ Plus single quadrupole mass spectrometer (LRMS analyses through ESI). HPLC-fluorescence analyses were performed with the same instrument coupled to a RS fluorescence detector (Thermo-Dionex, FLD 3400-RS). Highresolution mass spectra (HRMS) were recorded on a Thermo LTQ Orbitrap XL apparatus equipped with an ESI source. UV-visible spectra were obtained on a Jasco V-630 Bio spectrophotometer by using a rectangular quartz cell (Hellma, 100-QS, $45 \times 12.5 \times 12.5 \mathrm{~mm}$, pathlength $10 \mathrm{~mm}$, chamber volume: $3.5 \mathrm{~mL}$ ). Fluorescence spectroscopic studies (emission/excitation spectra and kinetics) were performed with an Jasco FP-8500 spectrofluorometer (software Spectra Manager) with a standard fluorometer cell (Labbox, LB Q, $10 \mathrm{~mm}$ ). Emission spectra were recorded under the same conditions after excitation at the corresponding wavelength (Ex $/$ Em bandwidth $=5 \mathrm{~nm}$, response $=1 \mathrm{~s}$ and PMT sensitivity $=$ medium). All fluorescence spectra were corrected.

Fluorescence quantum yield of $6-\mathrm{N}, \mathrm{N}$-diethylamino-3H-xanthen-3imine 6 (TFA salt) was measured in PBS at $25^{\circ} \mathrm{C}$ by a relative method using rhodamine $6 \mathrm{G}\left(\Phi_{\mathrm{F}}=92 \%\right.$ in $\left.\mathrm{H}_{2} \mathrm{O}\right)$ as a standard ${ }^{23}$ (for the corresponding $\mathrm{Abs} / \mathrm{Ex} / \mathrm{Em}$ spectra, see Fig. S2). The following equation was used to determine the relative fluorescence quantum yield:

$$
\Phi_{\mathrm{F}}(\mathrm{x})=\left(\mathrm{A}_{\mathrm{S}} / \mathrm{Ax}_{\mathrm{x}}\right)\left(\mathrm{F}_{\mathrm{x}} / \mathrm{F}_{\mathrm{S}}\right)\left(\mathrm{n}_{\mathrm{x}} / \mathrm{n}_{\mathrm{S}}\right)^{2} \Phi_{\mathrm{F}}(\mathrm{s})
$$

where $A$ is the absorbance (in the range of 0.01-0.1 A.U.), $F$ is the area under the emission curve, $\mathrm{n}$ is the refractive index of the solvents (at $25{ }^{\circ} \mathrm{C}$ ) used in measurements, and the subscripts $s$ and $x$ represent standard and unknown, respectively. The following refractive index values are used: 1.333 for $\mathrm{H}_{2} \mathrm{O}$ and 1.337 for PBS.

\section{Automated flash-column chromatography and high-performance liquid chromatography separations}

Several chromatographic systems were used for the analytical experiments (HPLC-MS or HPLC-fluorescence) and the 
purification steps respectively: System $A$ : RP-HPLC (Phenomenex Kinetex $\mathrm{C}_{18}$ column, $2.6 \mu \mathrm{m}, 2.1 \times 50 \mathrm{~mm}$ ) with $\mathrm{CH}_{3} \mathrm{CN}(+0.1 \% \mathrm{FA}$ ) and $0.1 \%$ aq. formic acid (aq. $\mathrm{FA}, \mathrm{pH} 2.7$ ) as eluents [5\% $\mathrm{CH}_{3} \mathrm{CN}(0.1 \mathrm{~min})$ followed by linear gradient from $5 \%$ to $100 \%$ (5 min) of $\mathrm{CH}_{3} \mathrm{CN}$ ] at a flow rate of $0.5 \mathrm{~mL} \mathrm{~min}^{-1}$. UVvisible detection was achieved at 220, 260, 320 and $540 \mathrm{~nm} \mathrm{(+}$ diode array detection in the range $220-700 \mathrm{~nm}$ ). Low resolution ESI-MS detection in the positive/negative mode (full scan, 100700 a.m.u., data type: centroid, needle voltage: $3.0 \mathrm{kV}$, probe temperature: $350{ }^{\circ} \mathrm{C}$, cone voltage: $75 \mathrm{~V}$ and scan time: $1 \mathrm{~s}$ ). System B: System A with UV-visible detection at 220, 260, 500 and $550 \mathrm{~nm}$ (+ diode array detection in the range $220-800 \mathrm{~nm}$ ). Low resolution ESI-MS detection in the positive/negative mode (full scan, 150-1500 a.m.u.). System C: semi-preparative RPHPLC (Thermo BetaBasic- $\mathrm{C}_{18}$ column, $5 \mu \mathrm{m}, 150 \times 30 \mathrm{~mm}$ ) with $\mathrm{CH}_{3} \mathrm{CN}$ and $\mathrm{H}_{2} \mathrm{O}$ as eluents [ $40 \% \mathrm{CH}_{3} \mathrm{CN}$ (5 min), followed by a gradient of $40 \%$ to $55 \% \mathrm{CH}_{3} \mathrm{CN}$ ( $15 \mathrm{~min}$ ), then $55 \%$ to $80 \% \mathrm{CH}_{3} \mathrm{CN}$ (35 min)] at a flow rate of $20.0 \mathrm{~mL} \mathrm{~min}^{-1}$. Dual UV detection was achieved at 260 and $350 \mathrm{~nm}$. System D: semi-preparative RPHPLC (Thermo Betabasic- $\mathrm{C}_{18}$ column, $5 \mu \mathrm{m}, 150 \times 30 \mathrm{~mm}$ ) with $\mathrm{CH}_{3} \mathrm{CN}$ and $\mathrm{H}_{2} \mathrm{O}$ as eluents [ $30 \% \mathrm{CH}_{3} \mathrm{CN}$ (5 min), followed by a gradient of $30 \%$ to $60 \% \mathrm{CH}_{3} \mathrm{CN}(20 \mathrm{~min})$, then $60 \%$ to $95 \% \mathrm{CH}_{3} \mathrm{CN}$ (35 min)] at a flow rate of $20.0 \mathrm{~mL} \mathrm{~min}^{-1}$. Dual UV detection was achieved at 260 and $350 \mathrm{~nm}$. System E: semi-preparative RPHPLC (SiliCycle SiliaChrom $\mathrm{C}_{18}$ column, $10 \mu \mathrm{m}, 20 \times 250 \mathrm{~mm}$ ) with $\mathrm{CH}_{3} \mathrm{CN}$ and aq. $0.1 \%$ TFA (pH 2.0) as eluents [0\% $\mathrm{CH}_{3} \mathrm{CN}(5$ min), followed by a gradient of $0 \%$ to $15 \% \mathrm{CH}_{3} \mathrm{CN}(10 \mathrm{~min}$ ), then $15 \%$ to $\left.60 \% \mathrm{CH}_{3} \mathrm{CN}(60 \mathrm{~min})\right]$ at a flow rate of $20.0 \mathrm{~mL} \mathrm{~min}-1$. Quadruple UV-vis detection was achieved at 280, 350, 425 and $530 \mathrm{~nm}$. System F: semi-preparative RP-HPLC (Thermo Hypersil GOLD $\mathrm{C}_{18}$ column, $5 \mu \mathrm{m}, 10 \times 250 \mathrm{~mm}$ ) with $\mathrm{CH}_{3} \mathrm{CN}$ and aq. $0.1 \%$ TFA ( $\mathrm{pH} 2.0$ ) as eluents [0\% $\mathrm{CH}_{3} \mathrm{CN}(5 \mathrm{~min})$, followed by a gradient of $0 \%$ to $15 \% \mathrm{CH}_{3} \mathrm{CN}(10 \mathrm{~min})$, then $15 \%$ to $75 \% \mathrm{CH}_{3} \mathrm{CN}$

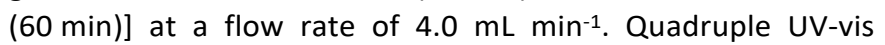
detection was achieved at 280, 350, 425 and $530 \mathrm{~nm}$. System G: System A with triple UV-visible detection which was achieved at 260, 350 and $525 \mathrm{~nm}$ (+ diode array detection in the range 220$700 \mathrm{~nm}$ ). System $\mathrm{H}$ : RP-HPLC-fluorescence (Phenomenex Kinetex $\mathrm{C}_{18}$ column, $2.6 \mu \mathrm{m}, 2.1 \times 50 \mathrm{~mm}$ ) with same eluents and gradient as System A. Fluorescence detection was achieved at $45{ }^{\circ} \mathrm{C}$ at the following Ex./Em. channels: 525/545 nm and 510/530 nm (sensitivity: 1, PMT 1, filter wheel: auto).

One chromatographic system was used for the purification on an automated flash chromatography purification system (Interchim puriFlash ${ }^{\mathrm{Tm}}$ 430): System I: $\mathrm{RP}^{-\mathrm{C}_{18}}$ cartridge (SiliCycle SiliaSep ${ }^{\mathrm{TM}} \mathrm{C}_{18}, 40 \mathrm{~g}$ ) with $\mathrm{CH}_{3} \mathrm{CN}$ and aq. $0.1 \%$ TFA (pH 2.0) as eluents $\left[0 \% \mathrm{CH}_{3} \mathrm{CN}(1.5 \mathrm{CV})\right.$, followed by a gradient of $0 \%$ to $10 \%$ $\mathrm{CH}_{3} \mathrm{CN}(2 \mathrm{CV})$, then $10 \%$ to $70 \% \mathrm{CH}_{3} \mathrm{CN}(10 \mathrm{CV})$ ] at a flow rate of $26 \mathrm{~mL} \mathrm{~min}^{-1}$. Triple UV-vis detection was achieved at 250, 500 and $550 \mathrm{~nm}$.

3-(Phenylacetamide)iodobenzene (2). To a solution of phenylacetic acid $\left(1.5 \mathrm{~g}, 11.0 \mathrm{mmol}, 1\right.$ equiv.) in dry DCM $(10 \mathrm{~mL})$ was added $\mathrm{SOCl}_{2}$ (1.20 mL, $16.5 \mathrm{mmol}, 1.5$ equiv.) and dry DMF ( $84 \mu \mathrm{L}, 1.1 \mathrm{mmol}, 0.1$ equiv.) and the resulting reaction mixture stirred at RT for $1 \mathrm{~h}$. Thereafter, solvent was removed in vacuo to give $\mathrm{PhAcCl}$ which was kept under an Ar athmosphere and then slowly added to a mixture of 3-iodoaniline ( $2 \mathrm{~g}, 9.13 \mathrm{mmol}, 0.8$ equiv.) and TEA (1.53 mL, 11.0 mmol, 1 equiv.) in dry THF ( $35 \mathrm{~mL})$ at $0{ }^{\circ} \mathrm{C}$ under an Ar athmosphere. The reaction mixture was strirred for $2 \mathrm{~h} 30$ between $0{ }^{\circ} \mathrm{C}$ and RT and then concentrated under reduced pressure. The residue was retaken in EtOAc, washed with deionised water, aq. $5 \% \mathrm{~K}_{2} \mathrm{CO}_{3}$ and brine and then dried over anhydrous $\mathrm{MgSO}_{4}$, filtered, and concentrated to afford the product 2 as brown solid $(2.85 \mathrm{~g}$, yield 90\%). IR (ATR): $v=$ $3249,3026,2918,1653,1575,1518,1470,1395,1343,1281,1238$, $1192,1173,1090,1060,1028,994,974,881,861,768,716 \mathrm{~cm}^{-1} ;{ }^{1} \mathrm{H}$ NMR (300 MHz, DMSO- $d_{6}$ ): $\delta=3.63\left(\mathrm{~s}, 2 \mathrm{H}, \mathrm{CH}_{2}-\mathrm{PhAc}\right), 7.10$ (t, $J=8$ $\mathrm{Hz}, 1 \mathrm{H}, \underline{H}-\mathrm{Ar}$ ), 7.23-7.34 (m, $5 \mathrm{H}, \underline{H}-\mathrm{PhAc}), 7.40$ (bd, J= $7.8 \mathrm{~Hz}, 1 \mathrm{H}, \underline{H}-$ Ar), 7.53 (bd, $J=8.1 \mathrm{~Hz}, 1 \mathrm{H}, \underline{H}-\mathrm{Ar}), 8.13(\mathrm{t}, J=1.8 \mathrm{~Hz}, 1 \mathrm{H}, \underline{H}-\mathrm{Ar}$ ), $10.26(\mathrm{~s}, 1 \mathrm{H}, \mathrm{N} \underline{H}) \mathrm{ppm} ;{ }^{13} \mathrm{C} \mathrm{NMR}\left(126 \mathrm{MHz}, \mathrm{DMSO}-d_{6}\right): \delta=43.3,94.5$, $118.2,126.6,127.3,128.3$ (2 C), 129.1 (2 C), 130.8, 131.7, 135.6, 140.6, 169.3 ppm; HPLC (system A): $t_{R}=4.9$ min (purity $93 \%$ at 260 $\mathrm{nm})$; LRMS (ESI+, recorded during RP-HPLC analysis): $m / z 338.0[\mathrm{M}+$ $\mathrm{H}]^{+}(60)$ and $379.0\left[\mathrm{M}+\mathrm{H}+\mathrm{CH}_{3} \mathrm{CN}\right]^{+}(100)$, calcd for $\mathrm{C}_{14} \mathrm{H}_{13} \mathrm{INO} \mathrm{NO}^{+} 338.0$; LRMS (ESI-, recorded during RP-HPLC analysis): $\mathrm{m} / z 335.9$ [M - H] (100) and 382.1 [M - H + FA] $]^{-}$(25), calcd for $\mathrm{C}_{14} \mathrm{H}_{11} \mathrm{INO}^{-} 336.0$.

Boc-L-leucine meta-iodophenylamide (3). To a stirred solution of Boc-L-leucine (1.5 g, $6.45 \mathrm{mmol}, 1$ equiv.) in dry THF $(20 \mathrm{~mL})$ at -20 ${ }^{\circ} \mathrm{C}, \mathrm{N}$-Methylmorpholine (NMM, $715 \mu \mathrm{L}, 6.45 \mathrm{mmol}, 1$ equiv.) and isobutyl chloroformate $(840 \mu \mathrm{L}, 6.45 \mathrm{mmol}, 1$ equiv.) were successively added. After an activation period of $25 \mathrm{~min}, 3-$ iodoaniline (1.835 g, $6.45 \mathrm{mmol}, 1.3$ equiv.) in dry THF $(5 \mathrm{~mL})$ was slowly added to the above solution. The reaction mixture was stirred for $3 \mathrm{~h}$ between $-5^{\circ} \mathrm{C}$ and $0{ }^{\circ} \mathrm{C}$. Thereafter, the resulting solution was quenched by adding $10 \mathrm{~mL}$ of aq. saturated $\mathrm{NaHCO}_{3}$ and then was extracted with DCM $(3 \times 50 \mathrm{~mL})$. The organic layers were combined and washed with aq. $1 \mathrm{~N} \mathrm{HCl}$ and brine, dried over anhydrous $\mathrm{MgSO}_{4}$, filtered, and concentrated to afford the product 3 as white solid (1.946 g, yield 70\%). IR (ATR): $v=3284,2957,1663,1586,1526,1472$, $1416,1391,1365,1289,1244,1160,1047,1023,993,877,773 \mathrm{~cm}^{-1}$; ${ }^{1} \mathrm{H}$ NMR (300 MHz, DMSO- $\left.d_{6}\right): \delta=0.88\left(\mathrm{~m}, 6 \mathrm{H}, \mathrm{C}_{3}\right.$-Leu), 1.20-1.75 (m, $12 \mathrm{H}, \mathrm{C}_{3}-\mathrm{Boc}$ and $\mathrm{C}_{2}$ - $\underline{\mathrm{C}} \underline{\mathrm{H}}$-Leu), 4.08 (m, $1 \mathrm{H}, \underline{\mathrm{C}} \underline{\mathrm{H}}$-NH-Leu), 7.09 (m, $2 \mathrm{H}, \underline{H}-\mathrm{Ar}$ ), 7.39 (d, J=8.4 Hz, $1 \mathrm{H}, \underline{H}-\mathrm{Ar}), 7.55$ (d, J = 8.1 Hz, $1 \mathrm{H}$, $\underline{H}$-Ar), 8.11 (bs, $1 \mathrm{H}, \underline{\mathrm{N}} \underline{\mathrm{H}}$-Boc), 10.05 (s, $1 \mathrm{H}, \mathrm{N} \underline{H}) \mathrm{ppm} ;{ }^{13} \mathrm{C}$ NMR (126 $\left.\mathrm{MHz}, \mathrm{DMSO}-d_{6}\right): \delta=21.5,22.9,24.3,28.2$ (3 C, $\underline{\mathrm{C}}_{3}-\mathrm{Boc}$ ), 40.4, 53.5, 78.0, 94.4, 118.4, 127.4, 130.7, 131.7, 140.4, 155.4, 172.0 ppm; HPLC (system A): $t_{R}=5.4$ min (purity $99 \%$ at $260 \mathrm{~nm}$ ); LRMS (ESI+, recorded during RP-HPLC analysis): $m / z 433.1[\mathrm{M}+\mathrm{H}]^{+}(60)$ and 376.7 [M - tBu $+\mathrm{H}]^{+}(100)$, calcd for $\mathrm{C}_{17} \mathrm{H}_{26} \mathrm{IN}_{2} \mathrm{O}_{3}{ }^{+} 433.1$; LRMS (ESI-, recorded during RP-HPLC analysis): $m / z 430.9$ [M - H] $]^{-}$(70) and 476.9 [M - H + FA] $]^{-}(45)$, calcd for $\mathrm{C}_{17} \mathrm{H}_{24} \mathrm{IN}_{2} \mathrm{O}_{3}-431.1$.

PGA-sensitive probe (4). A mixture of benzaldehyde 1 (400 mg, 2.07 mmol, 1.2 equiv.), iodoaryl derivative $2(582 \mathrm{mg}, 1.73 \mathrm{mmol}, 1$ equiv.), finely ground $\mathrm{K}_{3} \mathrm{PO}_{4}$ (732 mg, $3.45 \mathrm{mmol}, 2$ equiv.), Cul (33 $\mathrm{mg}, 0.17 \mathrm{mmol}, 0.1$ equiv.) and picolinic acid ( $43 \mathrm{mg}, 0.35 \mathrm{mmol}, 0.2$ equiv.) in dry DMSO $(4.2 \mathrm{~mL})$ was heated in a sealed tube at $130^{\circ} \mathrm{C}$ overnight. The reaction was checked for completion by HPLC (system A) and quenched with $10 \mathrm{~mL}$ of deionized water. Then, the resuting mixture was extracted with EtOAc, washed with brine, dried over anhydrous $\mathrm{Na}_{2} \mathrm{SO}_{4}$, filtered and concentrated under reduced pressure. The residue was purified by flash-column chromatography over silica gel (cartridge $40 \mathrm{~g}$ ) using an automated purification system (Interchim puriFlash ${ }^{\text {TM }} 430$ ), eluted with a linear gradient of EtOAc in 
DCM (from $0 \%$ to $40 \%$ ) to get bis-aryl ether 4 as brown solid $(380 \mathrm{mg}$, yield 54\%). Please note: A second purification by semi-preparative HPLC (system $C, t_{R}=28.0-30.9 \mathrm{~min}$ ) can afford a pale yellow solid after freeze-drying. IR (ATR): $v=3289,2971,1664,1590,1522,1484$, 1436, 1406, 1393, 1353, 1262, 1196, 1149, 1097, 1076, 1001, 983, 869, 778, $719 \mathrm{~cm}^{-1} ;{ }^{1} \mathrm{H}$ NMR ( $300 \mathrm{MHz}$, DMSO- $d_{6}$ ): $\delta=1.04$ (t, $J=7.0$ $\mathrm{Hz}, 6 \mathrm{H}, \mathrm{C}_{3}-\mathrm{Et}$ ), 3.34 (mask by $\mathrm{H}_{2} \mathrm{O}$ signal) (q, $J=7.0 \mathrm{~Hz}, 4 \mathrm{H}, \mathrm{CH}_{2}-\mathrm{Et}$ ), 3.61 (s, $\left.2 \mathrm{H}, \underline{C}_{2}-\mathrm{PhAc}\right), 6.11$ (d, J = 2.4 Hz, $1 \mathrm{H}, \underline{H}-\mathrm{Ar}$ ), 6.60 (dd, $J=2.1$ $\mathrm{Hz}, J=9.0 \mathrm{~Hz}, 1 \mathrm{H}, \underline{H}-\mathrm{Ar}), 6.74(\mathrm{dq}, J=1.5 \mathrm{~Hz}, J=2.1 \mathrm{~Hz}, J=7.8 \mathrm{~Hz}, 1$ $\mathrm{H}, \underline{H}-\mathrm{Ar}), 7.22-7.40(\mathrm{~m}, 8 \mathrm{H}, \underline{H}-\mathrm{Ar}$ and $\underline{H}-\mathrm{PhAc}), 7.65(\mathrm{~d}, J=9.0 \mathrm{~Hz}, 1 \mathrm{H}$, $\underline{H}$-Ar), 9.89 (s, $1 \mathrm{H}, \underline{H}$-formyl), 10.26 (s, $1 \mathrm{H}, \mathrm{N} \underline{H}$ ) ppm; ${ }^{13} \mathrm{C}$ NMR (126 $\left.\mathrm{MHz}, \mathrm{DMSO}-d_{6}\right): \delta=12.2$ (2 C, $\left.\underline{\mathrm{CH}}_{3}-\mathrm{Et}\right), 43.3,44.1$ (2 C, $\left.\underline{\mathrm{CH}}_{2}-\mathrm{Et}\right), 100.6$, $107.7,108.2,112.5,113.8,115.2,126.5,128.2$ (2 C), 129.0 (2 C), 130.0, 130.1, 135.8, 140.7, 153.4, 157.6, 160.4, 169.2, 185.1 ppm; HPLC (system A): $t_{R}=5.2$ min (purity $99 \%$ at $260 \mathrm{~nm}$ ); LRMS (ESI+, recorded during RP-HPLC analysis): $m / z 403.1\left[\mathrm{M}+\mathrm{H}^{+}(100)\right.$, calcd for $\mathrm{C}_{25} \mathrm{H}_{27} \mathrm{~N}_{2} \mathrm{O}_{3}{ }^{+}$403.2; LRMS (ESI-, recorded during RP-HPLC analysis): $m / z 400.8$ [M - H]- (100) and 447.0 [M - H + FA] ${ }^{-}(60)$, calcd for $\mathrm{C}_{25} \mathrm{H}_{25} \mathrm{~N}_{2} \mathrm{O}_{3}{ }^{-}$401.2; HRMS (ESI+): $\mathrm{m} / z 425.18194[\mathrm{M}+\mathrm{Na}]^{+}$, calcd for $\mathrm{C}_{25} \mathrm{H}_{26} \mathrm{~N}_{2} \mathrm{O}_{3} \mathrm{Na}^{+}$425.18356; UV-vis: $\lambda_{\max }(\mathrm{PBS}) / \mathrm{nm} 264$ and 368 ( $\varepsilon / \mathrm{dm}^{3} \mathrm{~mol}^{-1} \mathrm{~cm}^{-1} 14860$ and 16040 ).

LAP-sensitive probe (5). A mixture of benzaldehyde 1 (76 $\mathrm{mg}, 0.39$ mmol, 1.7 equiv.), iodoaryl derivative $3(100 \mathrm{mg}, 0.23 \mathrm{mmol}, 1$ equiv.), finely ground $\mathrm{K}_{3} \mathrm{PO}_{4}$ (93 $\mathrm{mg}, 0.44 \mathrm{mmol}, 1.9$ equiv.), Cul (5 $\mathrm{mg}, 0.02 \mathrm{mmol}, 0.1$ equiv.) and picolinic acid $(6 \mathrm{mg}, 0.04 \mathrm{mmol}, 0.2$ equiv.) in dry DMSO $(1 \mathrm{~mL})$ was heated in a sealed tube at $90{ }^{\circ} \mathrm{C}$ overnight. The reaction was checked for completion by HPLC (system A) and quenched with $10 \mathrm{~mL}$ of deionised water. Then, the resulting mixture was extracted with DCM, washed with aq. $1 \mathrm{~N} \mathrm{HCl}$, dried over anhydrous $\mathrm{Na}_{2} \mathrm{SO}_{4}$, filtered and concentrated under reduced pressure. The residue was retaken in DCM $(400 \mu \mathrm{L})$ and TFA $(700 \mu \mathrm{L}$, 40 equiv.) was added at $0{ }^{\circ} \mathrm{C}$. The resulting reaction mixture was stirred at $0{ }^{\circ} \mathrm{C}$ for $20 \mathrm{~min}$, diluted in $\mathrm{CH}_{3} \mathrm{CN}(5 \mathrm{~mL})$ and evaporated under vacuum. The resulting oily residue was purified by semipreparative RP-HPLC (system $D, t_{R}=18.0-22.0 \mathrm{~min}$ ). The TFA salt of desired LAP-sensitive probe 5 was recovered as white powder (13 $\mathrm{mg}$, yield 11\%). IR (ATR): $v=2970,1669,1591,1524,1485,1441$, $1393,1355,1267,1199,1135,1100,977,834,798,721 \mathrm{~cm}^{-1} ;{ }^{1} \mathrm{H}$ NMR ( $300 \mathrm{MHz}, \mathrm{DMSO}-d_{6}$ ): $\delta=0.90$ (d, $J=3.6 \mathrm{~Hz}, 6 \mathrm{H}, \underline{\mathrm{C}}_{3}$-Leu), 1.06 (t, $J=$ $7.2 \mathrm{~Hz}, 6 \mathrm{H}, \mathrm{CH}_{3}-\mathrm{Et}$ ), 1.63 (bd, $3 \mathrm{H}, \mathrm{CH}-\mathrm{CH}_{2}$-Leu), 3.37 (mask by $\mathrm{H}_{2} \mathrm{O}$ signal) (q, $J=6.9 \mathrm{~Hz}, 4 \mathrm{H}, \mathrm{C}_{2}-\mathrm{Et}$ ), 3.88 (bs, $1 \mathrm{H}, \underline{\mathrm{C}}-\mathrm{NH}_{2}-\mathrm{Leu}$ ), 6.16 (d, $J=2.4 \mathrm{~Hz}, 1 \mathrm{H}, \underline{H}-\mathrm{Ar}$ ), 6.64 (dd, $J=2.1 \mathrm{~Hz}, J=9.0 \mathrm{~Hz}, 1 \mathrm{H}, \underline{H}-\mathrm{Ar}$ ), 6.74 (m, $1 \mathrm{H}, \underline{H}-\mathrm{Ar}), 7.34-7.40$ (m, $3 \mathrm{H}, \underline{H}-\mathrm{Ar}), 7.67$ (d, J=9.0 Hz, $1 \mathrm{H}, \underline{H}-\mathrm{Ar}$ ), 8.24 (bs, $2 \mathrm{H}, \mathrm{N}_{2}$-Leu), 9.87 (s, $1 \mathrm{H}, \underline{H}$-formyl), 10.60 (s, $1 \mathrm{H}, \mathrm{N} \underline{H}$ ) ppm; ${ }^{13} \mathrm{C}$ NMR (126 MHz, DMSO- $d_{6}$ ): $\delta=12.2\left(2 \mathrm{C}, \underline{\mathrm{C}} \mathrm{H}_{3}-\mathrm{Et}\right), 21.8,22.6,23.7$, 39.5 (1C, masked by DMSO signal), 44.2 (2 C, $\mathrm{CH}_{2}-\mathrm{Et}$ ), 51.8, 101.1, 108.0, 108.2, 113.4, 114.1, 115.3, 130.3, 130.4, 139.5, 153.4, 158.0, 160.0, 168.0, $185.2 \mathrm{ppm} ;{ }^{19} \mathrm{~F} \mathrm{NMR}\left(470 \mathrm{MHz}, \mathrm{DMSO}-d_{6}\right): \delta=-73.7$ (s, $3 \mathrm{~F}, \mathrm{C} \underline{F}_{3}$-TFA); HPLC (system A): $t_{\mathrm{R}}=4.0 \mathrm{~min}$ (purity $93 \%$ at $260 \mathrm{~nm}$ ); LRMS (ESI+, recorded during RP-HPLC analysis): $m / z 398.1[\mathrm{M}+\mathrm{H}]^{+}$ (100), calcd for $\mathrm{C}_{23} \mathrm{H}_{32} \mathrm{~N}_{3} \mathrm{O}_{3}+398.2$; LRMS (ESI-, recorded during RPHPLC analysis): $m / z 395.9$ [M - H] $]^{-}(100)$ and 442.1 [M + H - FA] $]^{-}(40)$, calcd for $\mathrm{C}_{23} \mathrm{H}_{30} \mathrm{~N}_{3} \mathrm{O}_{3}-396.2$; HRMS (ESI+): $\mathrm{m} / \mathrm{z} 398.24329[\mathrm{M}+\mathrm{H}]^{+}$, calcd for $\mathrm{C}_{23} \mathrm{H}_{32} \mathrm{~N}_{3} \mathrm{O}_{3}+398.24382$ and $420.22500[\mathrm{M}+\mathrm{Na}]^{+}$, calcd for $\mathrm{C}_{23} \mathrm{H}_{31} \mathrm{~N}_{3} \mathrm{O}_{3} \mathrm{Na}^{+}$420.22576; Elemental anal.: Found $\mathrm{C}, 57.1 ; \mathrm{H}, 6.5 ; \mathrm{N}$, 7.8. $\mathrm{C}_{23} \mathrm{H}_{31} \mathrm{~N}_{3} \mathrm{O}_{3}$. $1.2 \mathrm{CF}_{3} \mathrm{CO}_{2} \mathrm{H}$ requires $\mathrm{C}, 57.1 ; \mathrm{H}, 6.1 ; \mathrm{N}, 7.9 \%$; UV- vis: $\lambda_{\max }(\mathrm{PBS}) / \mathrm{nm} 250$ and $356\left(\varepsilon / \mathrm{dm}^{3} \mathrm{~mol}^{-1} \mathrm{~cm}^{-1} 19200\right.$ and 39800$)$; $[\alpha]_{D}+39^{\circ}$ (c 0.2 in $\mathrm{CH}_{3} \mathrm{OH}$ ).

6- $\mathrm{N}, \mathrm{N}$-Diethylamino-3H-xanthen-3-imine (6). A mixture of benzaldehyde 1 (100 mg, $0.52 \mathrm{mmol}, 1$ equiv.) and 3-aminophenol (59 mg, $0.54 \mathrm{mmol}, 1$ equiv.) in TFA (3.35 mL) was heated under reflux for $24 \mathrm{~h}$. The reaction was checked for completion by HPLC (system A). To favor dehydration process (leading to desired pyronin), methanesulfonic acid ( $\mathrm{MsOH}, 0.5 \mathrm{~mL}$ ) was added and the reaction mixture was stirred under reflux for further $6 \mathrm{~h}$. Thereafter, the mixture was evaporated under reduced pressure. The resulting residue was dissolved in a mixture of aq. $0.1 \%$ TFA and $\mathrm{CH}_{3} \mathrm{OH}(1: 1$, $\mathrm{v} / \mathrm{v}, 5 \mathrm{~mL}$ ) and pre-purified by automated flash-column chromatography over reversed-phase $C_{18}$ silica gel (system I). The product-containing fractions were lyophilised and the resulting amorphous powder was purified twice by semi-preparative RP-HPLC (system $\mathrm{E}, t_{\mathrm{R}}=41.0-51.0 \mathrm{~min}$ and system $\mathrm{F}, t_{\mathrm{R}}=34.6-37.2 \mathrm{~min}$ ). The TFA salt of desired pyronin 6 was recovered as red amorphous powder (6 mg, 2\%). Please note: despite two RP-HPLC purifications, the product remains contaminated with a minor amount of starting aldehyde (10\%). IR (ATR): $v=3334$ (broad), 3109 (broad), 2923, 2855, 2740, 1650 (broad), 1572 (broad), 1488, 1429, 1381, 1336, 1274, $1149,1118,1072,1008,967,822,796,737,703 \mathrm{~cm}^{-1} ;{ }^{1} \mathrm{H}$ NMR (500 $\mathrm{MHz}, \mathrm{CD}_{3} \mathrm{OD}$ ): $\delta=1.32$ (t, $J=7.0 \mathrm{~Hz}, 6 \mathrm{H}, \mathrm{C}_{3}-\mathrm{Et}$ ), 3.70 (q, $J=7.0 \mathrm{~Hz}$, $4 \mathrm{H}, \underline{\mathrm{C}}_{2}-\mathrm{Et}$ ), 6.77 (bd, $\left.J=1.0 \mathrm{~Hz}, 1 \mathrm{H}, \underline{H}-\mathrm{Ar}\right), 6.92(\mathrm{bd}, J=2.0 \mathrm{~Hz}, 1 \mathrm{H}$, $\underline{H}$-Ar), 6.95 (dd, J = $2.0 \mathrm{~Hz}, J=9.0 \mathrm{~Hz}, 1 \mathrm{H}, \underline{H}-\mathrm{Ar}$ ), 7.18 (dd, $J=2.0 \mathrm{~Hz}, J$ $=9.0 \mathrm{~Hz}, 1 \mathrm{H}, \underline{H}-\mathrm{Ar}$ ), 7.72 (d, J=9.0 Hz, $1 \mathrm{H}, \underline{H}-\mathrm{Ar}), 7.80$ (d, $J=9.0 \mathrm{~Hz}$, $1 \mathrm{H}, \underline{H}-\mathrm{Ar}$ ), 8.55 (s, $1 \mathrm{H}, \underline{H}-\mathrm{Ar}) \mathrm{ppm} ;{ }^{13} \mathrm{C} \mathrm{NMR}\left(126 \mathrm{MHz}, \mathrm{CD}_{3} \mathrm{OD}\right): \delta=$ 12.9 (2 C, $\left.\underline{\mathrm{CH}}_{3}-\mathrm{Et}\right), 47.0$ (2 C, $\left.\underline{\mathrm{CH}}_{2}-\mathrm{Et}\right), 97.3,98.6,115.5,115.7,116.0$, 118.0, 134.8, 135.2, 147.6, 157.9, 159.8, 160.3, 162.1 ppm; ${ }^{19} \mathrm{~F} N \mathrm{NMR}$ (470 MHz, CD 30 D): $\delta=-76.9$ (s, $3 \mathrm{~F}, \mathrm{C}_{3}-\mathrm{TFA}$ ); HPLC (system B): $t_{\mathrm{R}}=$ $3.7 \mathrm{~min}$ (purity $92 \%$ at $260 \mathrm{~nm}$ and $99 \%$ at $500 \mathrm{~nm}$ ); LRMS (ESI+, recorded during RP-HPLC analysis): $m / z 267.0[\mathrm{M}+\mathrm{H}]^{+}(100)$, calcd for $\mathrm{C}_{17} \mathrm{H}_{19} \mathrm{~N}_{2} \mathrm{O}^{+}$267.1; Elemental anal.: Found $\mathrm{C}, 56.6 ; \mathrm{H}, 5.7 ; \mathrm{N}, 6.8$. $\mathrm{C}_{17} \mathrm{H}_{18} \mathrm{~N}_{2} \mathrm{O} .1 .33 \mathrm{CF}_{3} \mathrm{CO}_{2} \mathrm{H}$ requires $\mathrm{C}, 56.5 ; \mathrm{H}, 4.7 ; \mathrm{N}, 6.7 \%$. UV-vis: $\lambda_{\max }(\mathrm{PBS}) / \mathrm{nm} 527\left(\varepsilon / \mathrm{dm}^{3} \quad \mathrm{~mol}^{-1} \quad \mathrm{~cm}^{-1} 70\right.$ 350); Fluorescence: $\lambda_{\max }(\mathrm{PBS}) / \mathrm{nm} 544$ ( $\left.\Phi_{\mathrm{F}} 7 \%\right)$.

\section{Acknowledgements}

Financial support from Institut Universitaire de France (IUF) and the Burgundy region ("FABER" programme, PARI Action 6, SSTIC 6 "Imagerie, instrumentation, chimie et applications biomédicales"), especially for the Ph. D. grant of S. D., are greatly acknowledged. The authors thank the "Plateforme d'Analyse Chimique et de Synthèse Moléculaire de l'Université de Bourgogne" (PACSMUB, http://www.wpcm.fr) for access to spectroscopy instrumentation. COBRA lab (UMR CNRS 6014) and Iris Biotech company are warmly thanked for the generous gift of some chemical reagents used in this work. The authors also thank Dr. Jean-Alexandre Richard (ICES, A*STAR, Singapore) for relevant comments on this manuscript before publication, Dr. David Monchaud (GATTACA research group, ICMUB, UMR CNRS 6302) for access to UV-vis and fluorescence spectro(photo)meters, Dr. Jérôme Bayardon, Marie-José Penouilh and Marcel Soustelle (University of Burgundy, ICMUB, UMR CNRS 6302) for optical rotation measurements, HRMS measurements and elemental analysis respectively. 


\section{Notes and references}

1. (a) M. Eun Jun, B. Roy and K. Han Ahn, Chem. Commun., 2011, 47, 7583-7601; (b) W. Shi and H. Ma, Chem. Commun., 2011, 48, 8732-8744; (c) J. Chan, S. C. Dodan and C. J. Chang, Nat. Chem., 2012, 4, 973-984; (d) J. B. Grimm, L. M. Heckman and L. D. Lavis, Prog. Mol. Biol. Transl. Sci., 2013, 113, 1-34; (e) Y. Yang, Q. Zhao, W. Feng and F. Li, Chem. Rev., 2013, 113, 192-270; (f) X. Li, X. Gao, W. Shi and H. Ma, Chem. Rev., 2014, 114, 590-659; (g) X. Chen, M. Sun and H. Ma, Curr. Org. Chem., 2006, 10, 477-489.

2. (a) M. Beija, C. A. M. Afonso and J. M. G. Martinho, Chem. Soc. Rev., 2009, 38 2410-2433; (b) H. Zheng, X.-Q. Zhan, Q.-N. Bian and X.-J. Zhang, Chem. Commun. 2013, 49, 429-447; (c) Y. Tang, D. Lee, J. Wang, G. Li, J. Yu, W. Lin and J. Yoon, Chem Soc. Rev., 2015, 44, 5003-5015.

3. For selected examples, see: (a) Y. Huang and J. M. Coull, J. Am. Chem. Soc., 2008 130, 3238-3239; (b) E. V. Anslyn, J. Am. Chem. Soc., 2010, 132, 15833-15835; (c) K. Meguellati, G. Koripelly and S. Ladame, Angew. Chem., Int. Ed., 2010, 49, 2738-2742. 4. (a) Q. Wu and E. V. Anslyn, J. Mater. Chem., 2005, 15, 2815-2819; (b) W. Jian and W. Wang, Chem. Commun., 2009, 3913-3915; (c) J. H. Do, H. N. Kim, J. Yoon, J. S. Kim and H.-J. Kim, Org. Lett., 2010, 12, 932-934; (d) T.-I. Kim, M. S. Jeong, S. J. Chung and Y. Kim, Chem. - Eur. J., 2010, 16, 5297-5300; (e) T.-I. Kim, H. Kim, Y. Cho and Y. Kim, Chem. Commun., 2011, 47, 9825-9827; (f) H. Mohapatra and S. T. Phillips, Angew. Chem. Int. Ed., 2012, 51, 11145-11148; (g) D. Kim, S. Sambasivan, H. Nam, K. Hean Kim, J. Yong Kim, T. Joo, K.-H. Lee, K.-T. Kim and K. Han Ahn, Chem. Commun 2012, 48, 6833-6835; (h) I. Kim, D. Kim, S. Sambasivan and K. H. Ahn, Asian J. Org. Chem., 2012, 1, 60-64; (i) J. Park and Y. Kim, Bioorg. Med. Chem. Lett., 2013, 23, 2332-2335; (j) P. Hou, S. Chen, H. Wang, J. Wang, K. Voitchovsky and X. Song, Chem Commun., 2014, 50, 320-322; (k) J. Kim, J. Park, H. Lee, Y. Choi and Y. Kim, Chem. Commun., 2014, 50, 9353-9356; (I) J. Zhou, Y. Li, J. Shen, Q. Li, R. Wang, Y. Xu and X. Qian, RSC Adv., 2014, 4, 51589-51592; (m) A. D. Brooks, H. Mohapatra and S. T. Phillips, J. Org. Chem., 2015, 80, 10437-10445; (n) H. Mohapatra, H. Kim and S. T. Phillips, J. Am. Chem. Soc., 2015, 137, 12498-12501; (o) Y. Han, C. Yang, K. Wu, Y. Chen, B. Zhou and M. Xia, RSC Adv., 2015, 5, 16723-16726; (p) P. K. Mishra, T. Saha and P. Talukdar, Org. Biomol. Chem., 2015, 13, 7430-7436; (q) H. Zhang, Y. Xie, P. Wang, G. Chen, R. Liu, Y.-W. Lam, Y. Hu, Q. Zhu and H. Sun, Talanta, 2015, 135, 149 154; (r) J. Zhang, Y. Li and W. Guo, Anal. Methods, 2015, 7, 4885-4888; (s) Y. Chen B. Chen, D. Luo, Y. Cai, Y. Wei and Y. Han, Tetrahedron Lett., 2016, 57, 1192-1195; (t) Y. Chen, M. Zhang, Y. Han and J. Wei, RSC Adv, 2016, 6, 8380-8383; (u) Z. Hu, J. Hu, H. Wang, Q. Zhang, M. Zhao, C. Brommesson, Y. Tian, H. Gao, X. Zhang and K. Uvdal, Anal. Chim. Acta, 2016, 933, 189-195; (v) X. Liu, D. Yang, W. Chen, L. Yang, F. Qi and X. Song, Sens. Actuators B-Chem., 2016, 234, 27-33; (w) F. Qi, X. Liu, L. Yang, L. Yang, W. Chen and X. Song, Tetrahedron, 2016, 72, 6909-6913; (x) J. Zhang, Y. Li, J. Zhao and W. Guo, Sens. Actuators B-Chem., 2016, 237, 67-74.

5. (a) T. Tomohiro, K. Kato, S. Masuda, H. Kishi and Y. Hatanaka, Bioconjugate Chem., 2011, 22, 315-318; (b) S. Morimoto, T. Tomohiro, N. Maruyama and $Y$. Hatanaka, Chem. Commun., 2013, 49, 1811-1813; (c) T. Tomohiro, S. Morimoto, T. Shima, J. Chiba and Y. Hatanaka, Angew. Chem., Int. Ed., 2014, 53, 13502-13505; (d) S. Masuda, T. Tomohiro, S. Yamaguchi, S. Morimoto and Y. Hatanaka, Bioorg. Med. Chem. Lett., 2015, 25, 1675-1678; (e) T. Suzuki, T. Okamura, T. Tomohiro, Y. Iwabuch and N. Kanoh, Bioconjugate Chem., 2015, 26, 389-395.

6. S. Debieu and A. Romieu, Org. Biomol. Chem., 2015, 13, 10348-10361.

7. Z. Lei and Y. Yang, J. Am. Chem. Soc., 2014, 136, 6594-6597.

8. L. Song, Z. Lei, B. Zhang, Z. Xu, Z. Li and Y. Yang, Anal. Methods, 2014, 6, $7597-$ 7600.

9. Z. Zhang, B. Zhang, X. Qian, Z. Li, Z. Xu and Y. Yang, Anal. Chem., 2014, 86, 1191911924.

10. (a) Y. Yang, S. K. Seidlits, M. M. Adams, V. M. Lynch, C. E. Schmidt, E. V. Anslyn and J. B. Shear, J. Am. Chem. Soc., 2010, 132, 13114-13116; (b) Q. Zhang, Z. Zhu, Y. Zheng, J. Cheng, N. Zhang, Y.-T. Long, J. Zheng, X. Qian and Y. Yang, J. Am. Chem. Soc 2012, 134, 18479-18482; (c) Q. Zhang, N. Zhang, Y.-T. Long, X. Qian and Y. Yang, Bioconjugate Chem., 2016, 27, 341-353.

11. For selected reviews, see: (a) M. Chhatwal, A. Kumar, V. Singh, R. D. Gupta and S. K. Awasthi, Coord. Chem. Rev., 2015, 292, 30-55; (b) L. Yu, S. Wang, K. Huang, Z. Liu, F. Gao and W. Zeng, Tetrahedron, 2015, 71, 4679-4706; (c) L. He, B. Dong, Y. Liu and W. Lin, Chem. Soc. Rev., 2016, 45, 6449-6461.

12. A. Romieu, Org. Biomol. Chem., 2015, 13, 1294-1306.

13. J. B. Grimm, T. D. Gruber, G. Ortiz, T. A. Brown and L. D. Lavis, Bioconjugate Chem., 2016, 27, 474-480.

14. Y. Yang, Y. Chen, H. Aloysius, D. Inoyama and L. Hu, in Enzyme Technologies: Pluripotent Players in Discovering Therapeutic Agents, eds. H.-C. Yang, W.-K. Yeh and J. R. McCarthy, John Wiley \& Sons, Hoboken, New Jersey, 2014, ch. 5, pp. 213-215. 15. (a) S. Gnaim and D. Shabat, Acc. Chem. Res., 2014, 47, 2970-2984; (b) A. Alouane, R. Labruère, T. Le Saux, F. Schmidt and L. Jullien, Angew. Chem., Int. Ed., 2015, 54, 7492-7509; (c) M. E. Roth, O. Green, S. Gnaim and D. Shabat, Chem. Rev. 2016, 116, 1309-1352.

16. M. Matsui, H. Fowler Jonathan and L. Walling Linda, Biol. Chem., 2006, 387 1535-1544.

17. (a) S. Mizutani, K. Shibata, F. Kikkawa, A. Hattori, M. Tsujimoto, M. Ishii and H. Kobayashi, Expert Opin. Ther. Targets, 2007, 11, 453-461; (b) Q. Gong, W. Shi, L. Li and H. Ma, Chem. Sci., 2016, 7, 788-792; (c) S. Rout and R. K. Mahapatra, Biomed. Pharmacother., 2016, 82, 192-201.

18. C. Tian, Z. Huang and Z. Wen, Inr. J. Gynaecol. Obstet., 2016, 135, 255-258.

19. For selected examples, see: (a) X.-b. Zhang, M. Waibel and J. Hasserodt, Chem. - Eur. J., 2010, 16, 792-795; (b) O. Thorn-Seshold, M. Vargas-Sanchez, S. McKeon and J. Hasserodt, Chem. Commun., 2012, 48, 6253-6255; (c) M. Prost and J. Hasserodt, Chem. Commun., 2014, 50, 14896-14899; (d) M. Prost, L. Canaple, J. Samarut and J. Hasserodt, ChemBioChem, 2014, 15, 1413-1417.

20. G. T. Hermanson, in Bioconjugate Techniques, Academic Press, 3rd edn., 2013, pp. 127-228.

21. D. Maiti and S. L. Buchwald, J. Am. Chem. Soc., 2009, 131, 17423-17429.

22. L. He, X. Yang, Y. Liu and L. Weiying, Anal. Methods, 2016, 8, 8022-8027.

23. A. M. Brouwer, Pure Appl. Chem., 2011, 83, 2213-2228.

24. For selcted examples, see: (a) C. Wei, R. Wang, C. Zhang, G. Xu, Y. Li, Q.-Z. Zhang, L.-Y. Li, L. Yi and Z. Xi, Chem. - Asian. J., 2016, 11, 1376-1381; (b) C. Zhang, L. Wei, C. Wei, J. Zhang, R. Wang, Z. Xi and L. Yi, Chem. Commun., 2015, 51, 7505-7508; (c) H. Zhang, C. Zhang, R. Liu, L. Yi and H. Sun, Chem. Commun., 2015, 51, 2029-2032.

25. E. L. Smith and D. H. Spackman, J. Biol. Chem., 1955, 212, 271-299.

26. A. Erarslan and A. Güray, J. Chem. Technol. Biotechnol., 1991, 51, 181-195.

27. K. V. Lavrov, I. A. Zalunin, E. K. Kotlova and A. S. Yanenko, Biochemistry (Moscow), 2010, 75, 1006-1013.

28. J. B. Grimm and L. D. Lavis, Org. Lett., 2011, 13, 6354-6357.

29. M. El Baraka, M. Deumié, P. Viallet and T. J. Lampidis, J. Photochem. Photobiol. A-Chem., 1991, 56, 295-311.

30. For selected reviews, see: (a) C.-H. Tung, Biopolymers, 2004, 76, 391-403; (b) C. R. Drake, D. C. Miller and E. F. Jones, Curr. Org. Synth., 2011, 8, 498-520; (c) L. Chen, J. Li, L. Du and M. Li, Med. Res. Rev., 2014, 34, 1217-1241; (d) H.-Y. Hu, S. Gehrig, G. Reither, D. Subramanian, M. A. Mall, O. Plettenburg and C. Schultz, Biotechnol. J., 2014, 9, 266-281; (e) M. Garland, Joshua J. Yim and M. Bogyo, Cell Chem. Biol., 2016, 23, $122-136$.

31. (a) K. Kolmakov, V. N. Belov, C. A. Wurm, B. Harke, M. Leutenegger, C. Eggeling and S. W. Hell, Eur. J. Org. Chem., 2010, 3593-3610; (b) J. B. Grimm, A. J. Sung, W. R. Legant, P. Hulamm, S. M. Matlosz, E. Betzig and L. D. Lavis, ACS Chem. Biol., 2013, 8 1303-1310.

32. For a review, see: Y. Kushida, T. Nagano and K. Hanaoka, Analyst, 2015, 140, 685-695.

33. (a) T. Pastierik, P. Šebej, J. Medalová, P. Štacko and P. Klán, J. Org. Chem., 2014, 79, 3374-3382; (b) P. Horváth, P. Šebej, T. Šolomek and P. Klán, J. Org. Chem., 2015, 80, 1299-1311.

34. (a) X. Chai, X. Cui, B. Wang, F. Yang, Y Cai, Q. Wu and T. Wang, Chem. - Eur. J. 2015, 21, 16754-16758; (b) X. Zhou, R. Lai, J. R. Beck, H. Li and C. I. Stains, Chem. Commun., 2016, 52, 12290-12293.

35. J. Liu, Y.-Q. Sun, H. Zhang, H. Shi, Y. Shi and W. Guo, ACS Appl. Mater. Interfaces, 2016, 8, 22953-22962.

36. For recent examples, see: (a) W. Pan, H. Yang, N. Li, L. Yang and B. Tang, Chem. - Eur. J., 2015, 21, 6070-6073; (b) I. Takashima, R. Kawagoe, I. Hamachi and A. Ojida, Chem. - Eur. J., 2015, 21, 2038-2044; (c) S.-Y. Li, L.-H. Liu, H. Cheng, B. Li, W.-X. Qiu and X.-Z. Zhang, Chem. Commun., 2015, 51, 14520-14523; (d) Wen, Y.; Xue, F.; Lan, H.; Li, Z.; Xiao, S.; Yi, T., Biosens. Bioelectron. 2017, 91, 115-121.

37. G. R. Fulmer, A. J. M. Miller, N. H. Sherden, H. E. Gottlieb, A. Nudelman, B. M. Stoltz, J. E. Bercaw and K. I. Goldberg, Organometallics, 2010, 29, 2176-2179. 
<smiles>CCN(CC)c1cccc(Oc2cc(N(CC)CC)ccc2C=O)c1</smiles>

0

NA570

Lei and Yang 2014

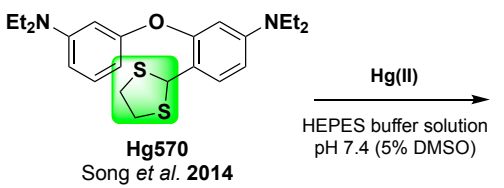

Song et al. 2014

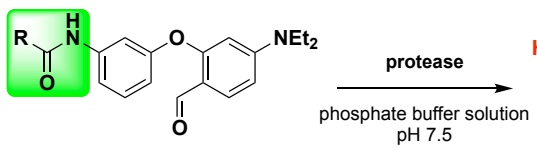

This work

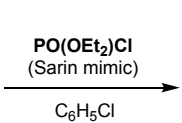

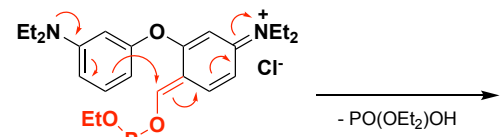

EtO'

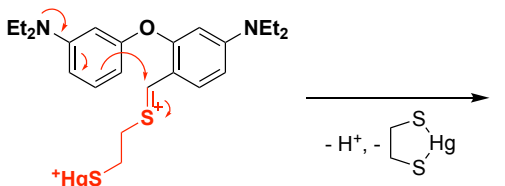

${ }^{\mathrm{H}_{2} \mathrm{~N}}$

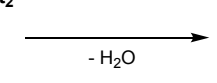

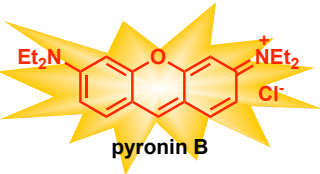
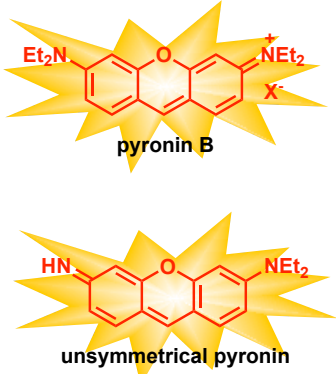

Fig. 1 Background information about the "covalent-assembly" principle applied to in vitro fluorogenic detection of organophosphorus nerve agents (Sarin mimics) and $\mathrm{Hg}(\mathrm{II})$ cation through in situ synthesis of pyronin $\mathrm{B}$ ( $\mathrm{X}^{-}=$anionic form of HEPES), and its extension to protease sensing explored in this work (unsymmetrical pyronin = 6-N,N-diethylamino-3H-xanthen-3-imine = compound 6 ).

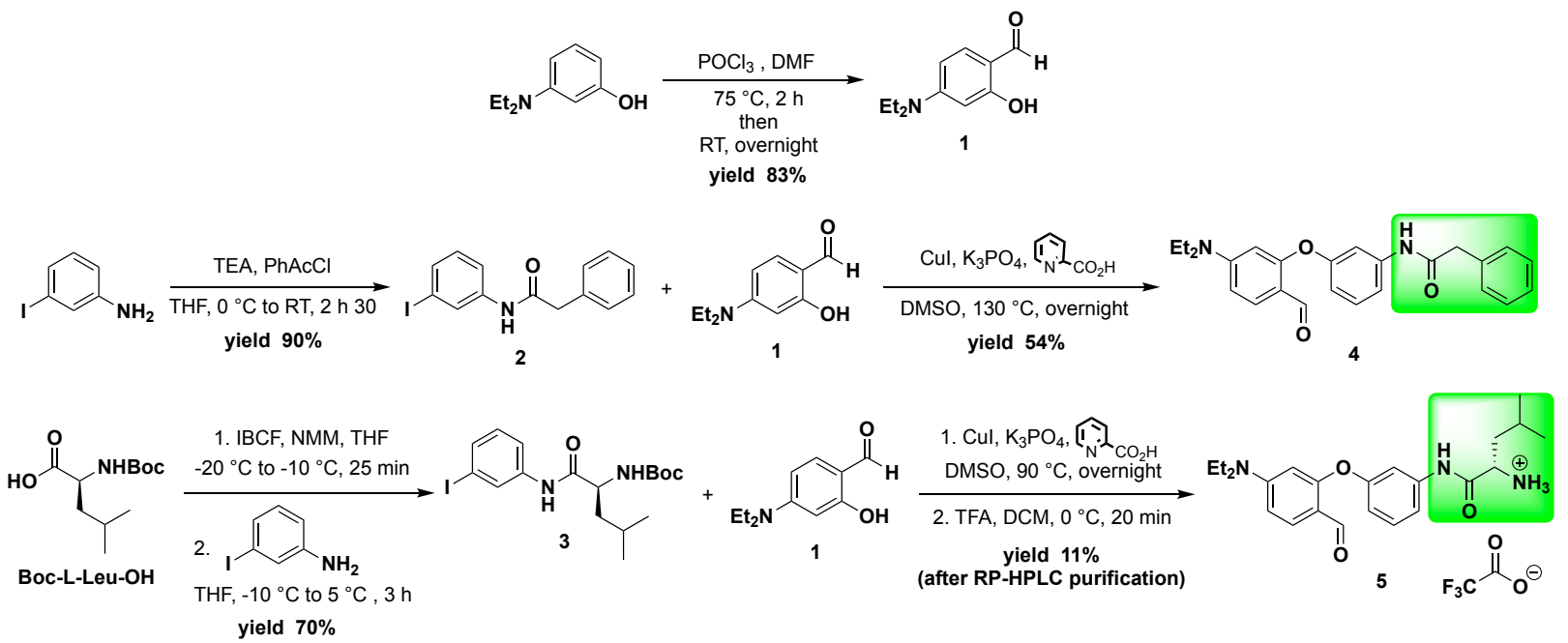

Scheme 1 Synthesis of protease-sensitive fluorescence "turn-on" probes $\mathbf{4}$ and $\mathbf{5}$ based on the "covalent-assembly" principle (Boc = tert-butyloxycarbonyl, IBCF $=$ isobutyl chloroformate, $\mathrm{NMM}=\mathrm{N}$-methylmorpholine, $\mathrm{PhACl}=$ phenylacetyl chloride). 

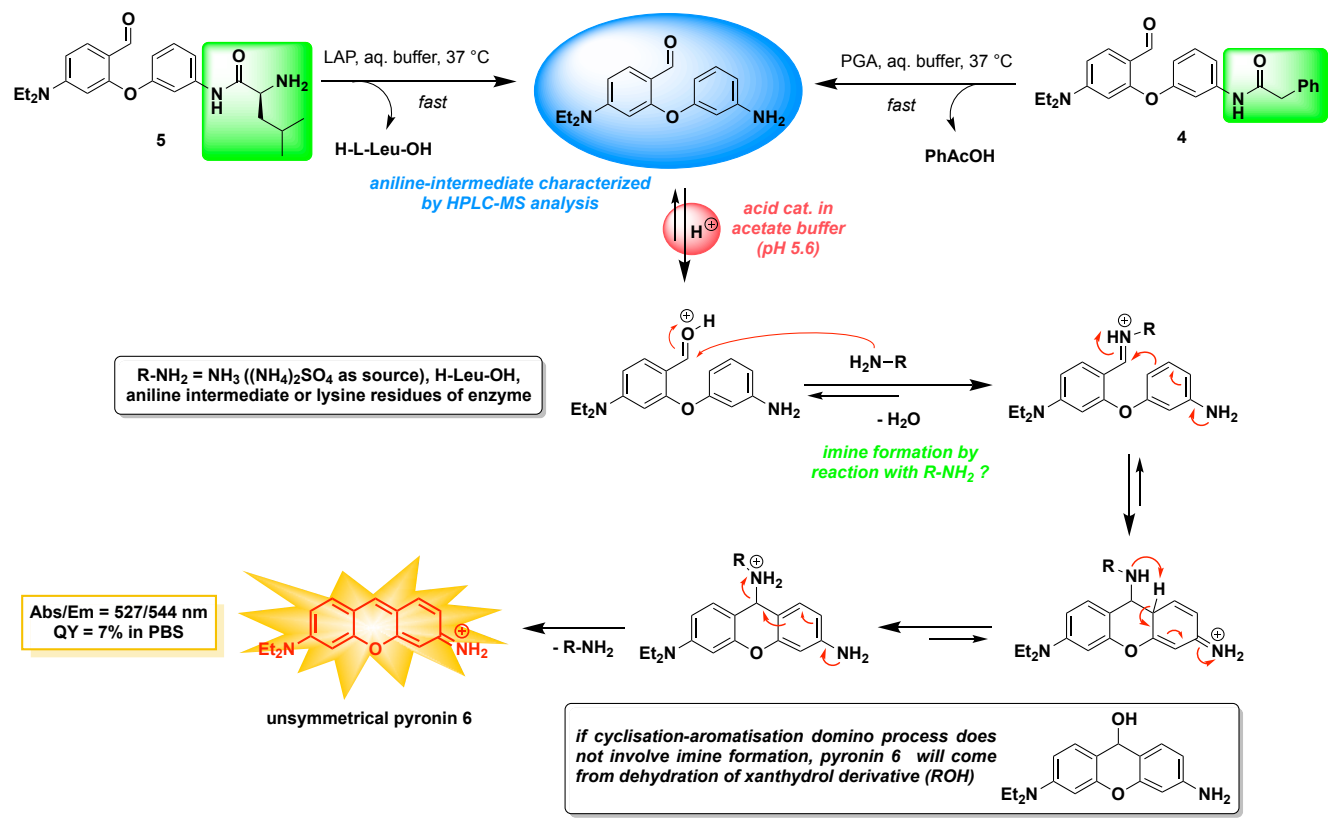

Fig. 4 Proposed detection mechanism of proteases via the "covalent-assembly" principle, supported by fluorescence-based in vitro assays and HPLCfluorescence/-MS analyses performed with PGA-sensitive probe $\mathbf{4}$ and LAP-sensitive probe $\mathbf{5}$. 


\section{In situ formation of pyronin dyes for fluorescence protease sensing}

Sylvain Debieu ${ }^{\mathrm{a}}$ and Anthony Romieu ${ }^{* a, \mathrm{~b}}$

${ }^{a}$ Institut de Chimie Moléculaire de l'Université de Bourgogne, UMR 6302, CNRS, Univ.

Bourgogne Franche-Comté, 9 Avenue Alain Savary, 21078 Dijon, France

Fax: $+33(0) 380396117$

Tel: $+33(0) 380393624$

E-mail: anthony.romieu@u-bourgogne.fr

Lab homepage: http://www.icmub.fr

${ }^{b}$ Institut Universitaire de France, 103 Boulevard Saint-Michel, 75005 Paris, France

\section{Supporting Information}




\section{Table of Contents}

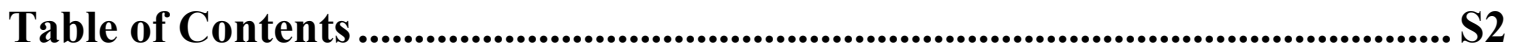

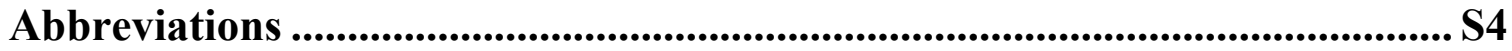

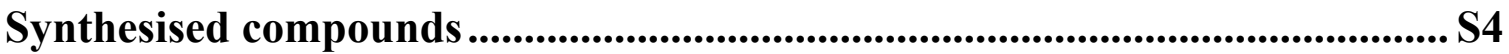

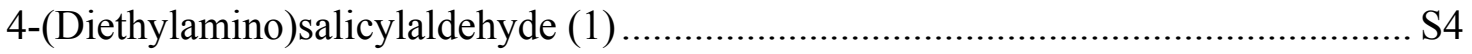

In vitro activation of fluorogenic "turn-on" probes 4 and 5 by PGA and LAP experimental details .................................................................................................. S6

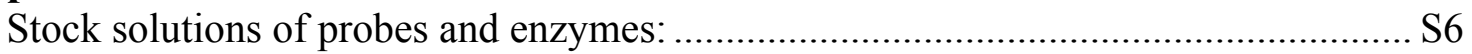

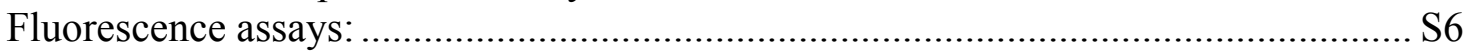

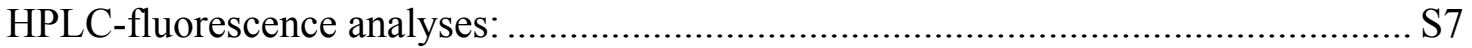

HPLC-MS analyses (enzyme assay and sample treatment):....................................... S7

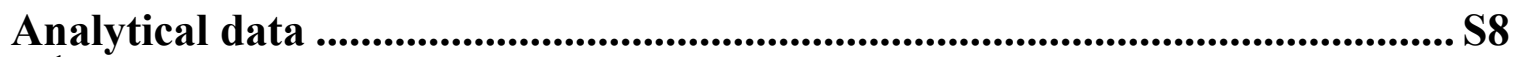

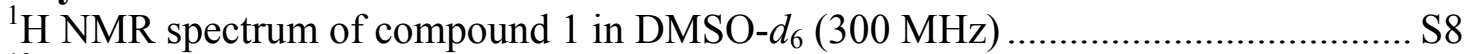

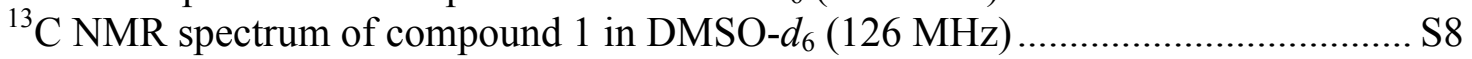

ESI+ / ESI- mass spectra (low resolution) and UV-vis spectrum of compound 1 ....... S9

RP-HPLC elution profile of compound 1 (system A, detection at $260 \mathrm{~nm}$ )............... S9

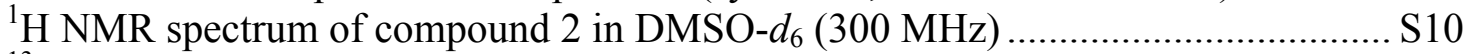

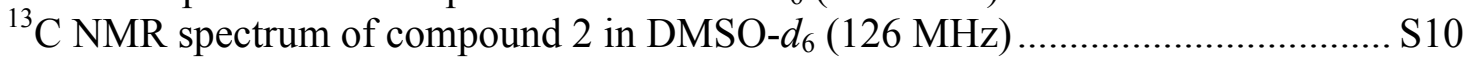

ESI+ / ESI- mass spectra (low resolution) and UV-vis spectrum of compound 2 ..... S11

RP-HPLC elution profile of compound 2 (system A, detection at $260 \mathrm{~nm}$ ).............. S11

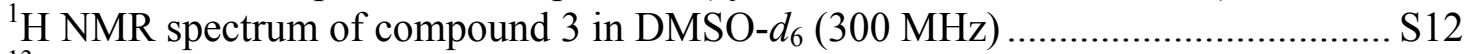

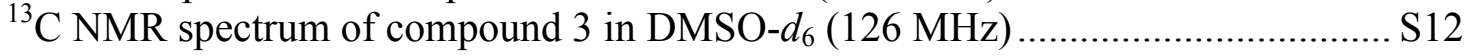

ESI+ / ESI- mass spectra (low resolution) and UV-vis spectrum of compound 3 ..... S13

RP-HPLC elution profile of compound 3 (system A, detection at $260 \mathrm{~nm}$ ).............. S13

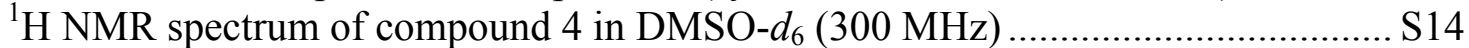

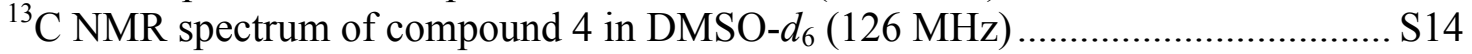

ESI+ / ESI- mass spectra (low resolution) and UV-vis spectrum of compound 4 ..... S15

RP-HPLC elution profile of compound 4 (system A, detection at $260 \mathrm{~nm}$ ).............. S15

ESI+ mass spectrum (high resolution) of compound 4 …….................................. S16

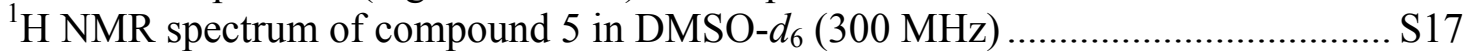

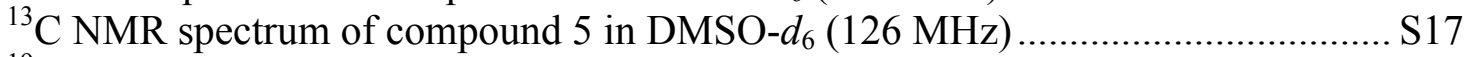

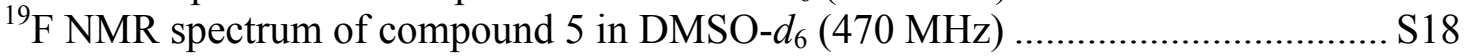

ESI+ / ESI- mass spectra (low resolution) and UV-vis spectrum of compound 5 .... S18

RP-HPLC elution profile of compound 5 (system A, detection at $260 \mathrm{~nm}$ ).............. S19

ESI+ mass spectrum (high resolution) of compound 5 ……................................... S19

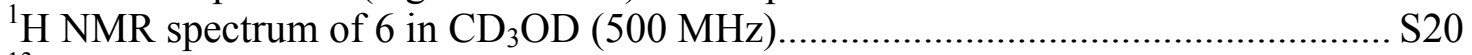

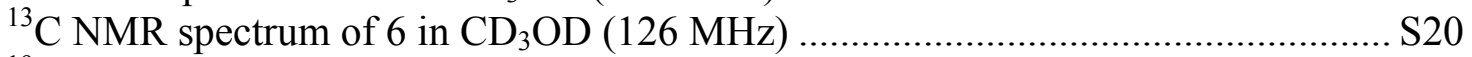

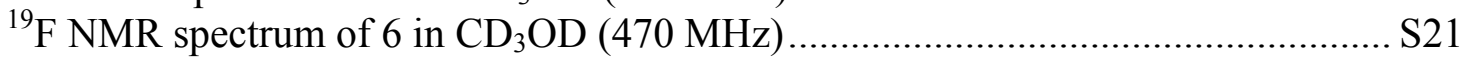

ESI+ / ESI- mass spectrum (low resolution) and UV-vis spectrum of compound 6.. S21

RP-HPLC elution profile of compound 6 (system B, detection at $260 \mathrm{~nm}$ ) .............. S22

RP-HPLC elution profile of compound 6 (system B, detection at $500 \mathrm{~nm}$ ) .............. S22

Fig. S1 Normalised UV-vis absorption spectra of fluorogenic probes 4 and 5 in PB (+ $0.3 \% \mathrm{CH}_{3} \mathrm{CN}$ and $0.15 \% \mathrm{CH}_{3} \mathrm{CN}$ respectively) at $25^{\circ} \mathrm{C}$. $\mathrm{S} 23$ 
Fig. S2 Normalised absorption, excitation (Em. $545 \mathrm{~nm}$ ) and emission (Ex. $460 \mathrm{~nm}$ ) spectra of the pyronin 6 in $\mathrm{PB}$ at $25^{\circ} \mathrm{C}$.

Fig. S3 Overlayed fluorescence emission spectra (Ex. $460 \mathrm{~nm})$ of PGA-fluorogenic probe 4, LAP-fluorogenic probe 5 and pyronin 6 in $\mathrm{PB}$ at $25^{\circ} \mathrm{C}$ (concentration: $1 \mu \mathrm{M}$ )

Fig. S4 Time-dependant changes in the green-yellow fluorescence intensity (Ex. 525 $\mathrm{nm} /$ Em. $545 \mathrm{~nm}$, bandwidth $5 \mathrm{~nm}$ ) of fluorogenic probe 4 (concentration: $1 \mu \mathrm{M}$ ) in the

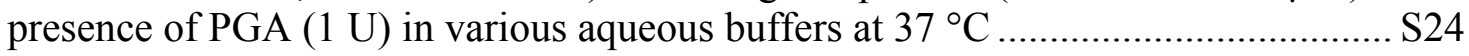
Fig. S5 Time-dependant changes in the green-yellow fluorescence intensity (Ex. $525 \mathrm{~nm}$ / Em. $545 \mathrm{~nm}$, bandwidth $5 \mathrm{~nm}$ ) of fluorogenic probe 4 in aqueous buffers at $37{ }^{\circ} \mathrm{C}$ (blanks) $\mathrm{S} 25$

Fig. S6 Time-dependant changes in the green-yellow fluorescence intensity (Ex. $525 \mathrm{~nm}$ / Em. $545 \mathrm{~nm}$, bandwidth $5 \mathrm{~nm})$ of fluorogenic probe 5 in the presence of LAP $\left(2 \times 10^{-3}\right.$ $\mathrm{U})$ in various aqueous buffers at $37^{\circ} \mathrm{C}$..... $\mathrm{S} 25$

Fig. S7 Time-dependant changes in the green-yellow fluorescence intensity (Ex. $525 \mathrm{~nm}$ / Em. $545 \mathrm{~nm}$, bandwidth $5 \mathrm{~nm}$ ) of fluorogenic probe 5 in aqueous buffers at $37{ }^{\circ} \mathrm{C}$ (blanks) S26

Fig. S8 Overlayed fluorescence emission spectra (Ex. $460 \mathrm{~nm}$, bandwidth $5 \mathrm{~nm}$ ) of enzymatic reaction mixtures (probe 5) after $24 \mathrm{~h}$ of incubation at $37^{\circ} \mathrm{C}$ and authentic sample of pyronin 6 at the same concentration S26 Fig. S9 Overlayed fluorescence emission spectra (Ex. $460 \mathrm{~nm}$, bandwidth $5 \mathrm{~nm}$ ) of enzymatic reaction mixtures (probe 4 ) after $24 \mathrm{~h}$ of incubation at $37^{\circ} \mathrm{C}$ S27

Fig. S10 RP-HPLC elution profiles (fluorescence detection, system $\mathrm{H}$ ) of fluorogenic probes 4 and 5 before enzymatic activation S27

Fig. S11 RP-HPLC elution profiles (fluorescence detection, system $\mathrm{H}$ ) of fluorogenic probes 4 and 5 without enzymatic activation ( $24 \mathrm{~h}$ of incubation)... S28

Fig. S12 RP-HPLC elution profiles (fluorescence detection, system $\mathrm{H}$ ) of fluorogenic probes 4 and 5 after enzymatic activation $(24 \mathrm{~h})$ and reference 6 S29 Fig. S13 Time-dependant changes in the green-yellow fluorescence intensity (Ex. 525 $\mathrm{nm} /$ Em. $545 \mathrm{~nm}$, bandwidth $5 \mathrm{~nm}$ ) of fluorogenic probe 4 (concentration: $1 \mu \mathrm{M}$ ) in the presence of LAP $\left(2 \times 10^{-3} \mathrm{U}\right)$ in $\mathrm{PB}$ at $37^{\circ} \mathrm{C}$ (negative control) .... S31 Fig. S14 Time-dependant changes in the green-yellow fluorescence intensity (Ex. 525 $\mathrm{nm} / \mathrm{Em} .545 \mathrm{~nm}$, bandwidth $5 \mathrm{~nm}$ ) of fluorogenic probe 5 (concentration: $1 \mu \mathrm{M}$ ) in the presence of PGA (1 U) in $\mathrm{PB}$ at $37^{\circ} \mathrm{C}$ (negative control) S31

Fig. S15 RP-HPLC-MS analyses - Identification of "relevant" molecules/ intermediates formed during the enzymatic activation of probes 4 and 5 (system $\mathrm{G}$ ). S32 Fig. S16 RP-HPLC elution profiles (system G) of fluorogenic probe 4 after incubation in PB alone ( 0 min and after $24 \mathrm{~h}$ ) or with enzyme (PGA: $2 \mathrm{~h}, 5 \mathrm{~h}, 8 \mathrm{~h}$ and $24 \mathrm{~h}$ ) .... S33 Fig. S17 RP-HPLC elution profiles (system G) of fluorogenic probe 5 after incubation in PB alone ( 0 min and after $24 \mathrm{~h}$ ) or with enzyme (LAP: $2 \mathrm{~h}, 5 \mathrm{~h}, 8 \mathrm{~h}$ and $24 \mathrm{~h}$ ).... S36 


\section{Abbreviations}

The following abbreviations are used throughout the text of the ESI file: Abs, absorption; ATR, attenuated total reflectance; $\mathrm{CH}_{3} \mathrm{CN}$, acetonitrile; $\mathrm{CH}_{3} \mathrm{OH}$, methanol; DCM, dichloromethane; DMF, $N, N$-dimethylformamide; DMSO, dimethylsulfoxide; equiv., equivalent(s); Em, emission; EtOAc, ethyl acetate; EtOH, ethanol; ESI, electrospray ionisation; Ex, excitation; FA, formic acid; HPLC, high-pressure liquid chromatography; IR, infrared; LAP, leucyl-aminopeptidase; LRMS, low-resolution mass spectrum; min, minutes; $\mathrm{NaHCO}_{3}$, sodium hydrogenocarbonate; $\mathrm{NaOAc}$, sodium acetate; $\left(\mathrm{NH}_{4}\right)_{2} \mathrm{SO}_{4}$, ammonium sulfate; NMR, nuclear magnetic resonance; $\mathrm{PB}$, phosphate buffer; PBS, phosphate buffered saline; PGA, penicillin G acylase; $\mathrm{MgCl}_{2}$, magnesium chloride; MS, mass spectrometry; RP, reversed phase; rpm, revolution per minute; RT, room temperature; $t_{\mathrm{R}}$, retention time; UV, ultraviolet; vis, visible.

\section{Synthesised compounds}

\section{4-(Diethylamino)salicylaldehyde (1)}

(CAS number :17754-90-4)

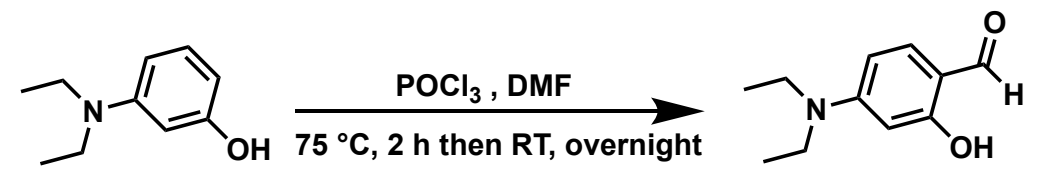

Phosphorous oxychloride $\left(\mathrm{POCl}_{3}\right)(7.0 \mathrm{~mL}, 72.6 \mathrm{mmol}, 3$ equiv.) was added dropwise to dry DMF ( $9.5 \mathrm{ml}, 121 \mathrm{mmol}, 5$ equiv.) at $0{ }^{\circ} \mathrm{C}$. Then $3-(N, N$-diethylamino)phenol $(4.0 \mathrm{~g}$, $24.2 \mathrm{mmol}, 1$ equiv.) in dry DMF $(15 \mathrm{~mL})$ was slowly added to the previous mixture and the resulting solution was heated at $75^{\circ} \mathrm{C}$ for $2 \mathrm{~h} 30$ and at RT overnight. Thereafter, the reaction mixture was cooled to $\mathrm{RT}$, poured into ice cold water and neutralized with aq. saturated $\mathrm{NaHCO}_{3}$ and then the solid was collected by filtration. The solid was retaken with DCM and filtrated over a plug of silica gel, eluted with DCM/EtOAc $(9: 1, \mathrm{v} / \mathrm{v})$. The filtrate was evaporated under vaccum and the product 1 was cristalised in EtOH/ water $(9$ $: 1, \mathrm{v} / \mathrm{v}$ ) to afford $\mathbf{1}$ as white solid (3.9 g, yield 83\%). IR (ATR): $v=3374$ (broad), 2974, 1624, 1558, 1517, 1490, 1446, 1414, 1378, 1335, 1303, 1236, 1217, 1186, 1125, 1096, $1077,1012,958,869,841,802,772,721 \mathrm{~cm}^{-1} ;{ }^{1} \mathrm{H}$ NMR (300 MHz, DMSO- $\left.d_{6}\right): \delta=1.12$ (t, $J=7.2 \mathrm{~Hz}, 6 \mathrm{H}, \mathrm{C} \underline{H}_{3}-\mathrm{Et}$ ), 3.39 (q, $J=7.0 \mathrm{~Hz}, 4 \mathrm{H}, \mathrm{C}_{2}-\mathrm{Et}$ ), 6.04 (d, $J=2.4 \mathrm{~Hz}, 1 \mathrm{H}, \underline{H}-$ Ar), 6.34 (dd, $J=2.4 \mathrm{~Hz}, J=9.0 \mathrm{~Hz}, 1 \mathrm{H}, \underline{H}-\mathrm{Ar}), 7.42$ (d, $J=9.0 \mathrm{~Hz}, 1 \mathrm{H}, \underline{H}-\mathrm{Ar}), 9.61$ (s, $1 \mathrm{H}, \underline{H}$-formyl), 11.26 (s, $1 \mathrm{H}, \mathrm{O} \underline{H}) \mathrm{ppm} ;{ }^{13} \mathrm{C}$ NMR $\left(126 \mathrm{MHz}, \mathrm{DMSO}-d_{6}\right): \delta=12.4(2 \mathrm{C}$, $\mathrm{CH}_{3}$-Et), 44.1 (2 C, $\left.\underline{C H}_{2}-\mathrm{Et}\right), 95.9,104.4,111.2,134.0,153.8,163.4,190.6$ ppm; HPLC (system A): $t_{\mathrm{R}}=4.6 \mathrm{~min}$ (purity $100 \%$ at $260 \mathrm{~nm}$ and $360 \mathrm{~nm}$ ); LRMS (ESI+, recorded

\footnotetext{
${ }^{1}$ V. S. Padalkar, A. Tathe, V. D. Gupta, V. S. Patil, K. Phatangare and N. Sekar, J. Fluoresc., 2012, 22, 311 322.
} 
during RP-HPLC analysis): $m / z$ 194.2 $[\mathrm{M}+\mathrm{H}]^{+}(100)$ and $235.2\left[\mathrm{M}+\mathrm{H}+\mathrm{CH}_{3} \mathrm{CN}\right]^{+}$(30), calcd for $\mathrm{C}_{11} \mathrm{H}_{16} \mathrm{NO}_{2}{ }^{+}$194.1; LRMS (ESI-, recorded during RP-HPLC analysis): $m / z$ 192.1 $[\mathrm{M}-\mathrm{H}]^{-}(20)$, calcd for $\mathrm{C}_{11} \mathrm{H}_{14} \mathrm{NO}_{2}^{-} 192.1$. 


\section{In vitro activation of fluorogenic "turn-on" probes 4 and 5 by PGA and LAP - experimental details}

\section{Stock solutions of probes and enzymes:}

- Mixture A: A stock solution (1.0 mg / mL) of PGA fluorogenic probe 4 in HPLC-grade $\mathrm{CH}_{3} \mathrm{CN}$ (final concentration: $2.48 \mathrm{mM}$ ),

- Mixture B: A stock solution (1.0 mg / mL) of LAP fluorogenic probe 5 in $\mathrm{H}_{2} \mathrm{O} / \mathrm{CH}_{3} \mathrm{CN}$ $(1: 1, \mathrm{v} / \mathrm{v})$ (final concentration: $1.47 \mathrm{mM})$,

- Mixture C: Commercial PGA ( $841 \mathrm{U} / \mathrm{mL}$ ) directly used without dilution,

- Mixture D: $14.2 \mu \mathrm{L}$ of the commercial LAP suspension was dissolved in $985.8 \mu \mathrm{L}$ of ultrapure water $(1 \mathrm{U} / \mathrm{mL})$,

- Mixture E: $5.43 \mathrm{mg}$ of ammonium sulfate in $825 \mu \mathrm{L}$ of water $(6.58 \mathrm{mg} / \mathrm{mL}, 50 \mathrm{mM})$

- Mixture F: $25 \mu \mathrm{L}$ of a $\mathrm{MgCl}_{2}$ stock solution (prepared with $0.48 \mathrm{mg}$ of $\mathrm{MgCl}_{2}$ in $505 \mu \mathrm{L}$ of water $(0.95 \mathrm{mg} / \mathrm{mL}))$ diluted in $475 \mu \mathrm{L}$ of water $(0.05 \mathrm{mM})$,

Stock solutions $(1.0 \mathrm{mg} / \mathrm{mL}$ ) of $\mathbf{6}$ were also prepared in DMSO (for spectroscopy, $99.9 \%$, ACROS, 167852500) and subsquently diluted with PBS for UV-vis absorption and fluorescence measurements, and PB for HPLC-fluorescence analyses.

\section{Fluorescence assays:}

All assay were performed at $37{ }^{\circ} \mathrm{C}$ (using a Peltier temperature controler and water circulation, and conducted with magnetic stirring, $\mathrm{rpm}=300$ ). For both probes $\mathbf{4}$ and $\mathbf{5}$, the fluorescence emission of the release 6- $\mathrm{N}, \mathrm{N}$-diethylamino-3H-xanthen-3-imine was monitored at $\lambda=545 \mathrm{~nm}$ (bandwidth $=5 \mathrm{~nm})($ Ex. $\lambda=525 \mathrm{~nm}$, bandwidth $=5 \mathrm{~nm})$ over time with measurements recorded every $5 \mathrm{~s}$.

\section{Protocol:}

Probe 4 - Into a $3.5 \mathrm{~mL}$ fluorescence quartz cell, $1.2 \mu \mathrm{L}$ of mixture A was diluted in $3 \mathrm{~mL}$ of selected aq. buffer (final concentration of probe: $1 \mu \mathrm{M}$ ) with additive (none or $2 \mu \mathrm{L}$ of $\mathrm{E}$ or $6 \mu \mathrm{L}$ of $\mathrm{F}$ or both) and the resulting mixture was incubated for $5 \mathrm{~min}$. Then $1.2 \mu \mathrm{L}$ of enzyme solution (mixture $\mathrm{C}, 1 \mathrm{U}$ ) was added.

Probe 5 - Into a $3.5 \mathrm{~mL}$ fluorescence quartz cell, $2 \mu \mathrm{L}$ of mixture B was diluted in $3 \mathrm{~mL}$ of selected aq. buffer (final concentration of probe: $1 \mu \mathrm{M}$ ) and the resulting mixture was incubated for $5 \mathrm{~min}$. Then, $2 \mu \mathrm{L}$ of enzyme solution (mixture $\mathrm{D}, 0.002 \mathrm{U}$ ) was added.

Protocol for negative controls:

Probe 4 - Into a $3.5 \mathrm{~mL}$ fluorescence quartz cell, $1.2 \mu \mathrm{L}$ of mixture A was diluted in $3 \mathrm{~mL}$ of PB (100 mM, pH 7.6) and the resulting mixture was incubated for $5 \mathrm{~min}$. Then $2 \mu \mathrm{L}$ of LAP solution (mixture D, $0.002 \mathrm{U}$ ) was added. 
Probe 5 - Into a $3.5 \mathrm{~mL}$ fluorescence quartz cell, $2 \mu \mathrm{L}$ of mixture B was diluted in $3 \mathrm{~mL}$ of selected PB (100 mM, pH 7.6) and the resulting mixture was incubated for $5 \mathrm{~min}$. Then, $1.2 \mu \mathrm{L}$ of PGA solution (mixture $\mathrm{C}, 1 \mathrm{U}$ ) was added.

\section{HPLC-fluorescence analyses:}

Enzymatic reaction mixtures from fluorescence assays were directly analysed by RPHPLC-fluorescence after an incubation time of $24 \mathrm{~h}$ (injected volume: $10 \mu \mathrm{L}$, system $\mathrm{H}$ ).

\section{HPLC-MS analyses (enzyme assay and sample treatment):}

\section{Incubation protocols:}

Probe 4 - $39 \mathrm{nmol}$ (16 $\mu \mathrm{L}$ of mixture A) fluorogenic PGA-sensitive probe was dissolved in selected aq. buffer $(470 \mu \mathrm{L})$ containing $1.2 \mu \mathrm{L}$ of PGA solution (mixture $\mathrm{C}, 1 \mathrm{U}$ ) and the resulting enzymatic reaction mixture was incubated at $37^{\circ} \mathrm{C}$ for $24 \mathrm{~h}$.

Probe 5 - $39 \mathrm{nmol}$ ( $27 \mu \mathrm{L}$ of mixture B) fluorogenic LAP-sensitive probe was dissolved in selected aq. buffer $(420 \mu \mathrm{L})$ containing $50 \mu \mathrm{L}$ of LAP solution (mixture D, $0.05 \mathrm{U}$ ) and the resulting enzymatic reaction mixture was incubated at $37^{\circ} \mathrm{C}$ for $24 \mathrm{~h}$. Samples $(50 \mu \mathrm{L})$ were taken at $30 \mathrm{~min}, 2 \mathrm{~h}, 5 \mathrm{~h}, 8 \mathrm{~h}$ and $24 \mathrm{~h}$ of reaction and were treated as described below.

\section{Samples treatment for HPLC-MS analysis:}

Withdrawn sample $(50 \mu \mathrm{L})$ was diluted with $50 \mu \mathrm{L}$ of $\mathrm{CH}_{3} \mathrm{CN}$, then vortexed followed by centrifugation (9 $000 \mathrm{rpm}, 2 \mathrm{~min}$ ) and finally, $75 \mu \mathrm{L}$ of the supernatant was collected and diluted with $25 \mu \mathrm{L}$ of ultrapure $\mathrm{H}_{2} \mathrm{O} .15 \mu \mathrm{L}$ was injected into the HPLC-MS apparatus (system G). 


\section{Analytical data}

\section{${ }^{1} \mathrm{H}$ NMR spectrum of compound 1 in DMSO- $d_{6}(300 \mathrm{MHz})$}

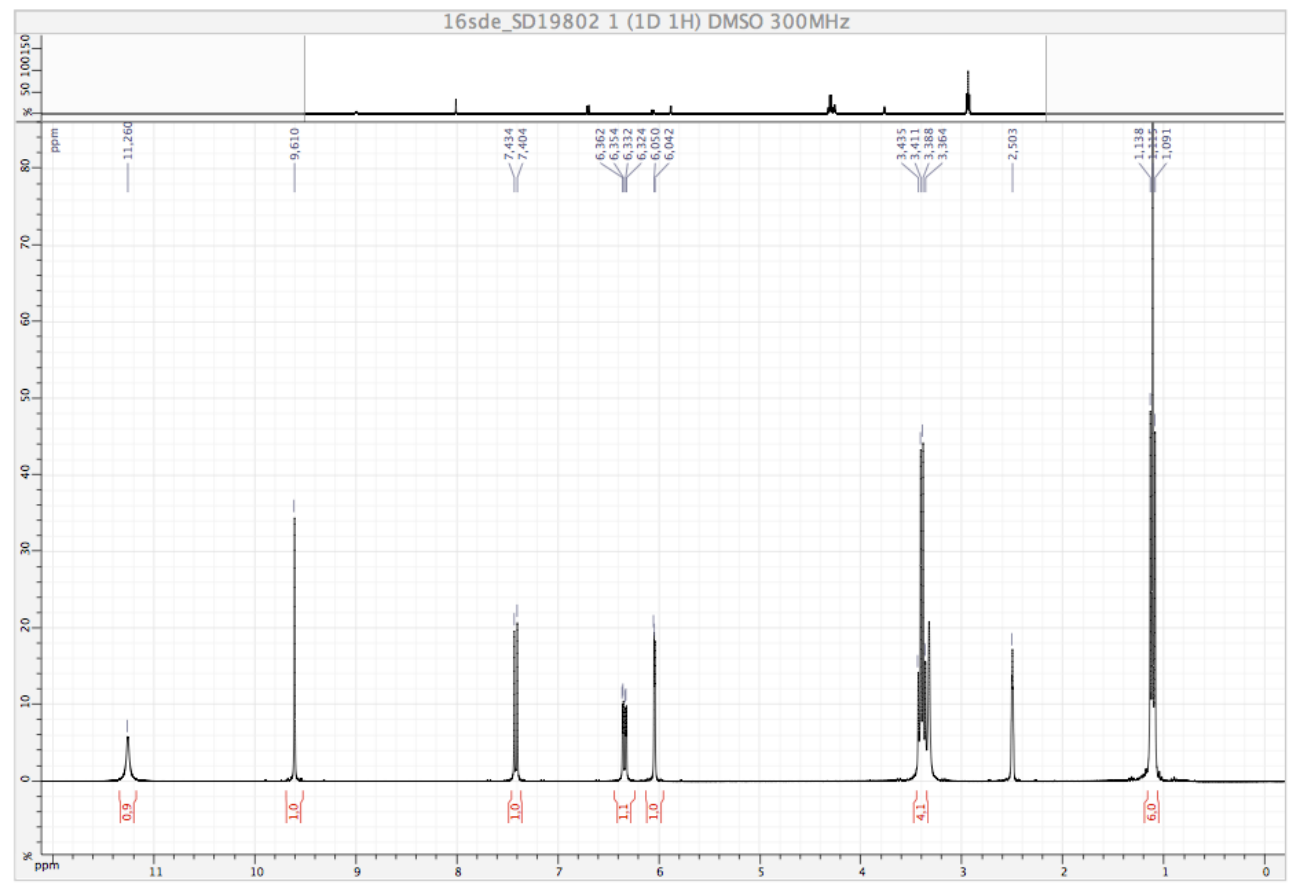

${ }^{13} \mathrm{C}$ NMR spectrum of compound 1 in DMSO- $d_{6}(126 \mathrm{MHz})$

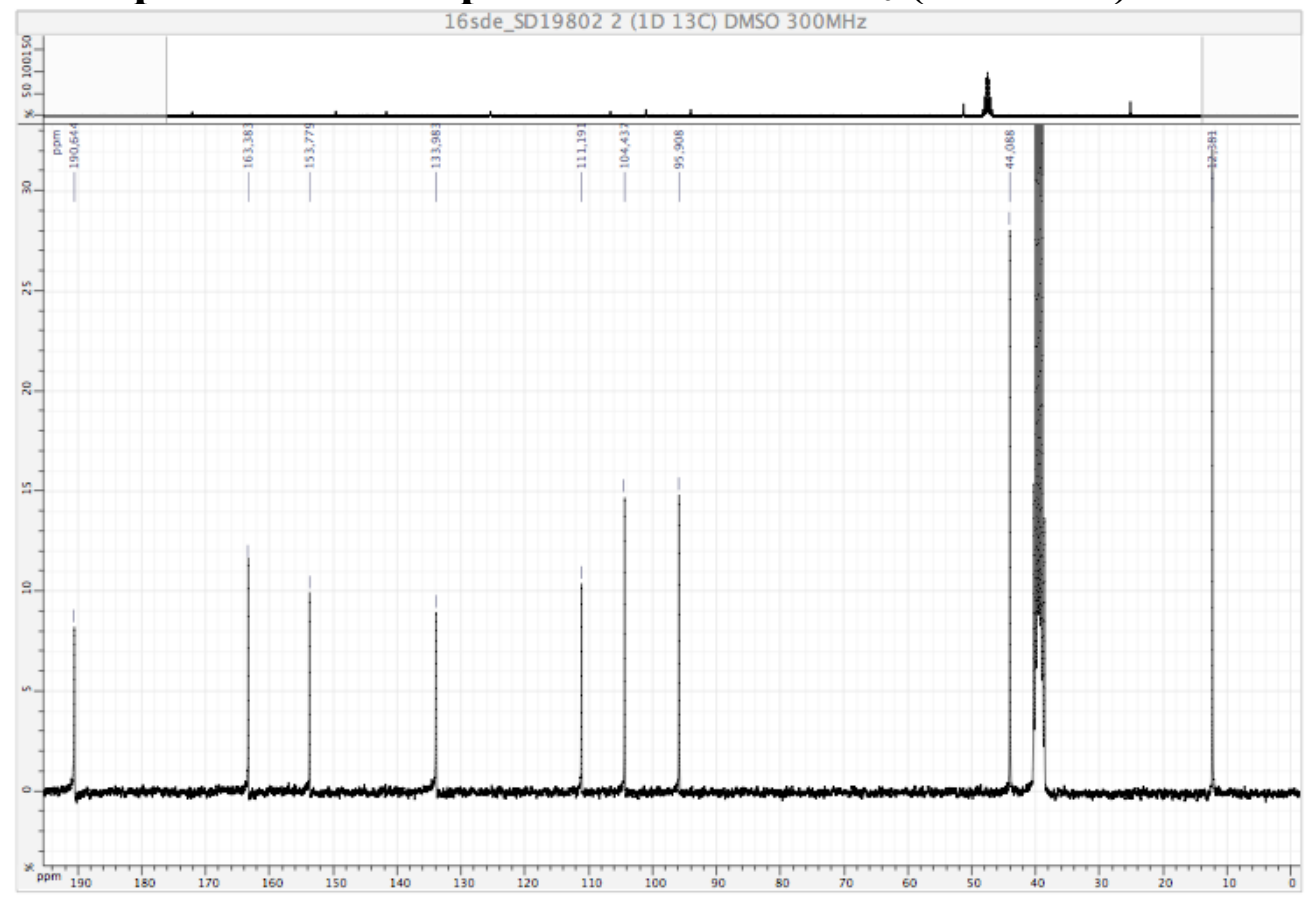


ESI+ / ESI- mass spectra (low resolution) and UV-vis spectrum of compound 1

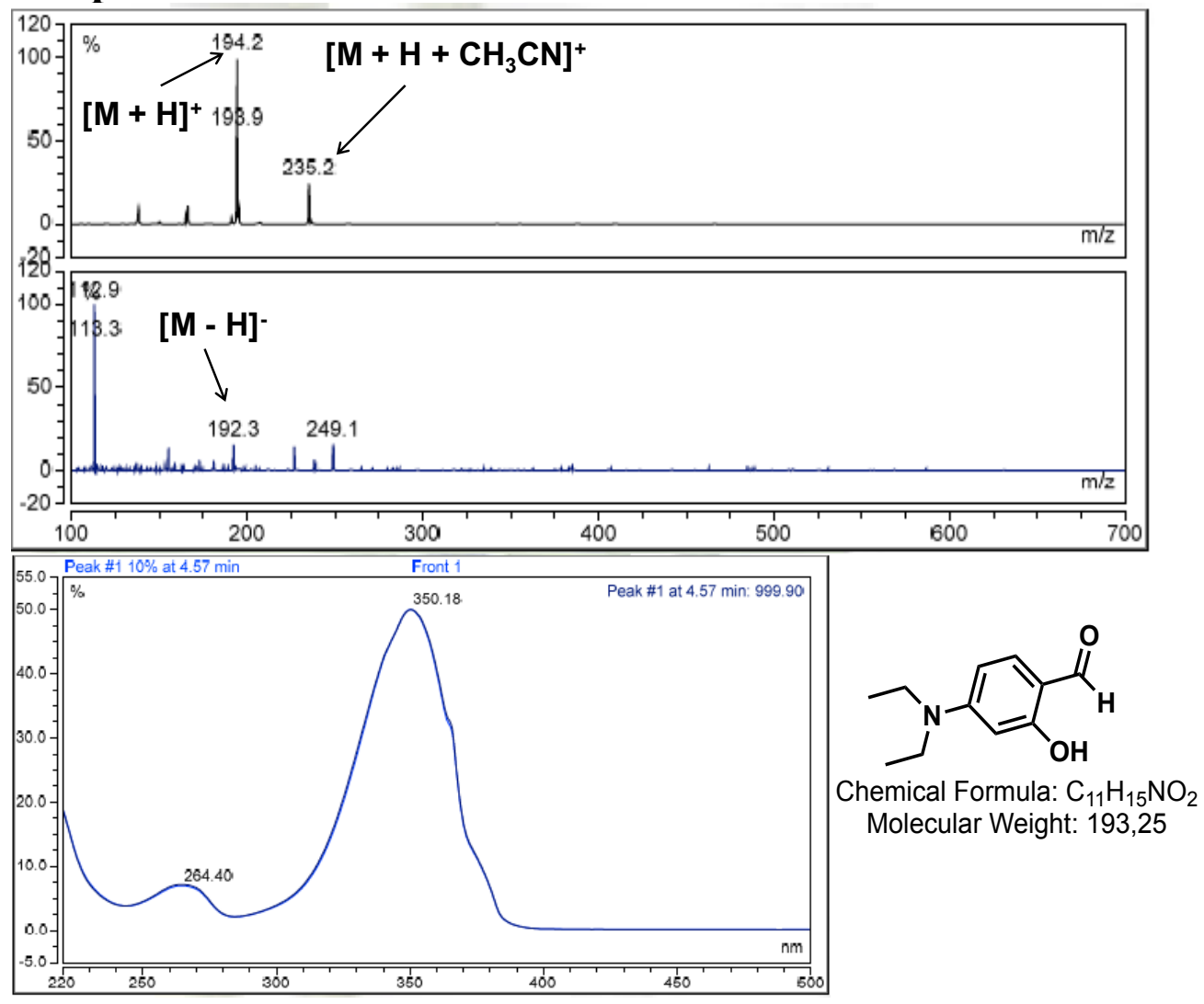

RP-HPLC elution profile of compound 1 (system A, detection at $260 \mathrm{~nm}$ )

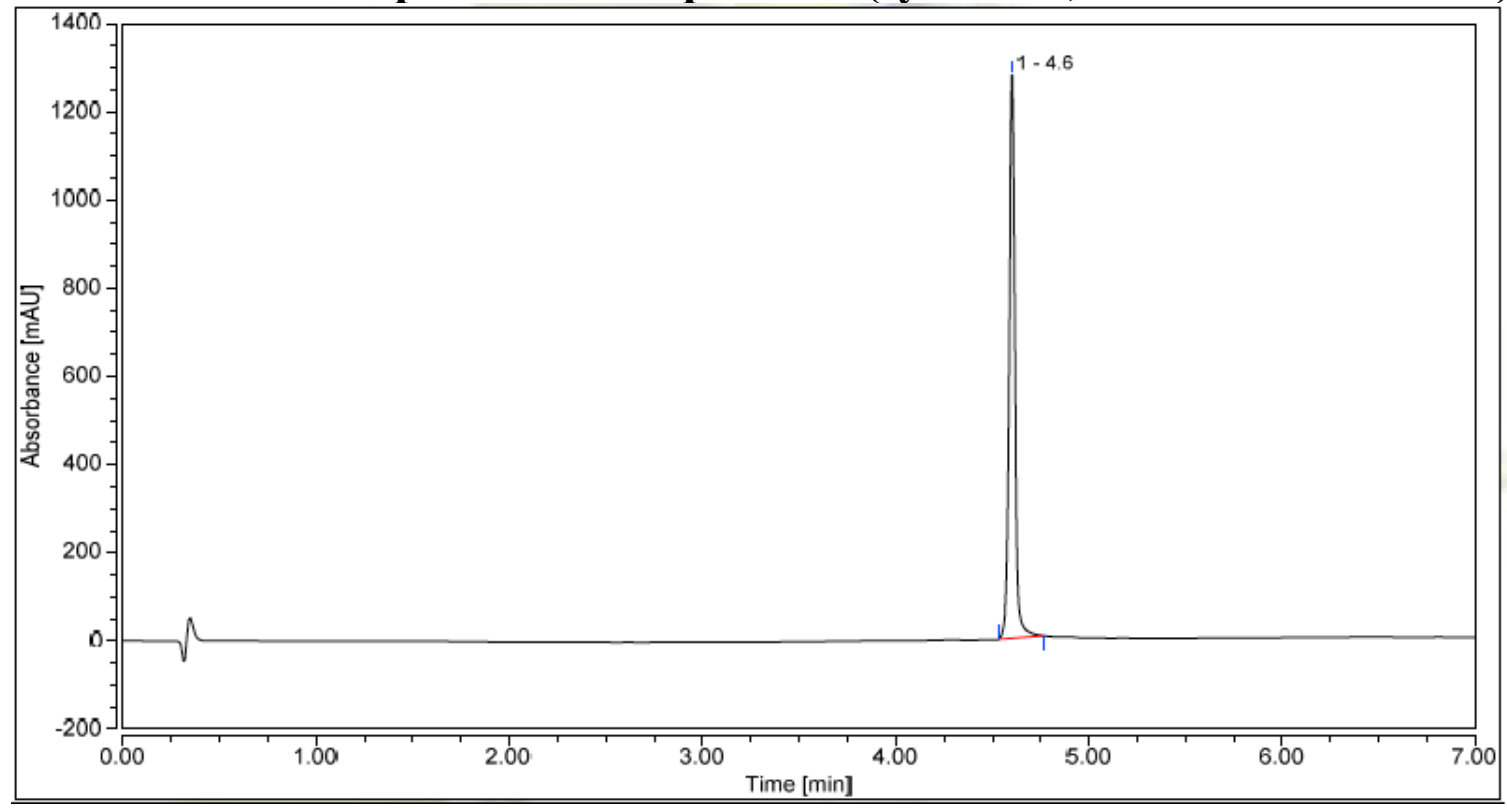


${ }^{1} \mathrm{H}$ NMR spectrum of compound 2 in DMSO- $d_{6}(300 \mathrm{MHz})$

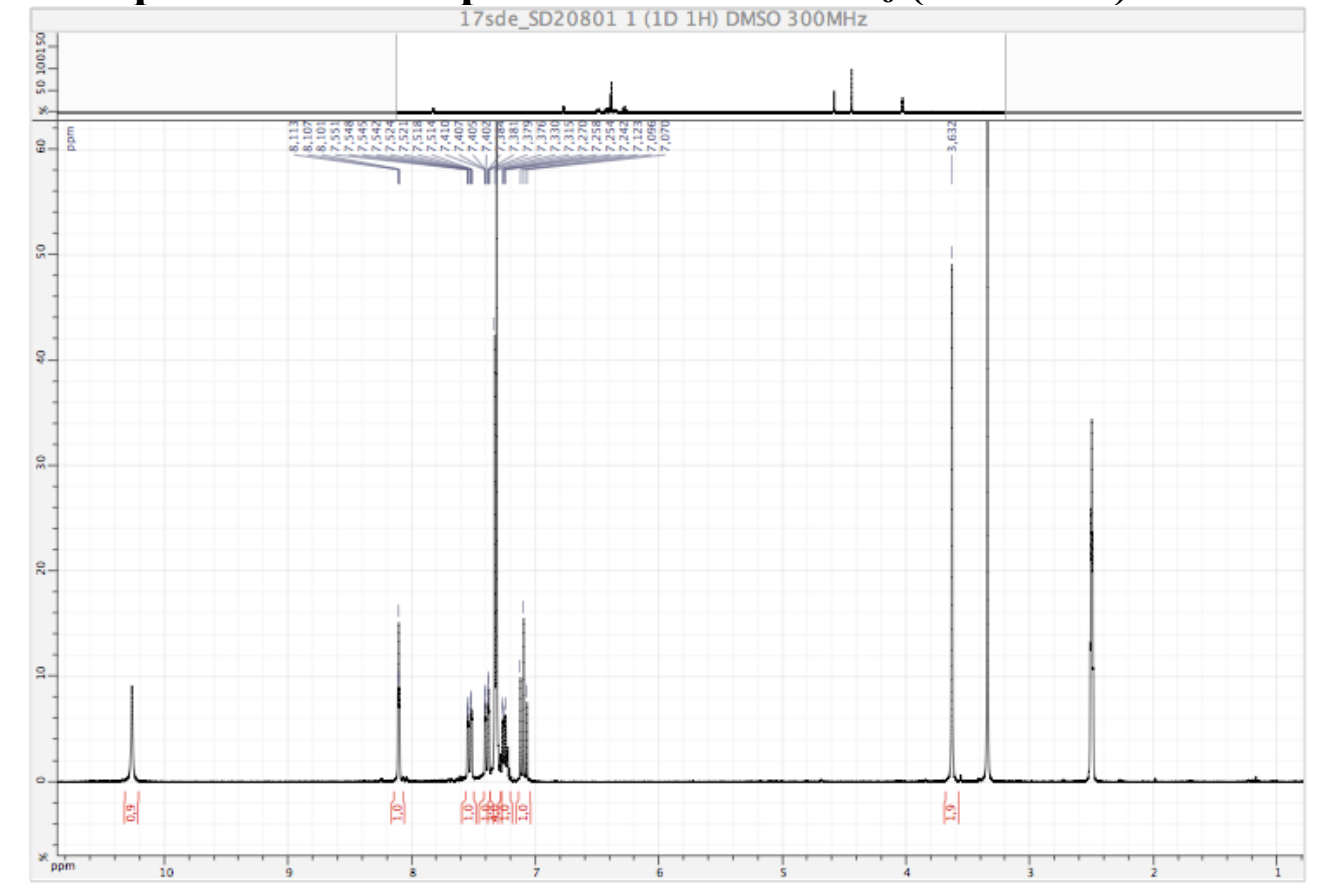

${ }^{13} \mathrm{C}$ NMR spectrum of compound 2 in DMSO- $d_{6}(126 \mathrm{MHz})$

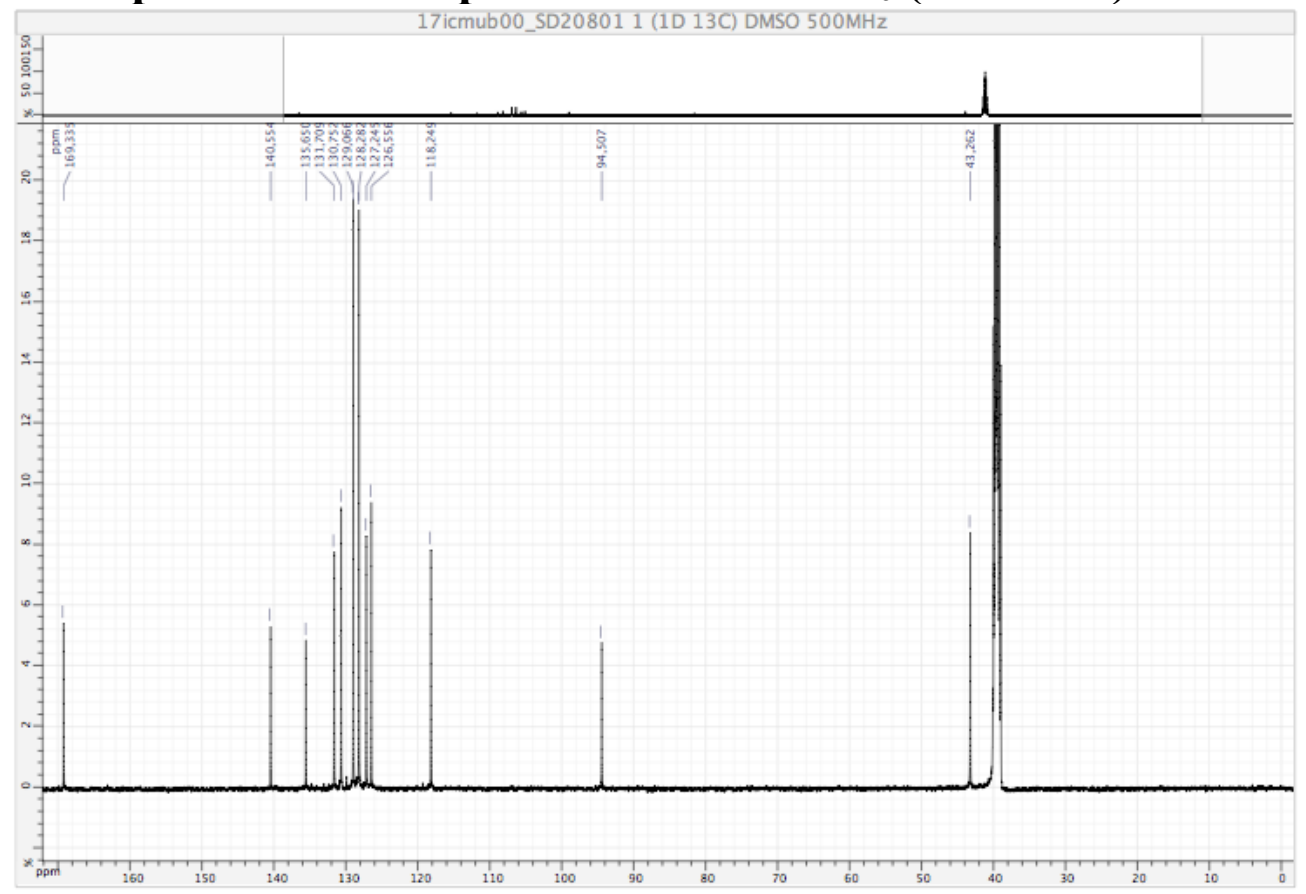


ESI+ / ESI- mass spectra (low resolution) and UV-vis spectrum of compound 2
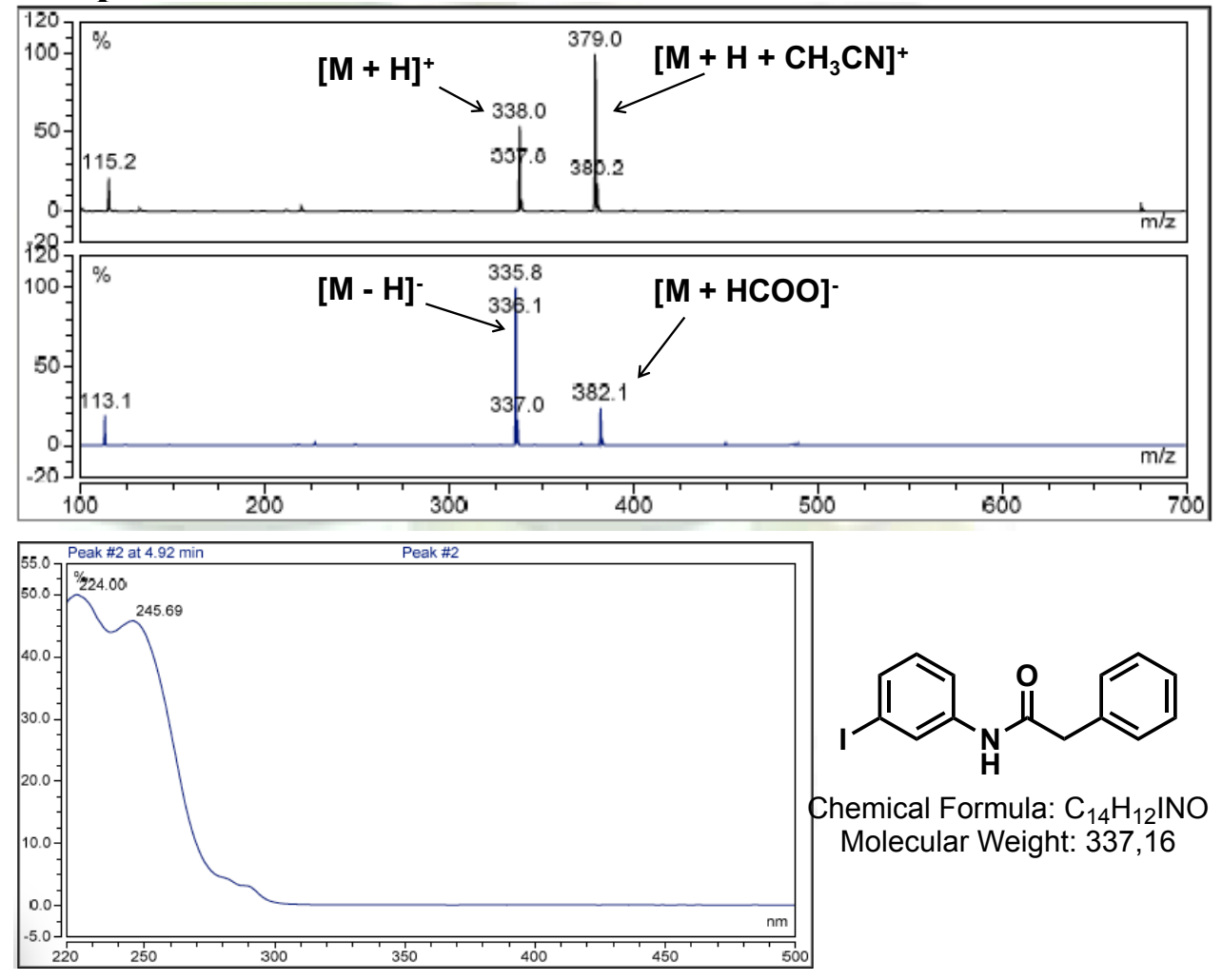

RP-HPLC elution profile of compound 2 (system A, detection at $260 \mathrm{~nm}$ )

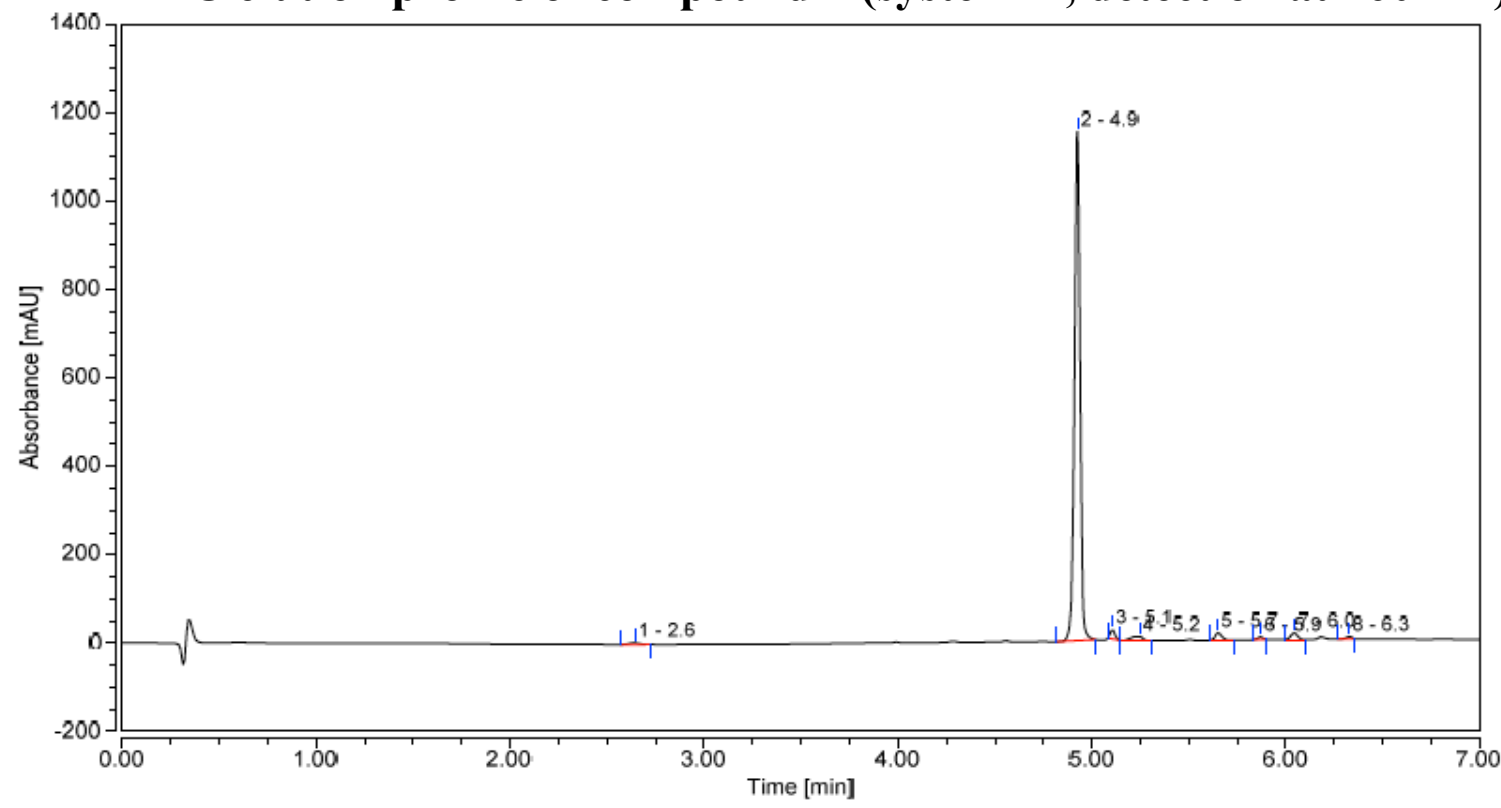




\section{${ }^{1} \mathrm{H}$ NMR spectrum of compound 3 in DMSO- $d_{6}(300 \mathrm{MHz})$}

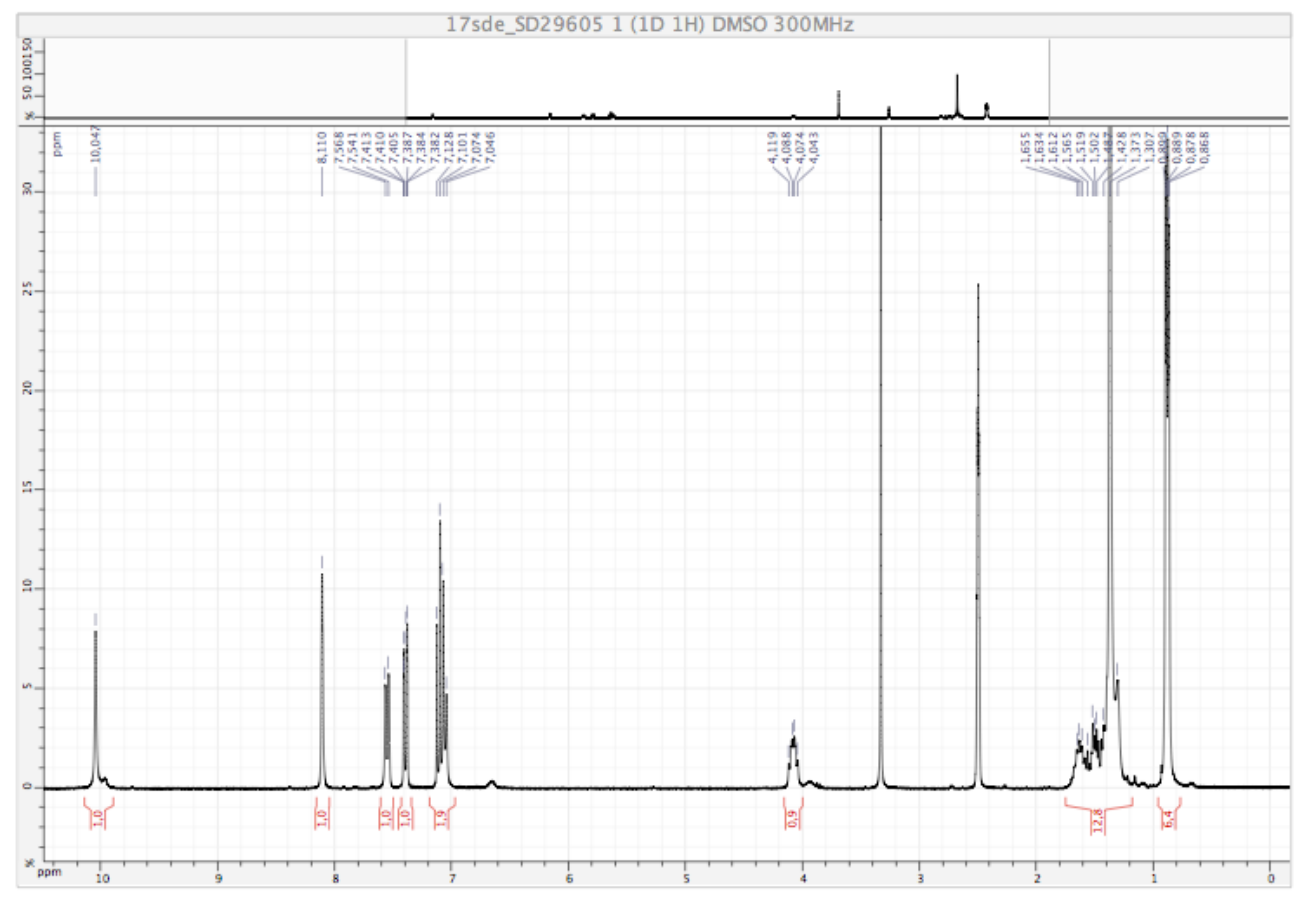

${ }^{13} \mathrm{C}$ NMR spectrum of compound 3 in DMSO- $d_{6}(126 \mathrm{MHz})$

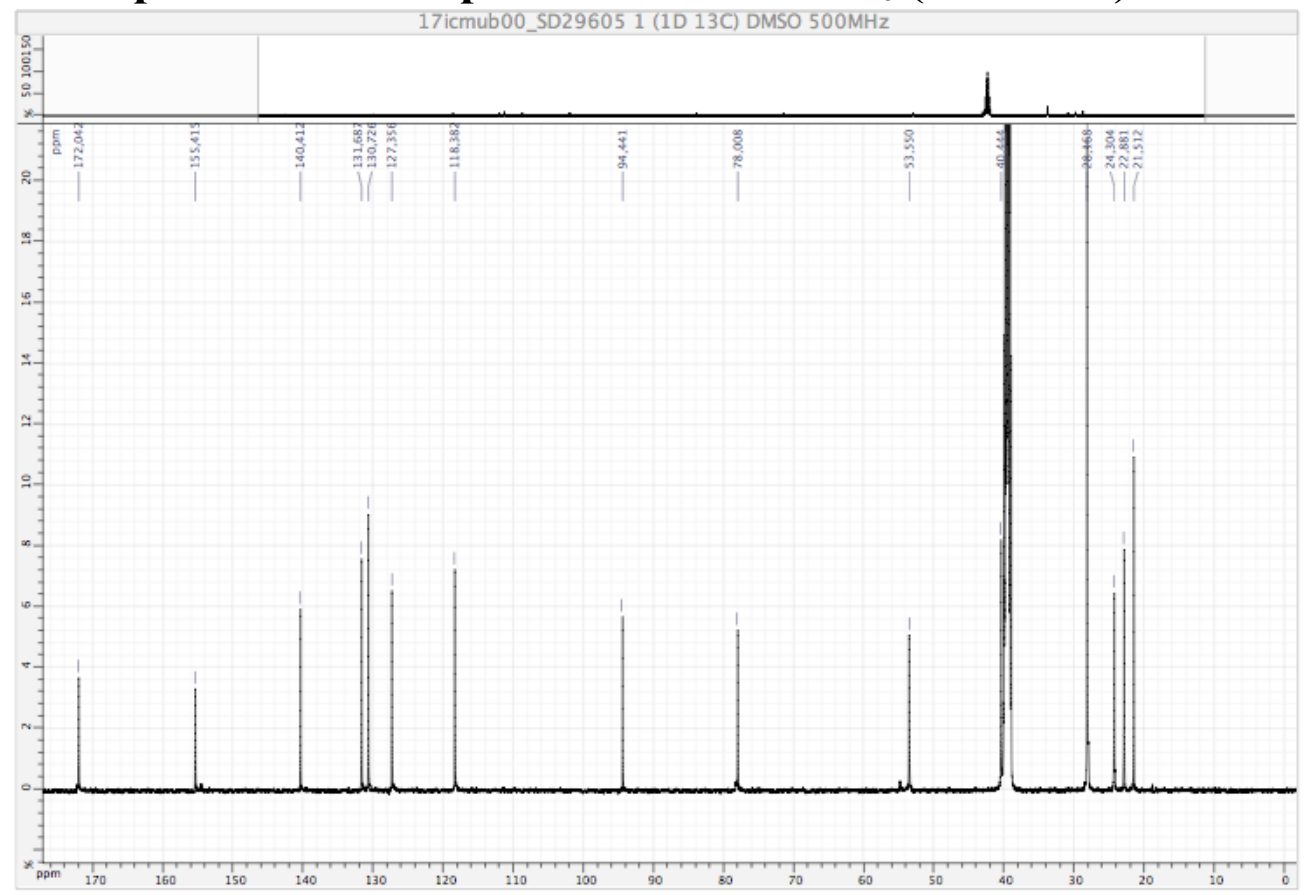


ESI+ / ESI- mass spectra (low resolution) and UV-vis spectrum of compound 3

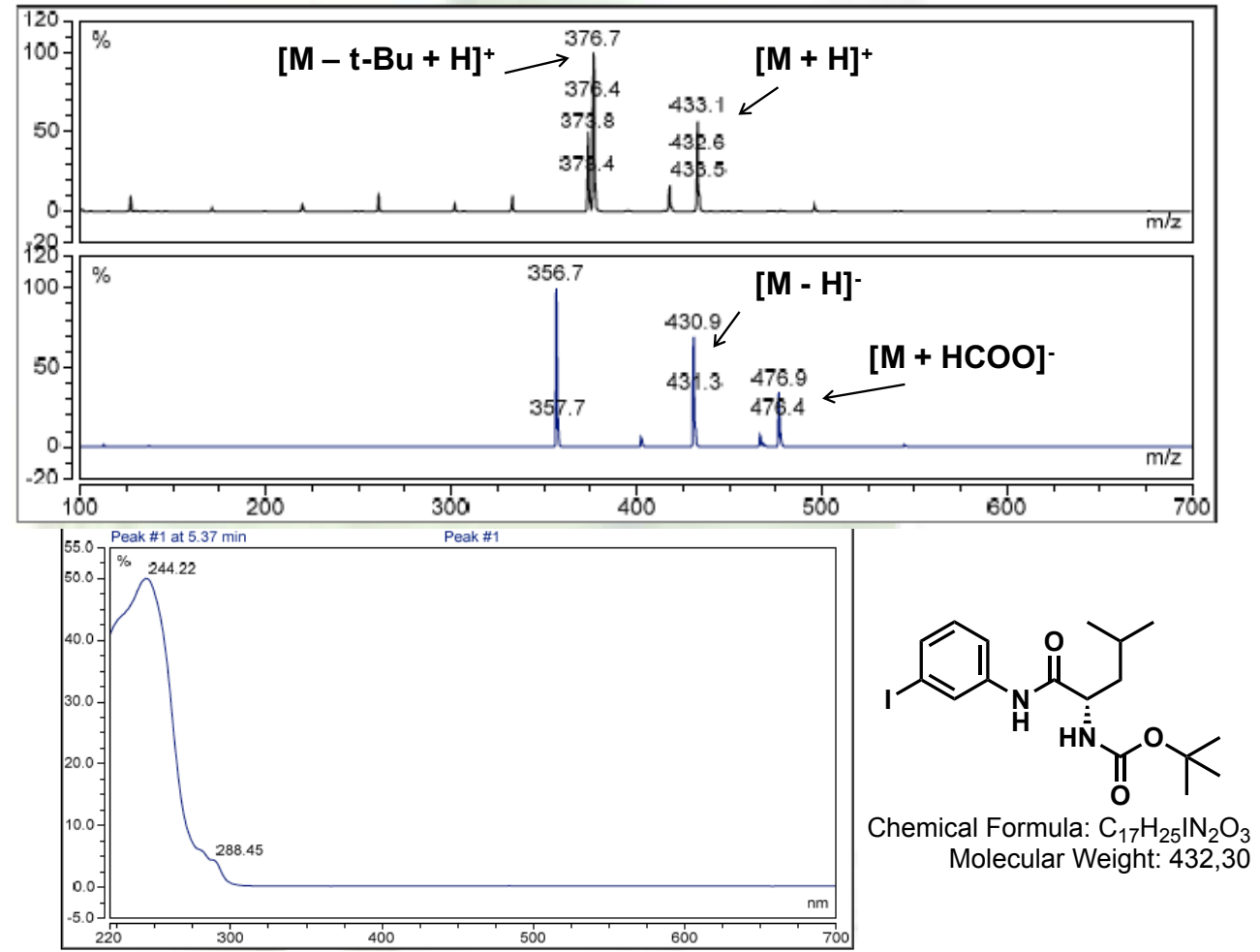

\section{RP-HPLC elution profile of compound 3 (system A, detection at $260 \mathrm{~nm}$ )}

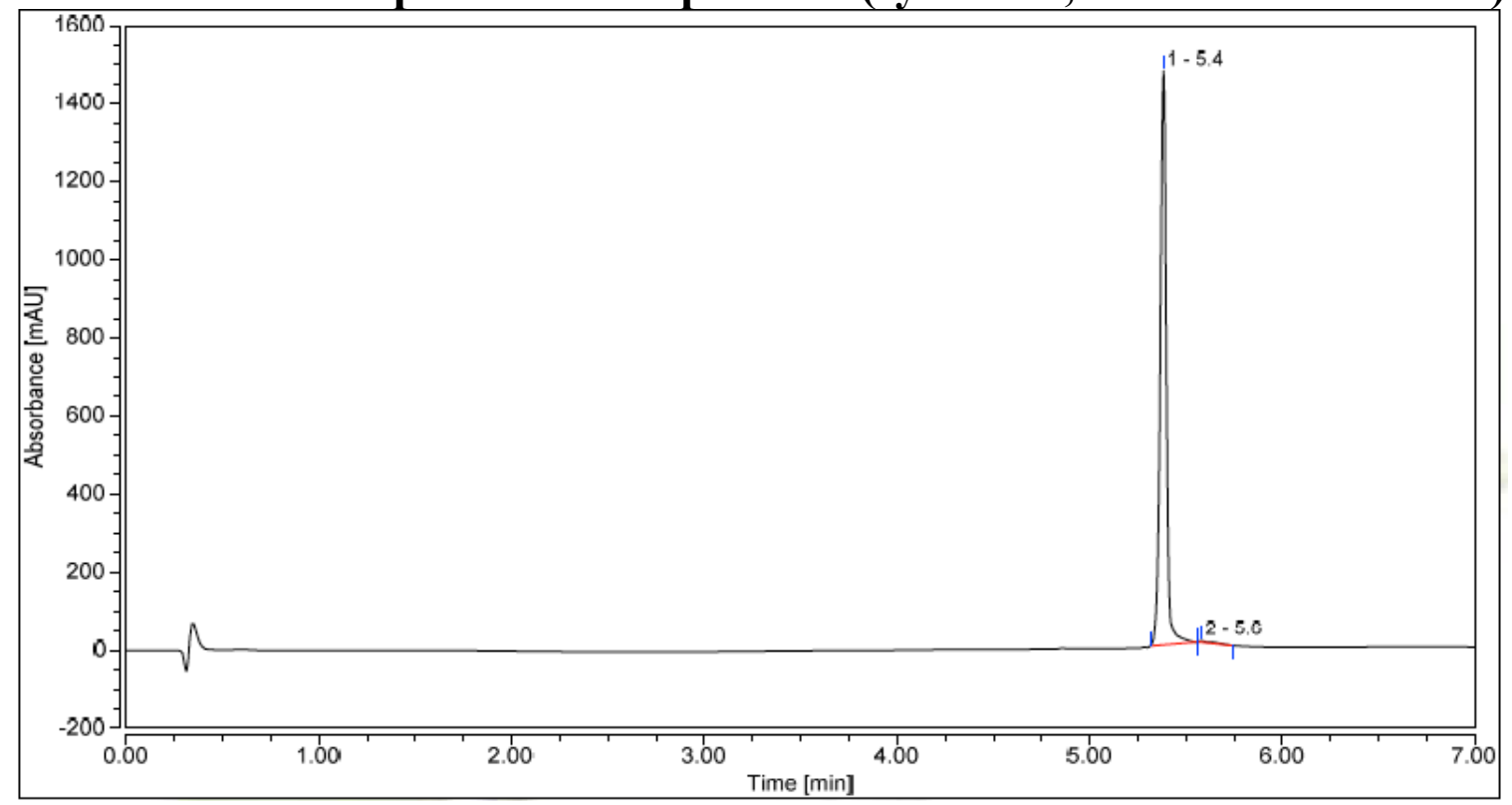




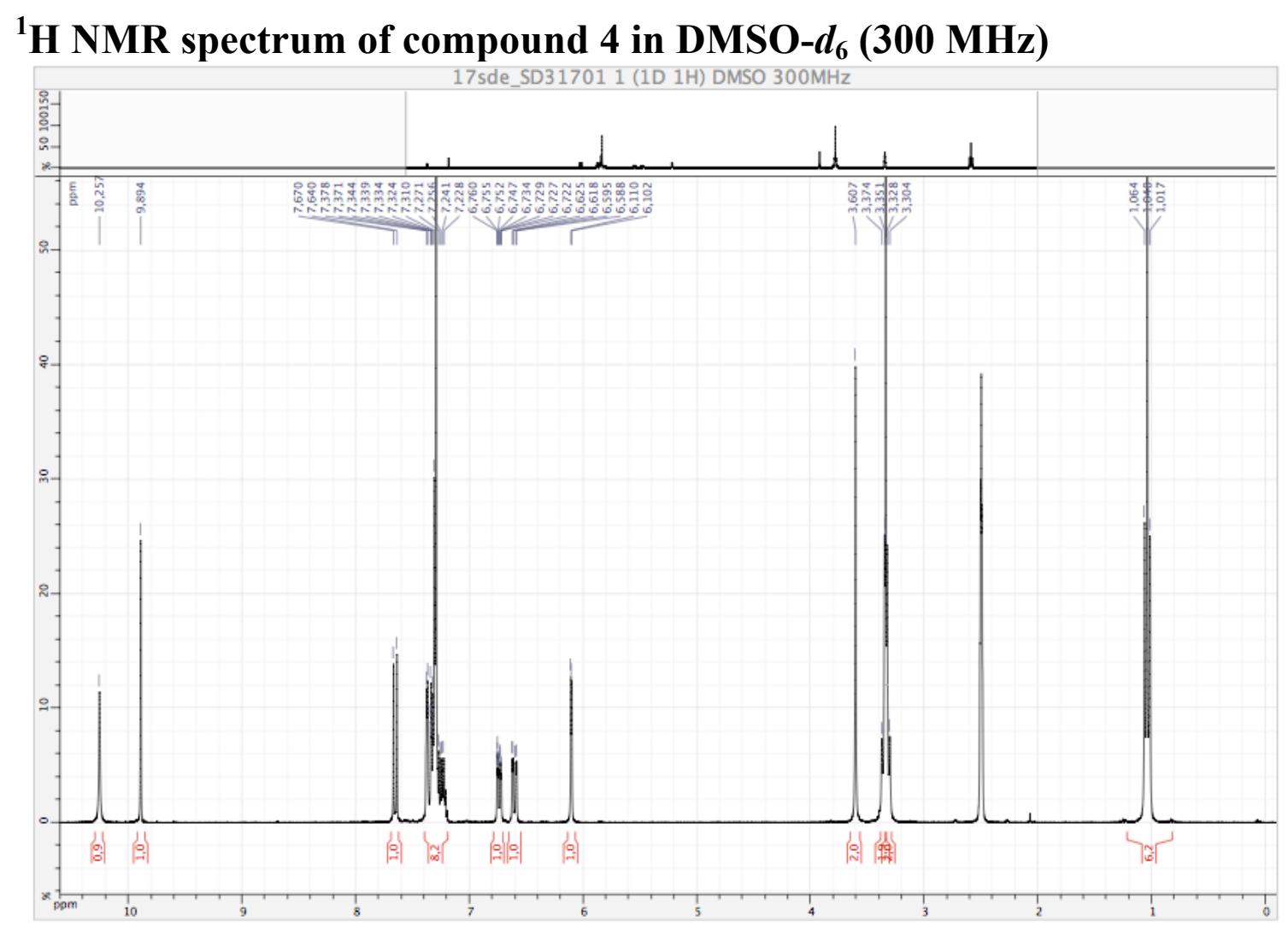

${ }^{13} \mathrm{C}$ NMR spectrum of compound 4 in DMSO- $d_{6}(126 \mathrm{MHz})$

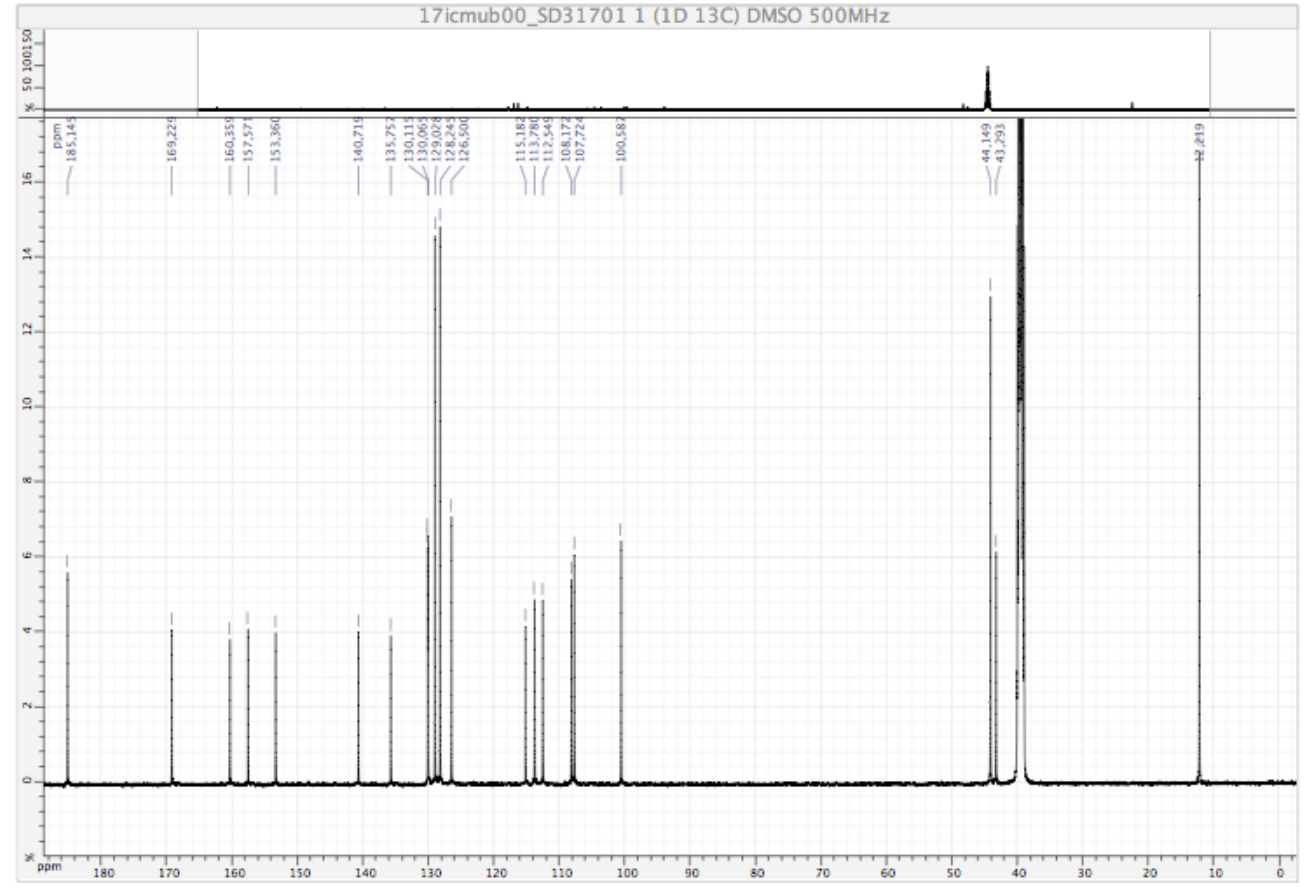


ESI+ / ESI- mass spectra (low resolution) and UV-vis spectrum of compound 4

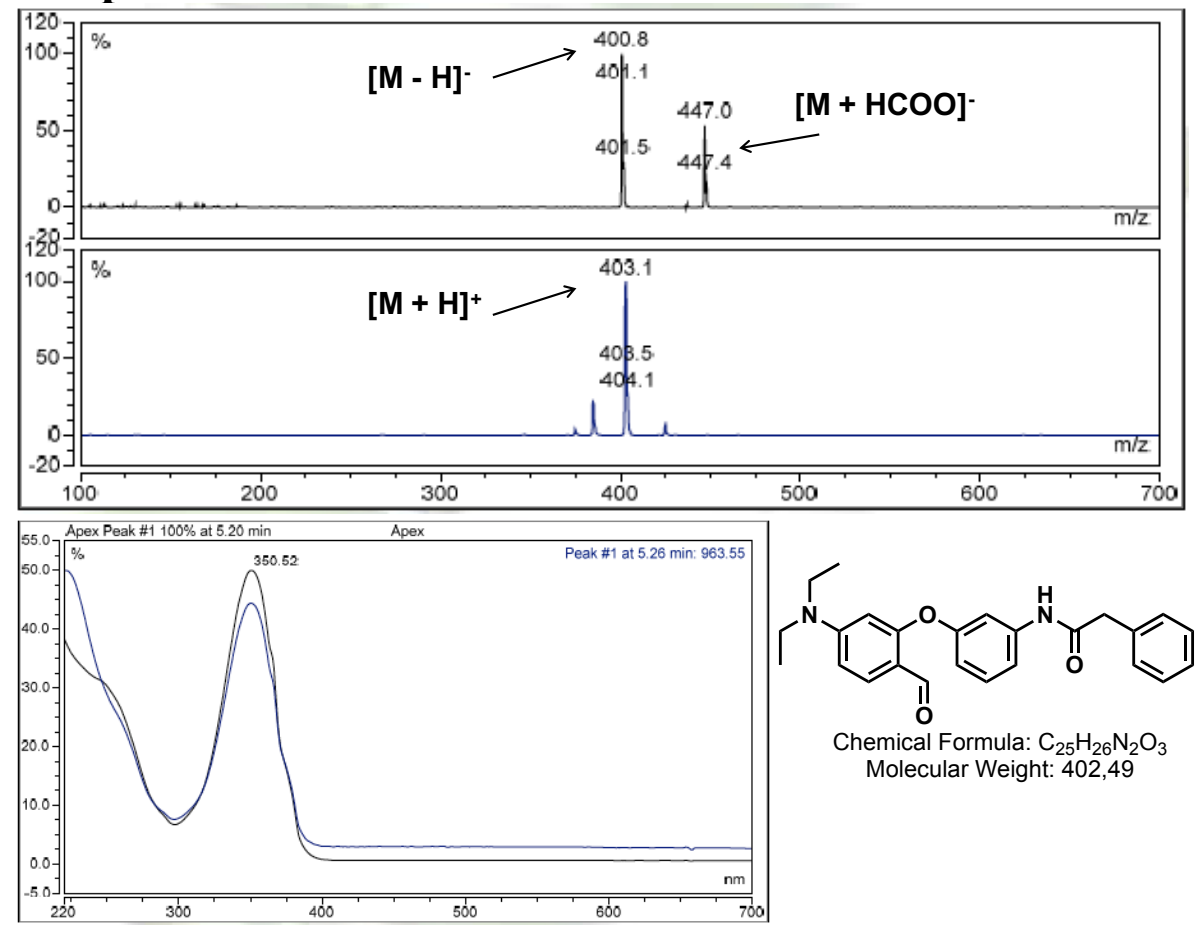

RP-HPLC elution profile of compound 4 (system A, detection at $260 \mathrm{~nm}$ )

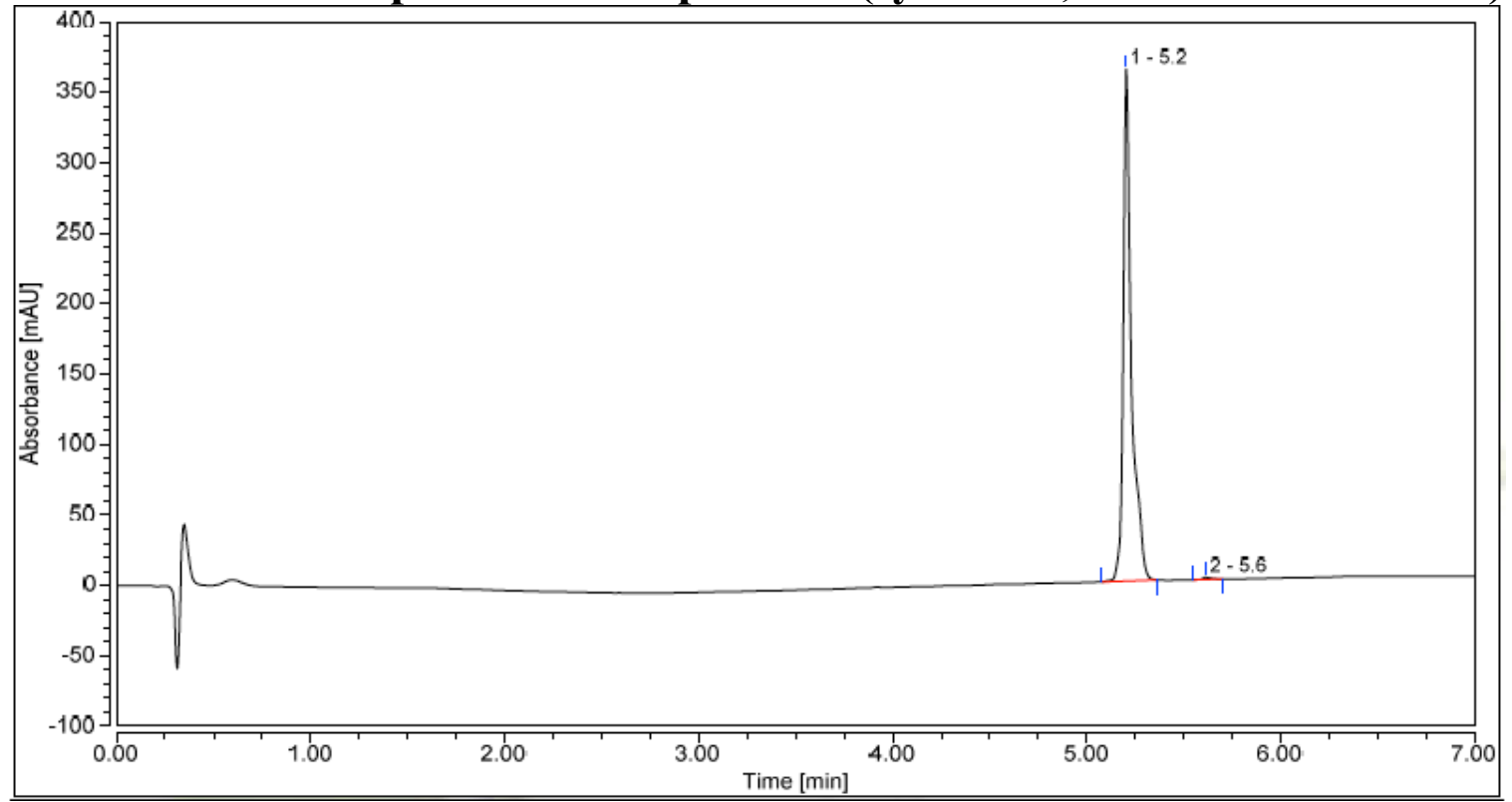




\section{ESI+ mass spectrum (high resolution) of compound 4}

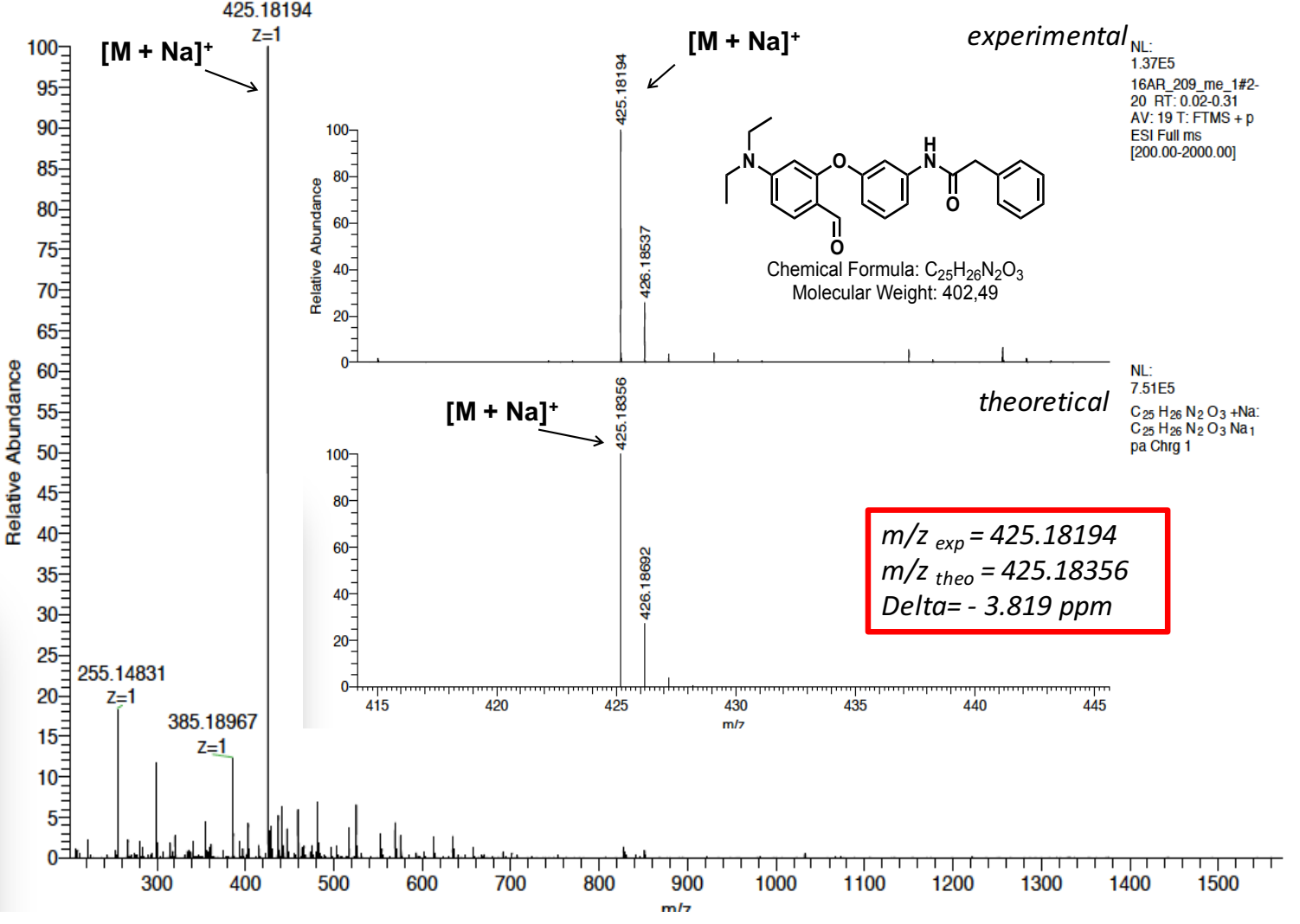




\section{${ }^{1} \mathrm{H}$ NMR spectrum of compound 5 in DMSO- $d_{6}(300 \mathrm{MHz})$}

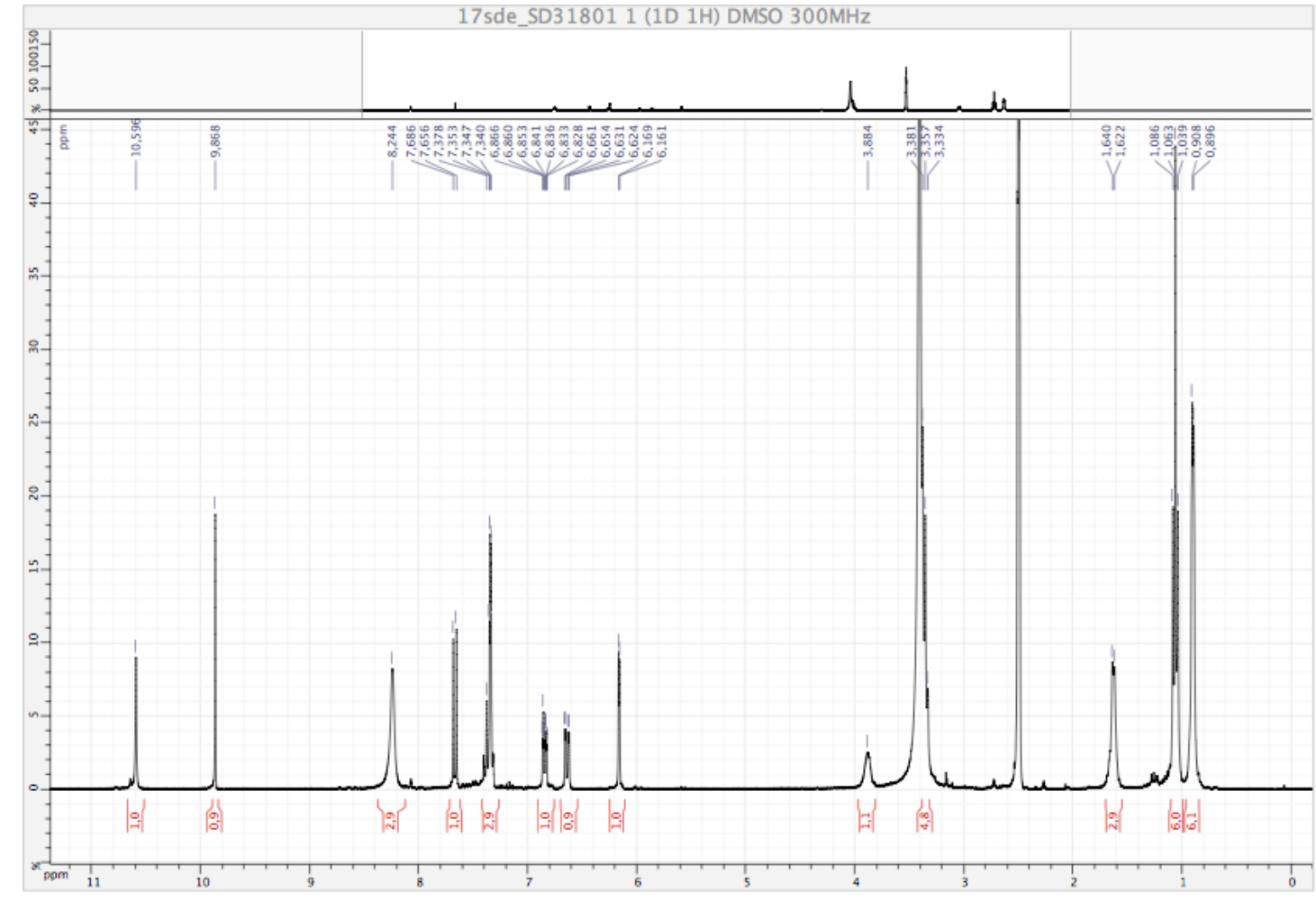

${ }^{13} \mathrm{C}$ NMR spectrum of compound 5 in DMSO- $d_{6}(126 \mathrm{MHz})$

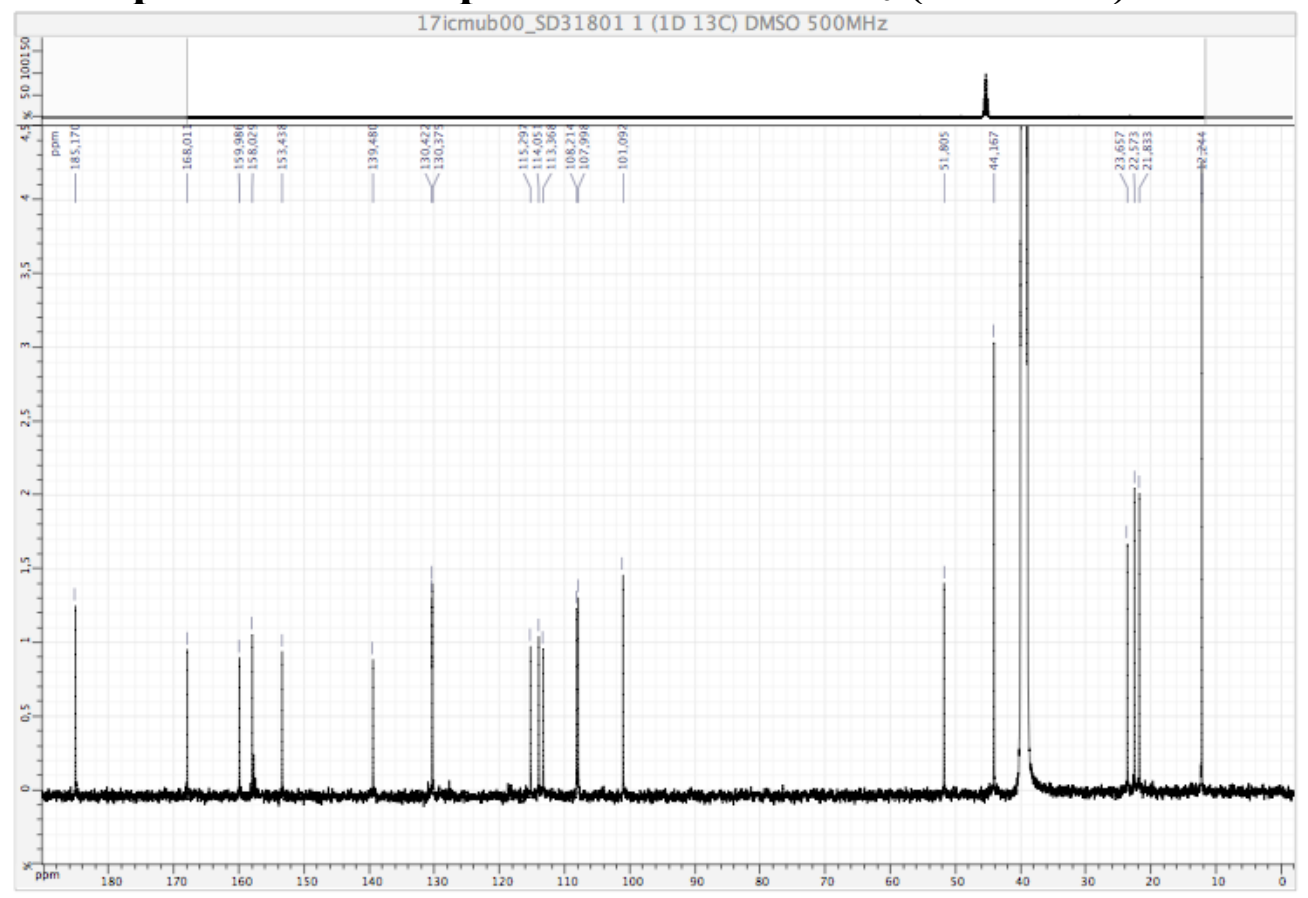




\section{${ }^{19}$ F NMR spectrum of compound 5 in DMSO- $d_{6}(470 \mathrm{MHz})$}

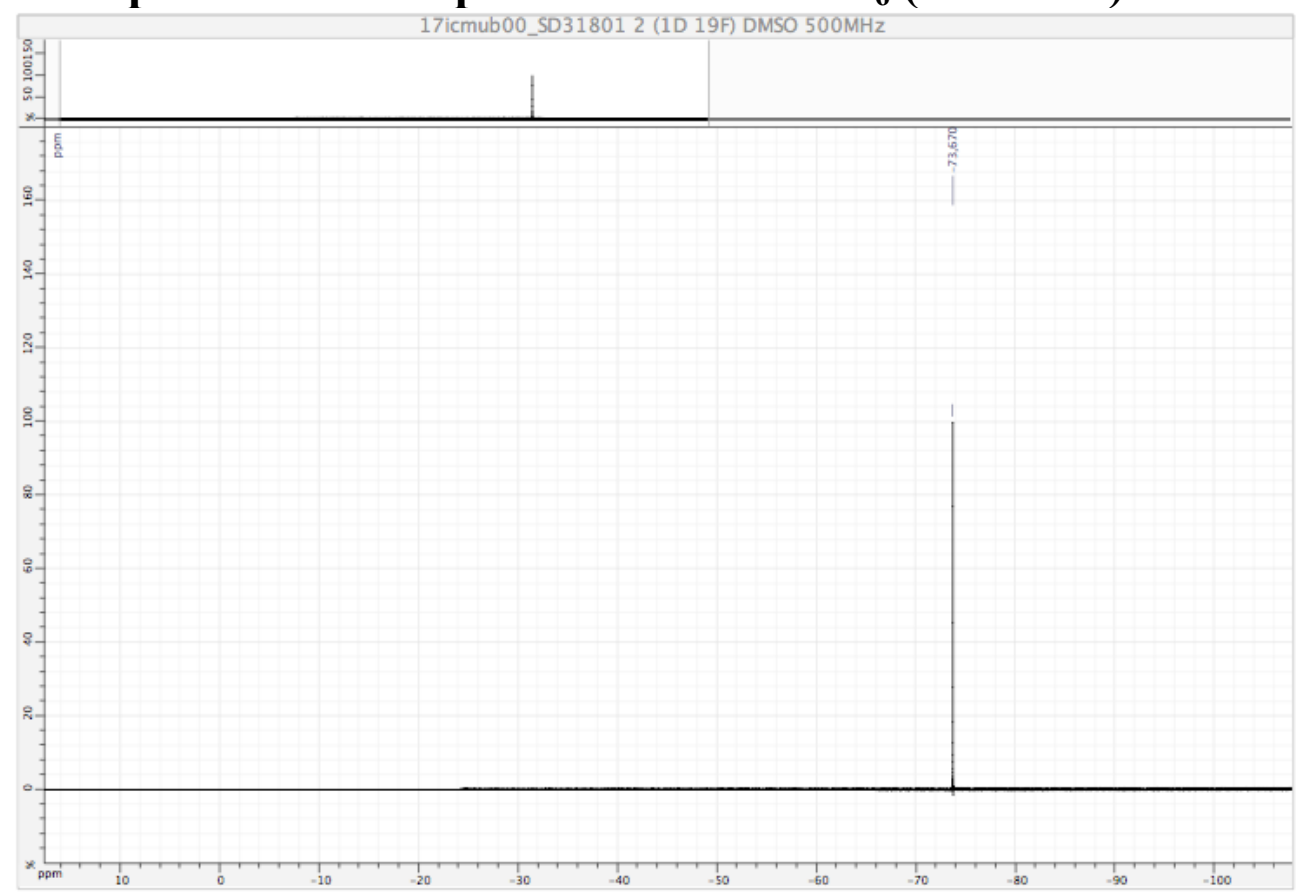

ESI+ / ESI- mass spectra (low resolution) and UV-vis spectrum of compound 5

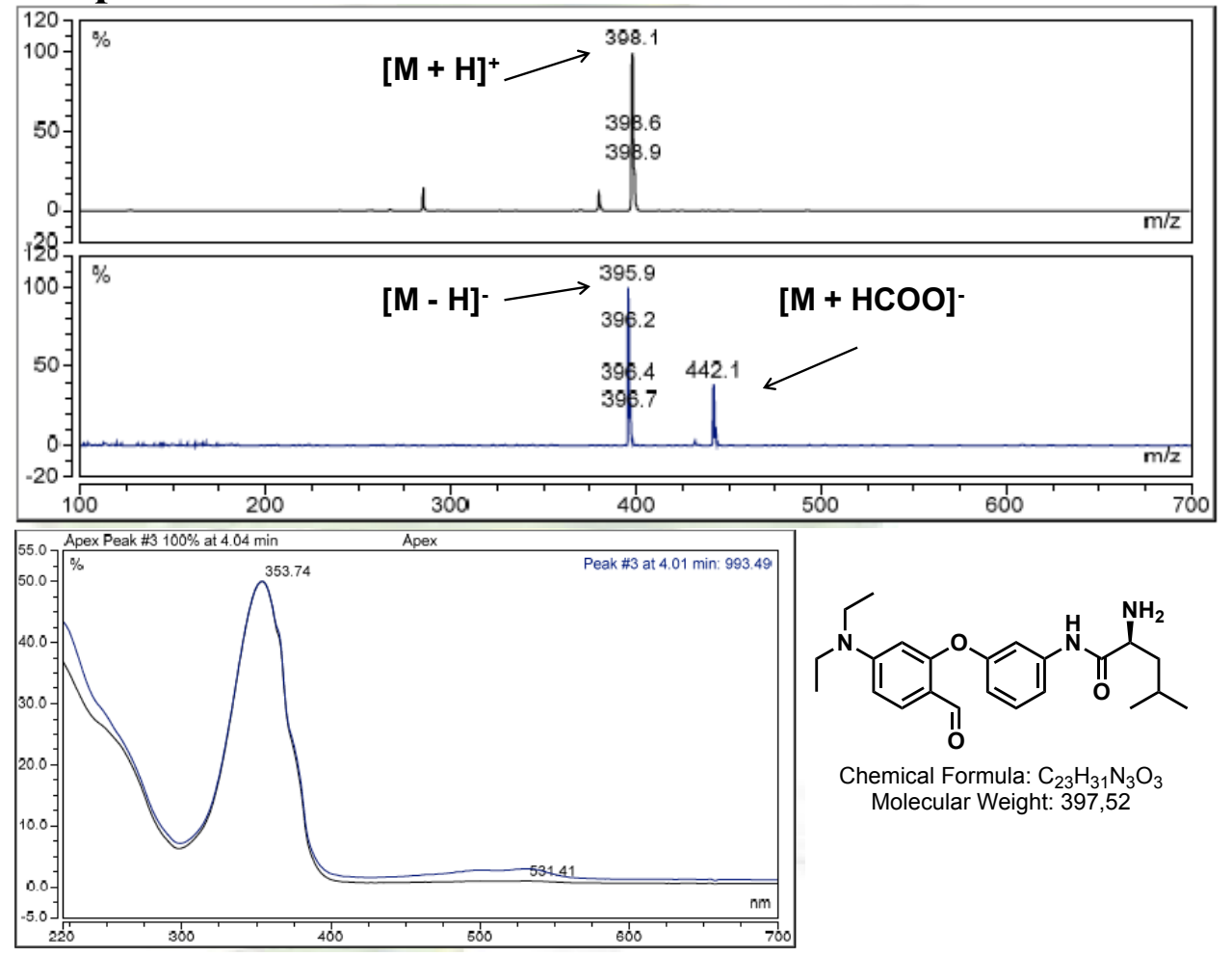




\section{RP-HPLC elution profile of compound 5 (system A, detection at $260 \mathrm{~nm}$ )}

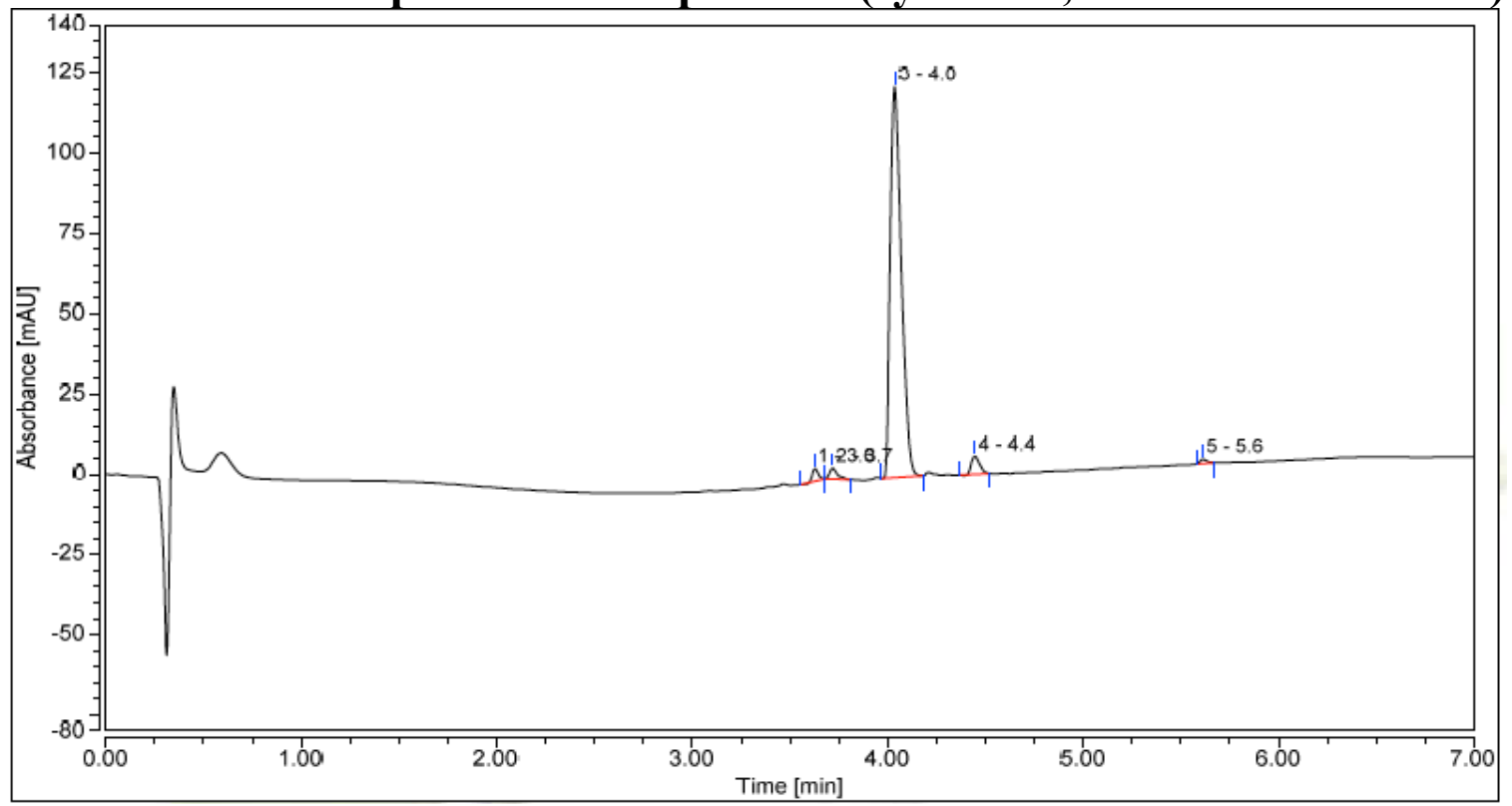

\section{ESI+ mass spectrum (high resolution) of compound 5}

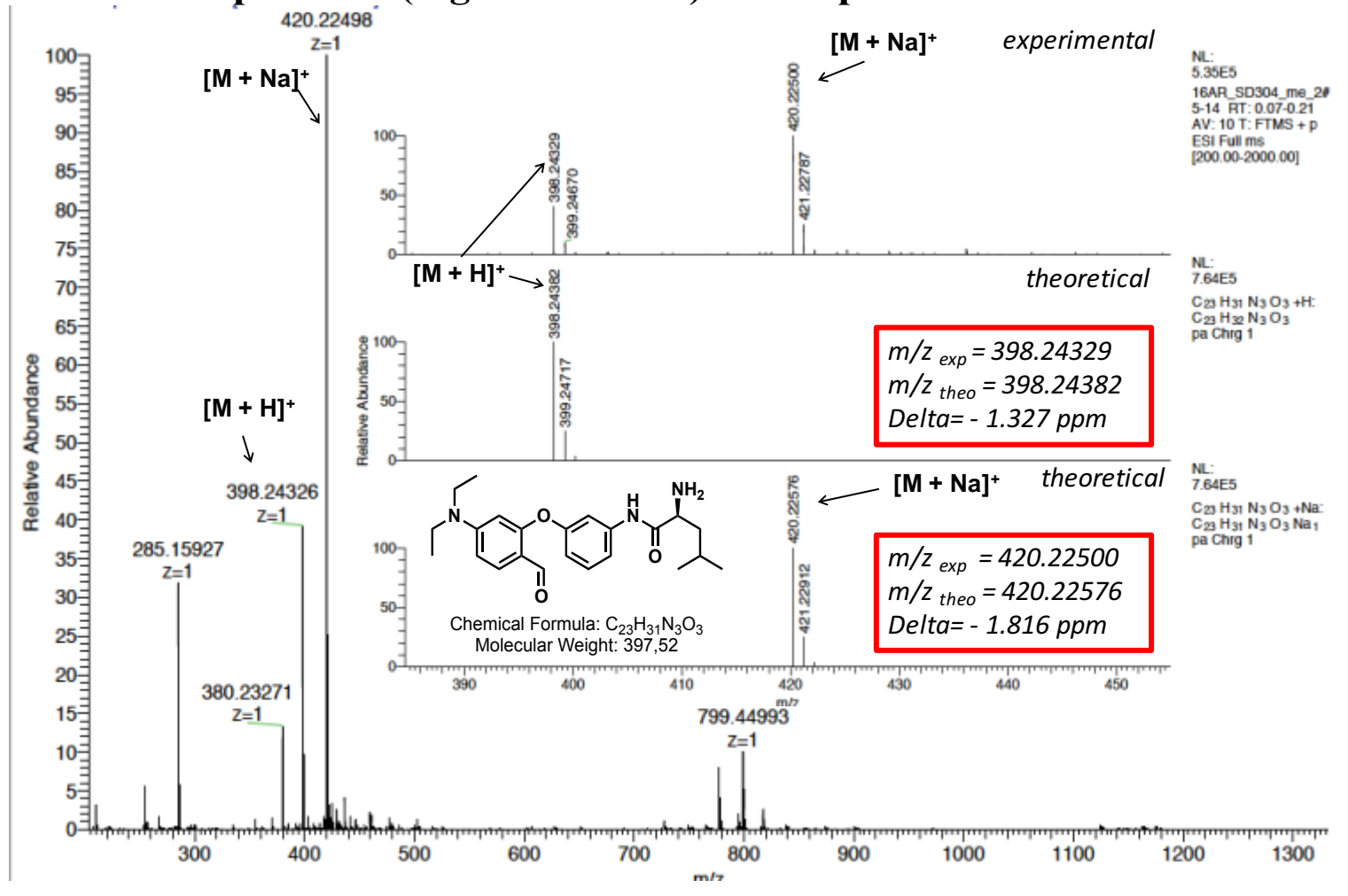




\section{${ }^{1} \mathrm{H}$ NMR spectrum of 6 in $\mathrm{CD}_{3} \mathrm{OD}(500 \mathrm{MHz})$}

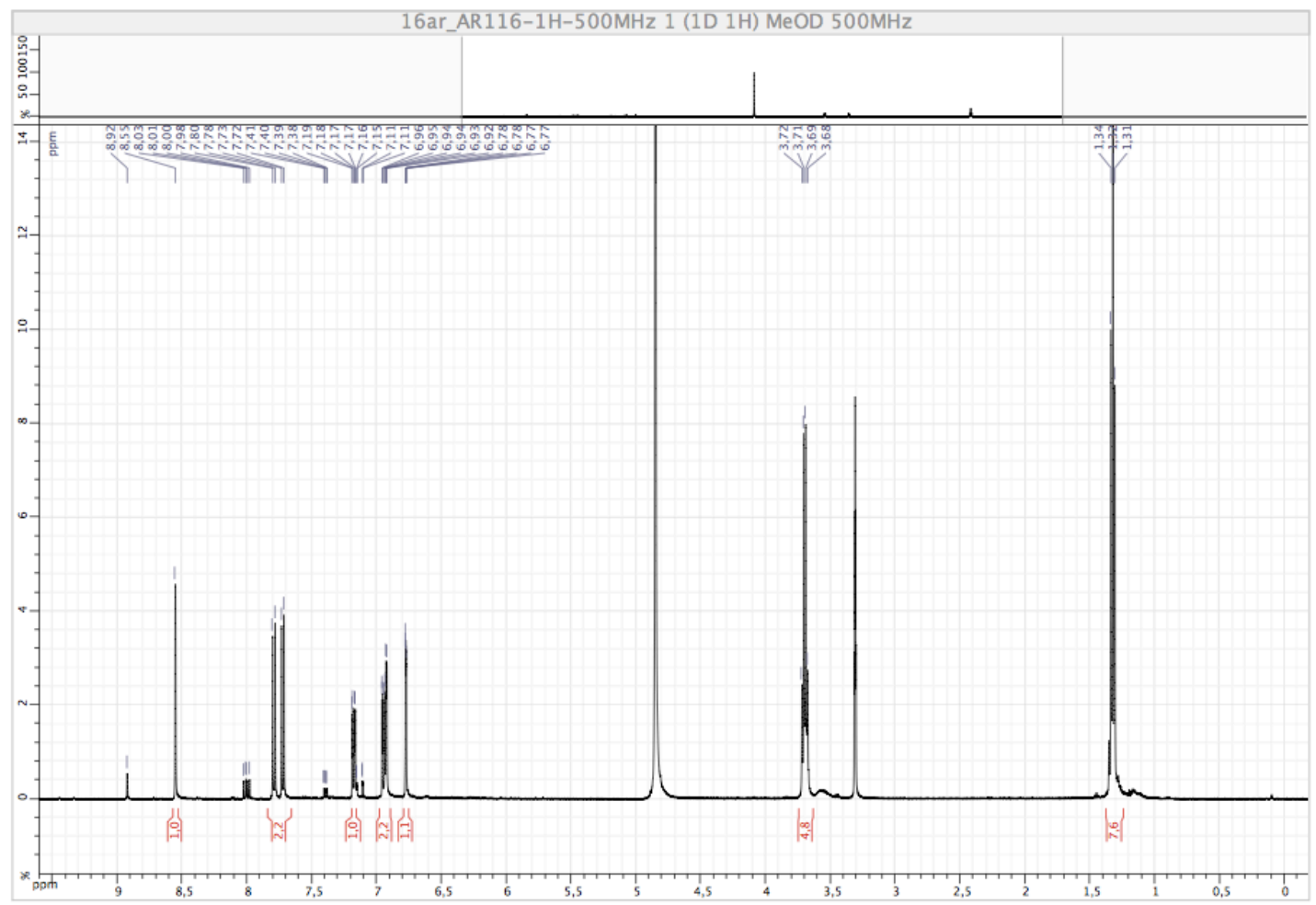

${ }^{13} \mathrm{C}$ NMR spectrum of 6 in $\mathrm{CD}_{3} \mathrm{OD}(126 \mathrm{MHz})$

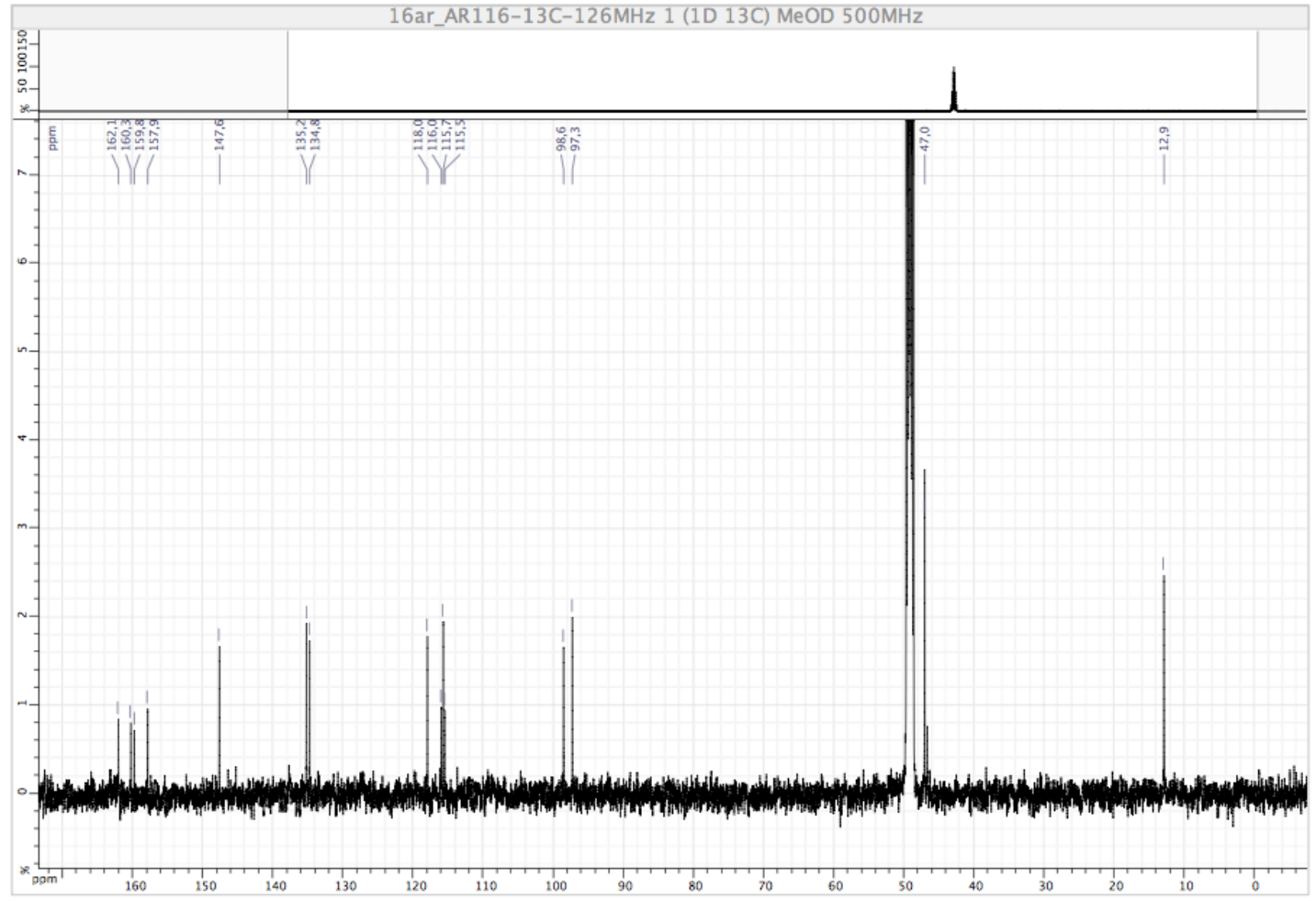




\section{${ }^{19}$ F NMR spectrum of 6 in $\mathrm{CD}_{3} \mathrm{OD}(470 \mathrm{MHz})$}

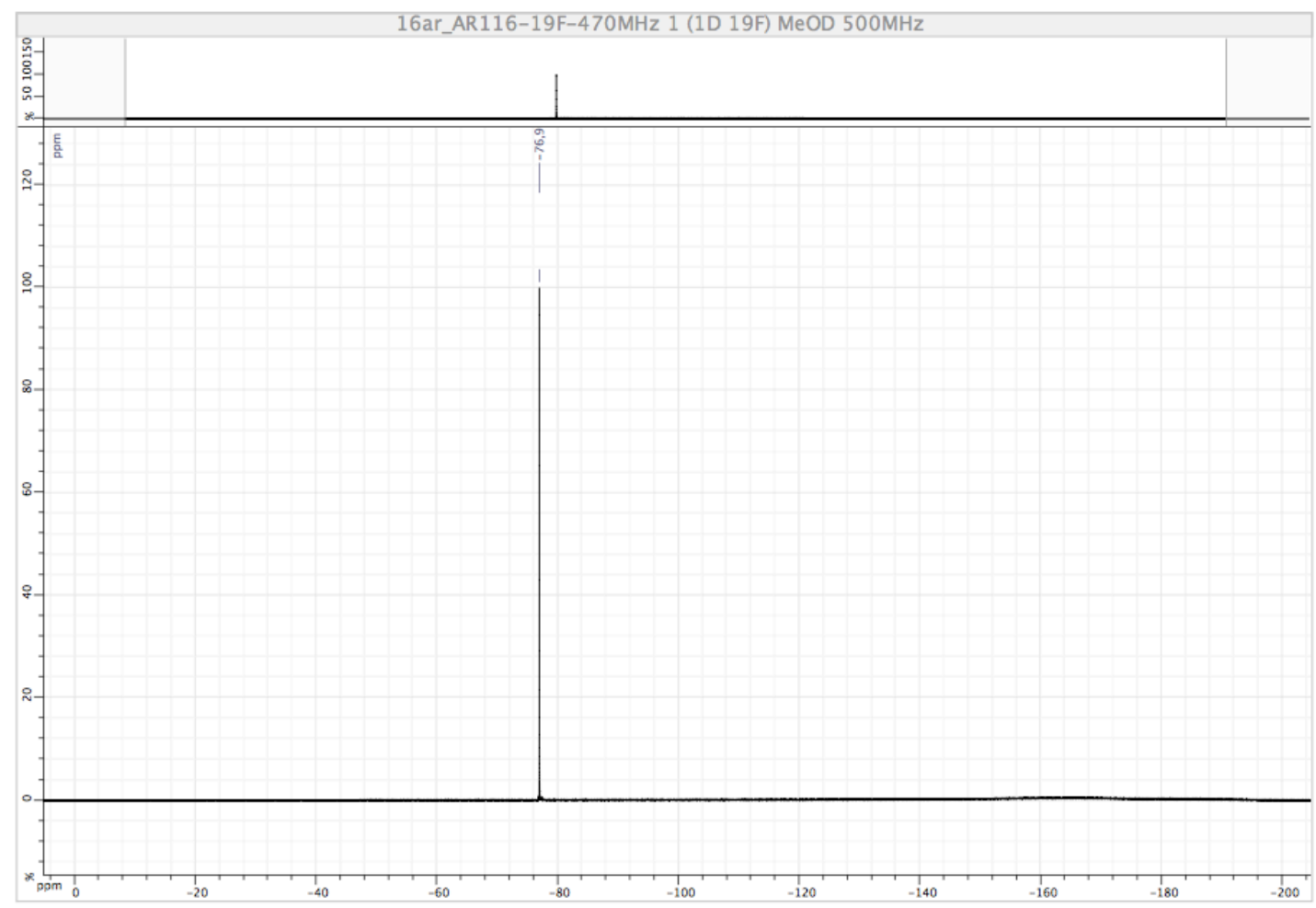

ESI+ / ESI- mass spectrum (low resolution) and UV-vis spectrum of compound 6

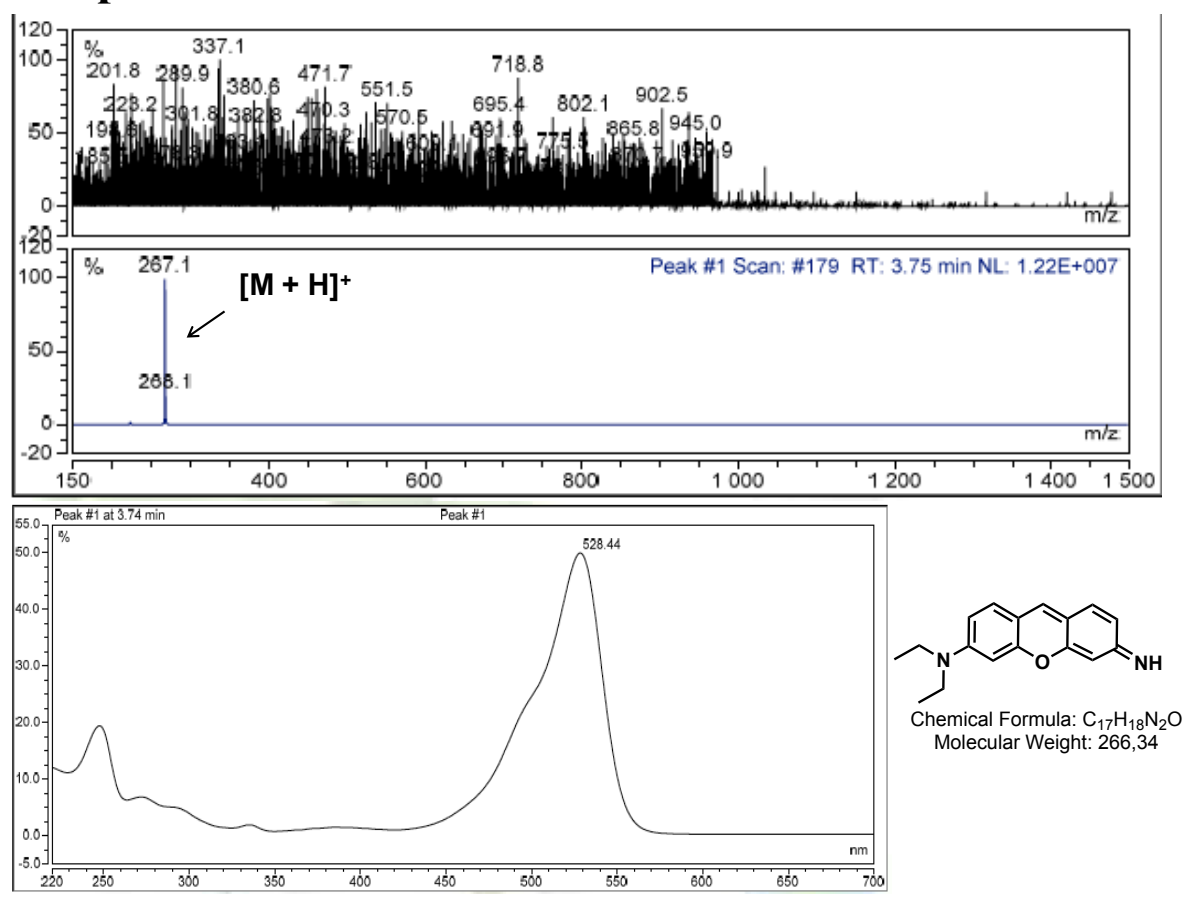


RP-HPLC elution profile of compound 6 (system B, detection at $260 \mathrm{~nm}$ )

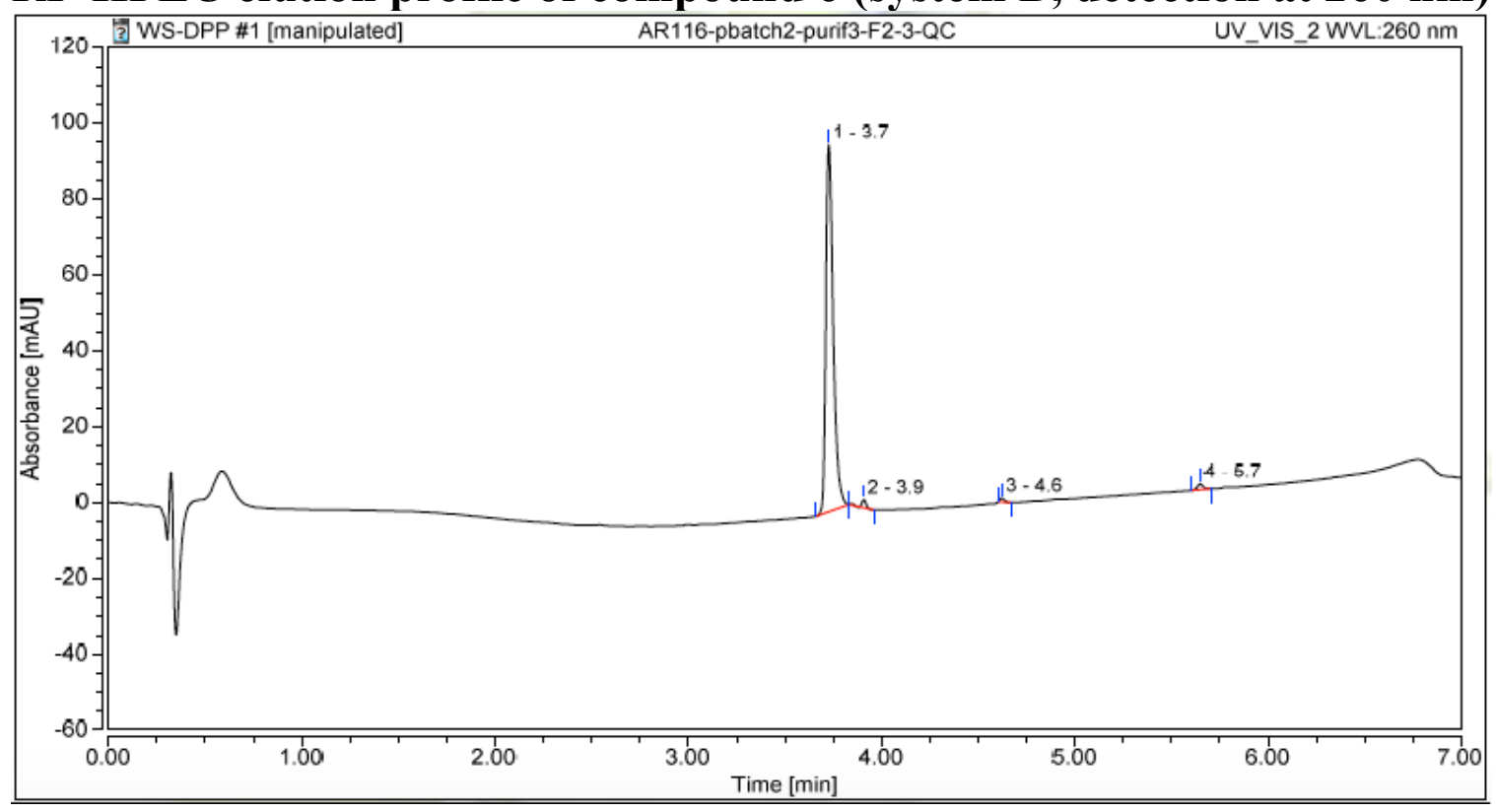

RP-HPLC elution profile of compound 6 (system B, detection at $500 \mathrm{~nm}$ )

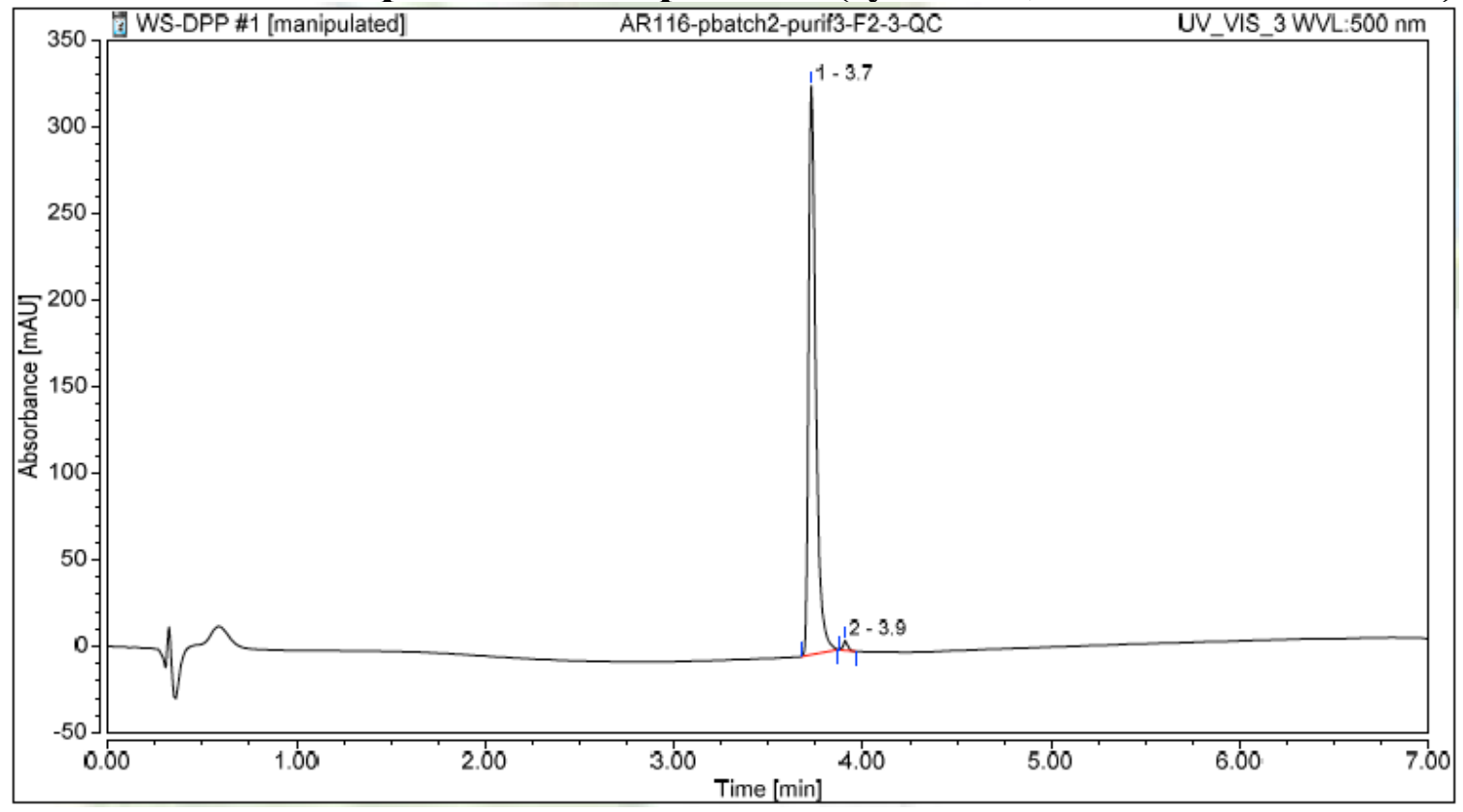


Fig. S1 Normalised UV-vis absorption spectra of fluorogenic probes 4 and 5 in $\mathrm{PB}\left(+0.3 \% \mathrm{CH}_{3} \mathrm{CN}\right.$ and $0.15 \% \mathrm{CH}_{3} \mathrm{CN}$ respectively) at $25^{\circ} \mathrm{C}$.

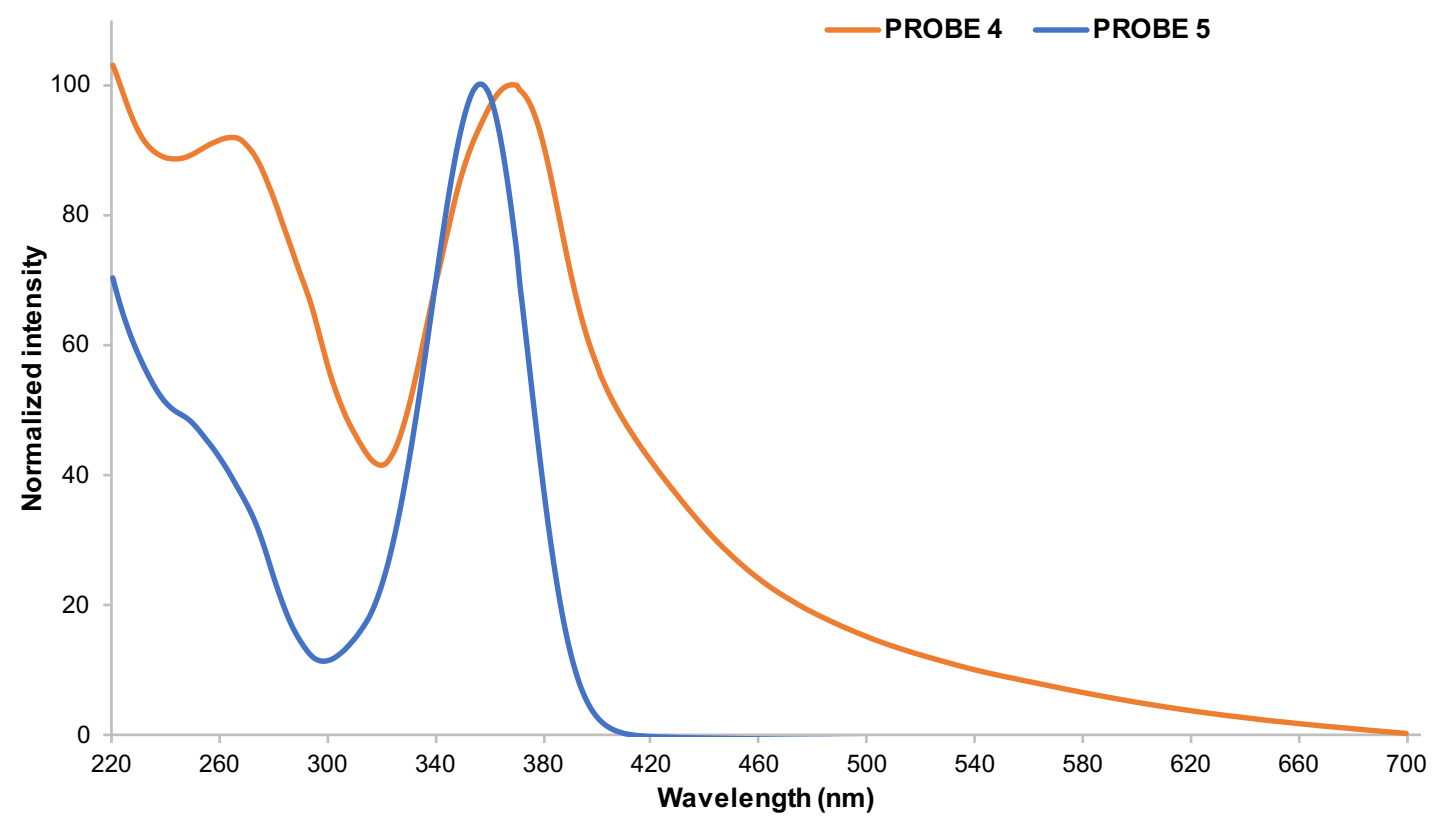

Fig. S2 Normalised absorption, excitation (Em. $545 \mathrm{~nm})$ and emission (Ex. $460 \mathrm{~nm}$ ) spectra of the pyronin 6 in $\mathrm{PB}$ at $25^{\circ} \mathrm{C}$.

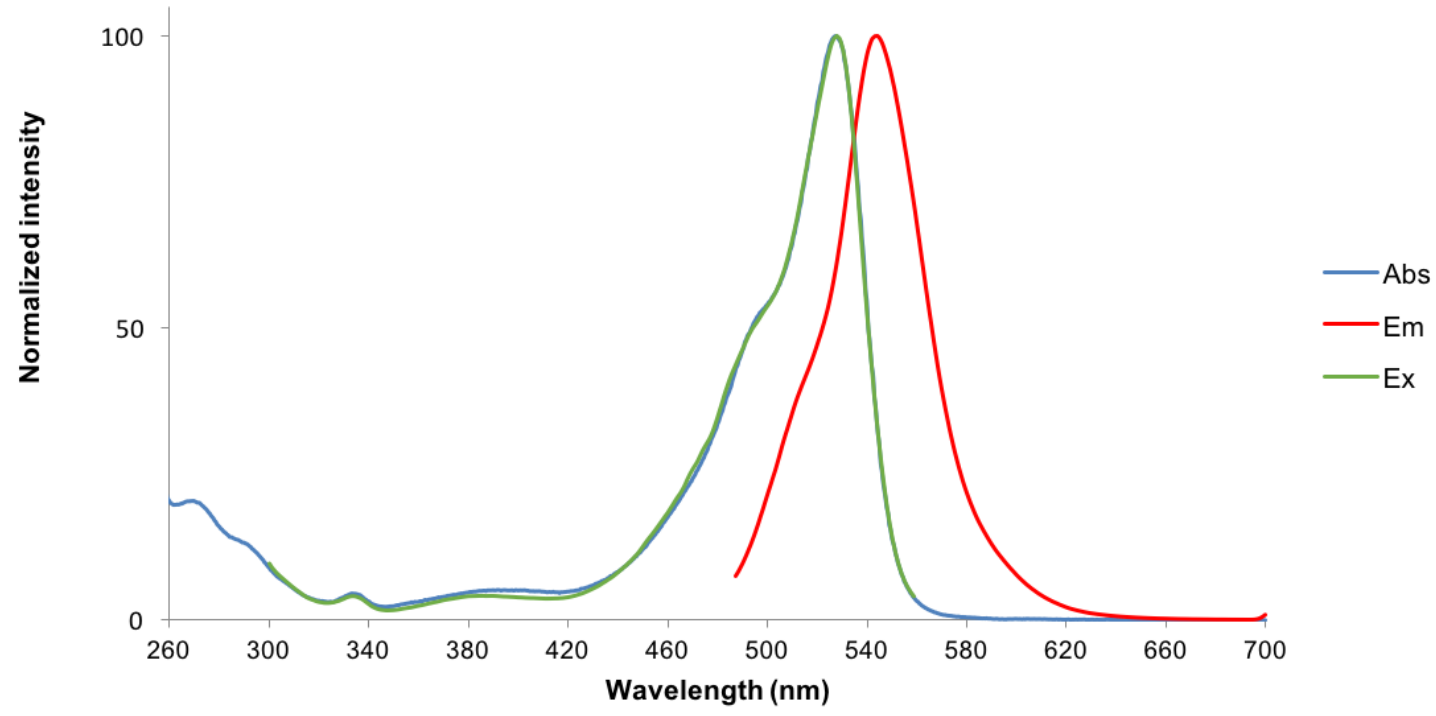


Fig. S3 Overlayed fluorescence emission spectra (Ex. $460 \mathrm{~nm})$ of PGAfluorogenic probe 4, LAP-fluorogenic probe 5 and pyronin 6 in PB at 25 ${ }^{\circ} \mathrm{C}$ (concentration: $\left.1 \mu \mathrm{M}\right)$

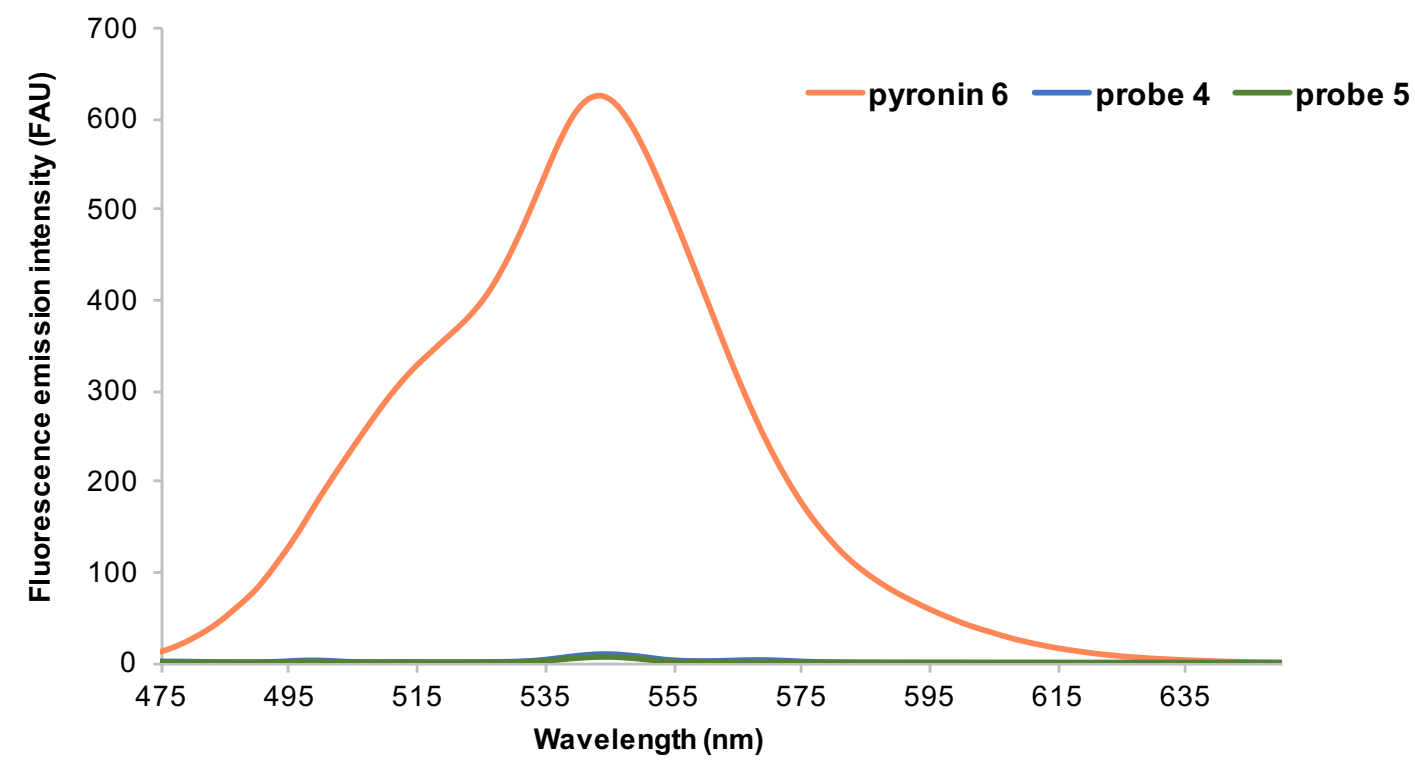

Fig. S4 Time-dependant changes in the green-yellow fluorescence intensity (Ex. $525 \mathrm{~nm} / \mathrm{Em} .545 \mathrm{~nm}$, bandwidth $5 \mathrm{~nm}$ ) of fluorogenic probe 4 (concentration: $1 \mu \mathrm{M}$ ) in the presence of PGA $(1 \mathrm{U})$ in various aqueous buffers at $37^{\circ} \mathrm{C}$

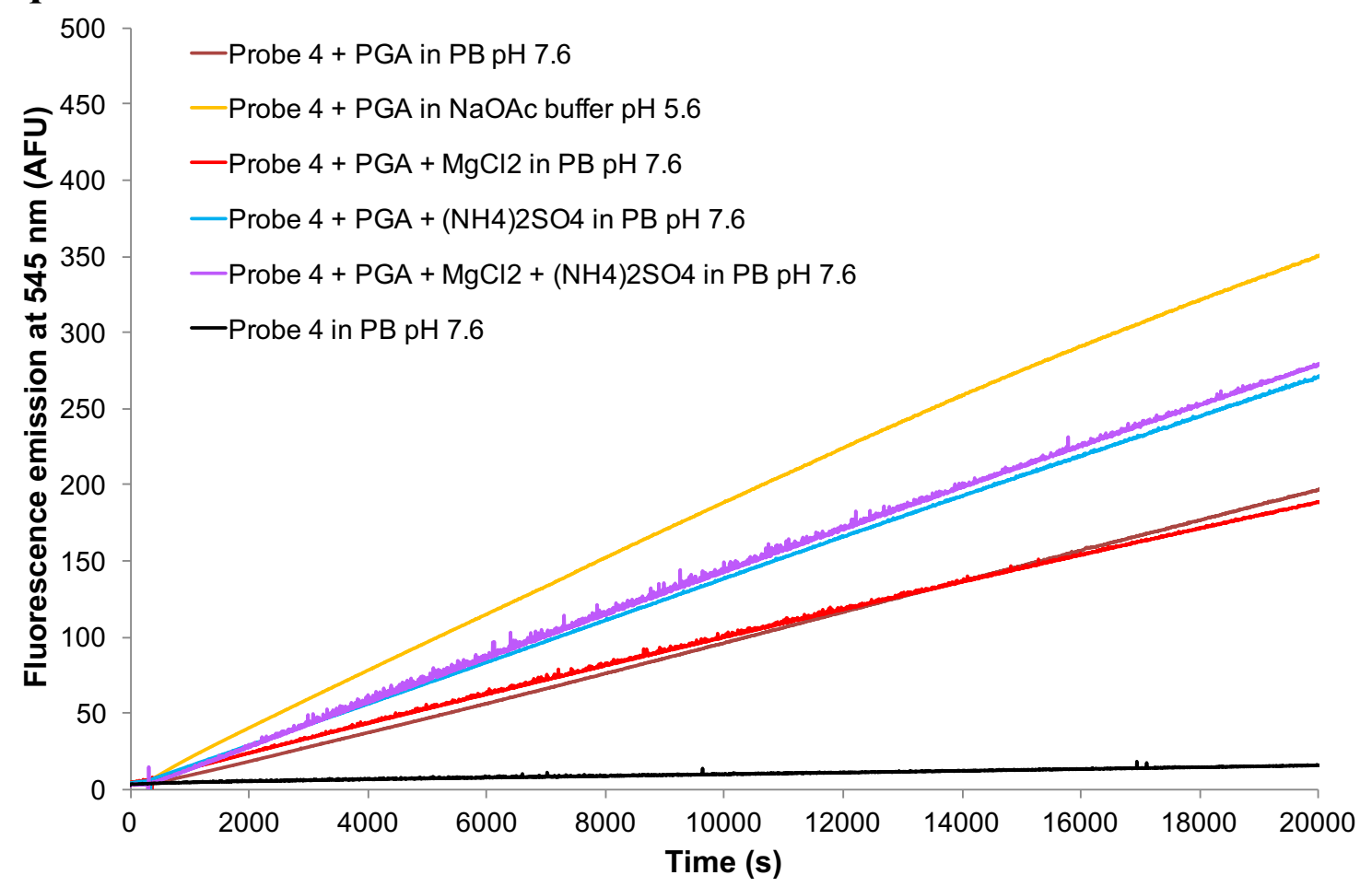


Fig. S5 Time-dependant changes in the green-yellow fluorescence intensity (Ex. $525 \mathrm{~nm} / \mathrm{Em} .545 \mathrm{~nm}$, bandwidth $5 \mathrm{~nm}$ ) of fluorogenic probe 4 in aqueous buffers at $37^{\circ} \mathrm{C}$ (blanks)

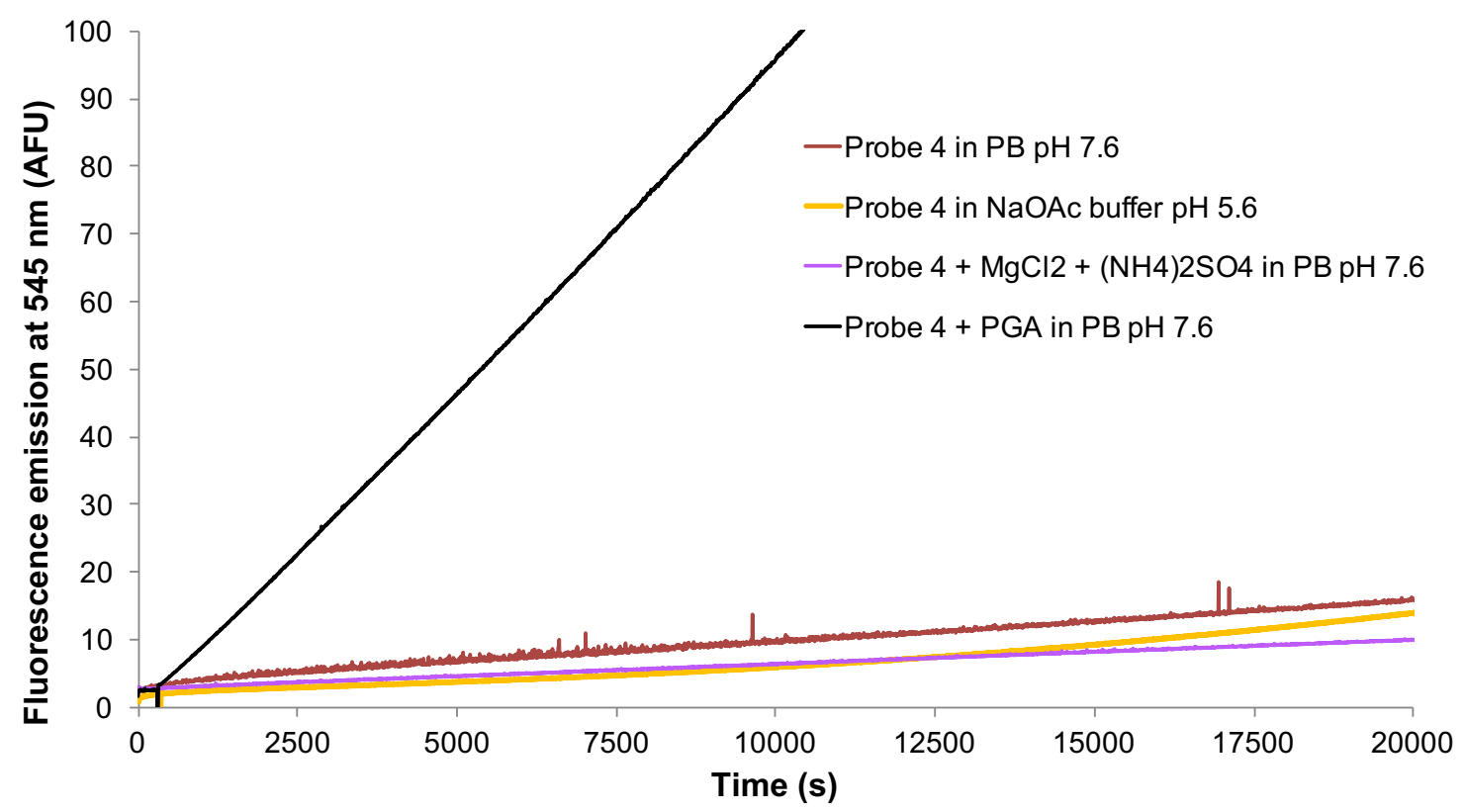

Fig. S6 Time-dependant changes in the green-yellow fluorescence intensity (Ex. $525 \mathrm{~nm} / \mathrm{Em} .545 \mathrm{~nm}$, bandwidth $5 \mathrm{~nm}$ ) of fluorogenic probe 5 in the presence of $\operatorname{LAP}\left(2 \times 10^{-3} \mathrm{U}\right)$ in various aqueous buffers at $37^{\circ} \mathrm{C}$

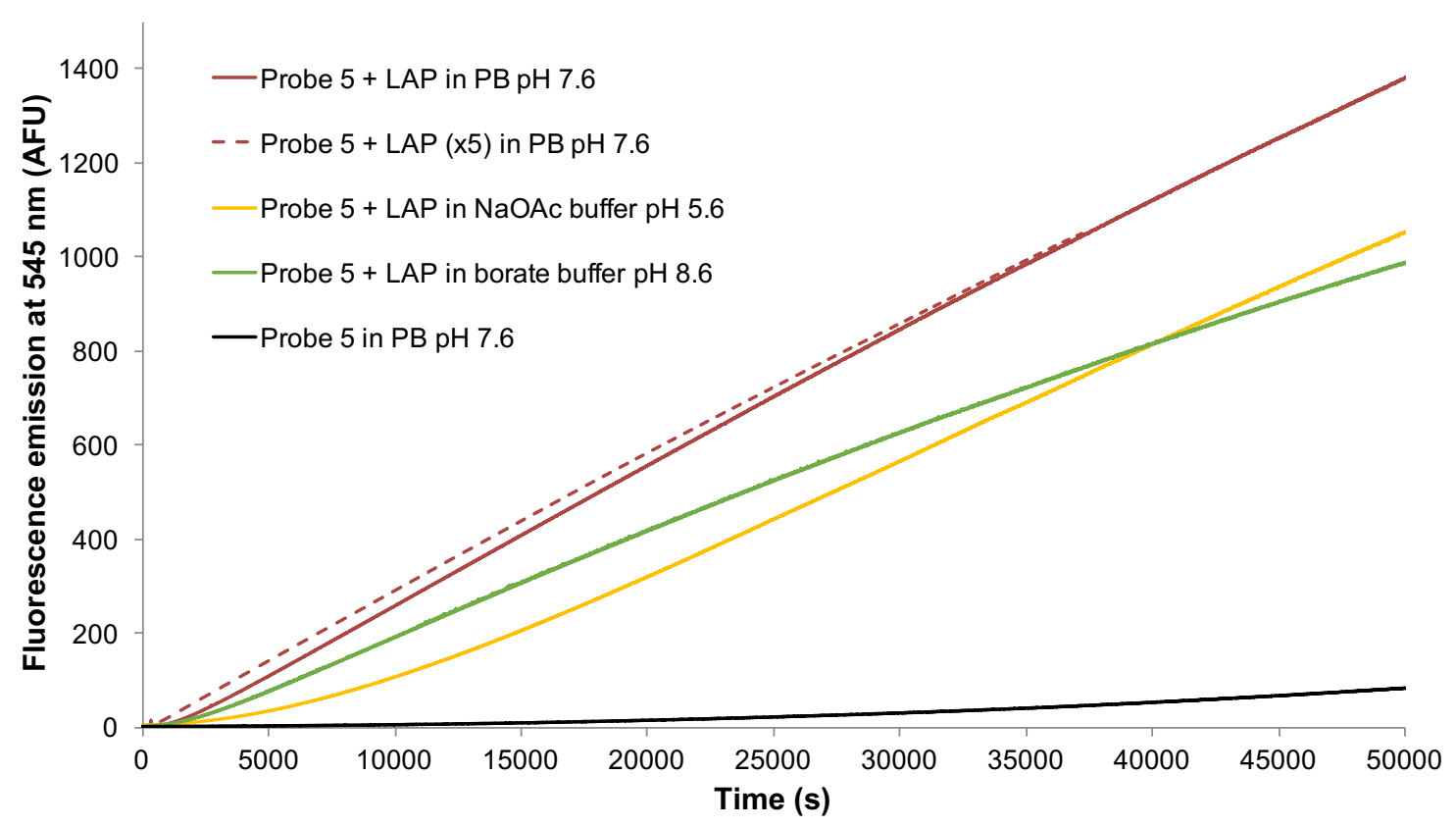


Fig. S7 Time-dependant changes in the green-yellow fluorescence intensity (Ex. $525 \mathrm{~nm} / \mathrm{Em} .545 \mathrm{~nm}$, bandwidth $5 \mathrm{~nm}$ ) of fluorogenic probe 5 in aqueous buffers at $37^{\circ} \mathrm{C}$ (blanks)

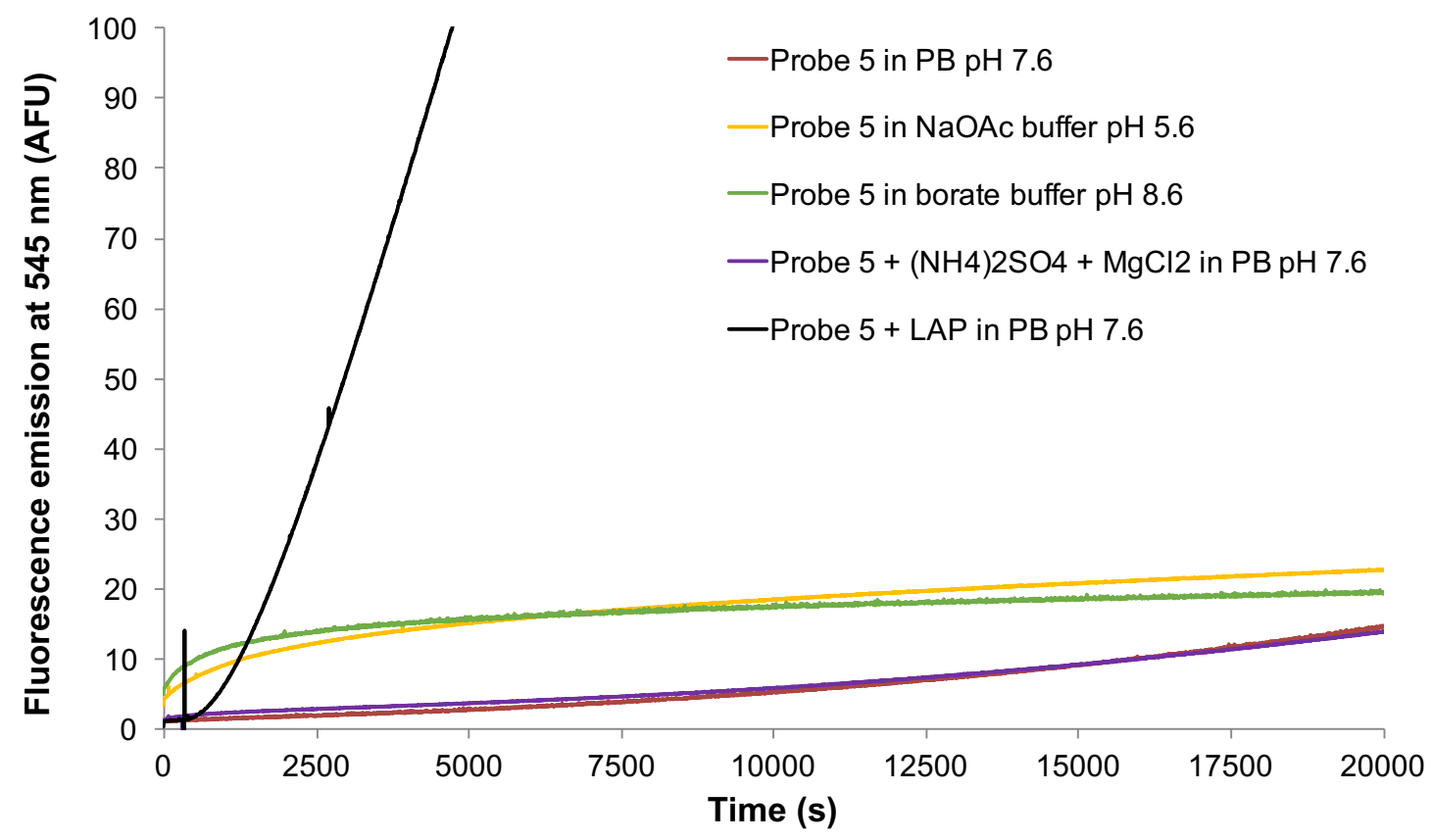

Fig. S8 Overlayed fluorescence emission spectra $(\operatorname{Ex} .460 \mathrm{~nm}$, bandwidth $5 \mathrm{~nm}$ ) of enzymatic reaction mixtures (probe 5) after $24 \mathrm{~h}$ of incubation at $37^{\circ} \mathrm{C}$ and authentic sample of pyronin 6 at the same concentration

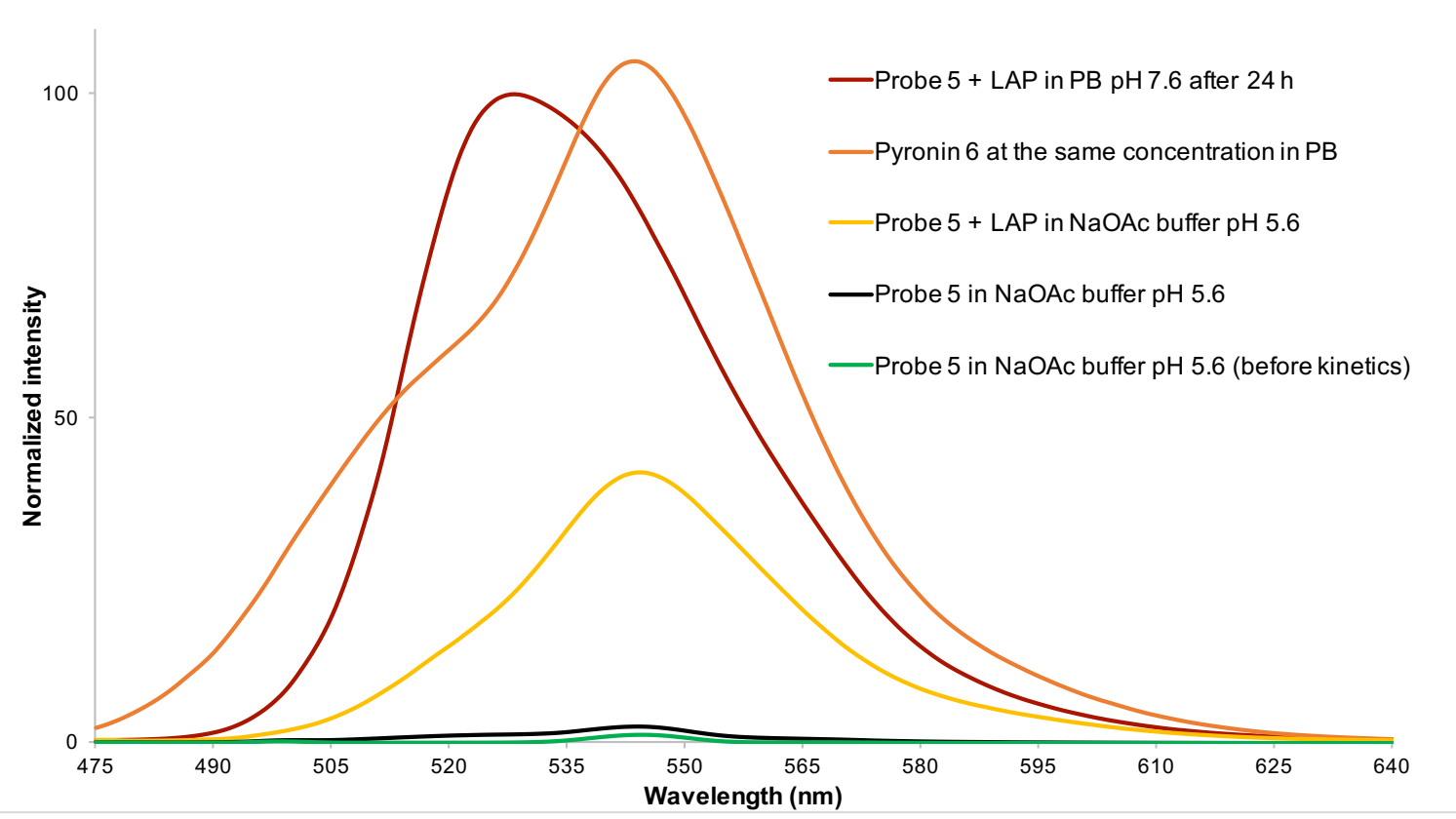


Fig. S9 Overlayed fluorescence emission spectra $(\mathrm{Ex} .460 \mathrm{~nm}$, bandwidth $5 \mathrm{~nm}$ ) of enzymatic reaction mixtures (probe 4) after $24 \mathrm{~h}$ of incubation at $37^{\circ} \mathrm{C}$

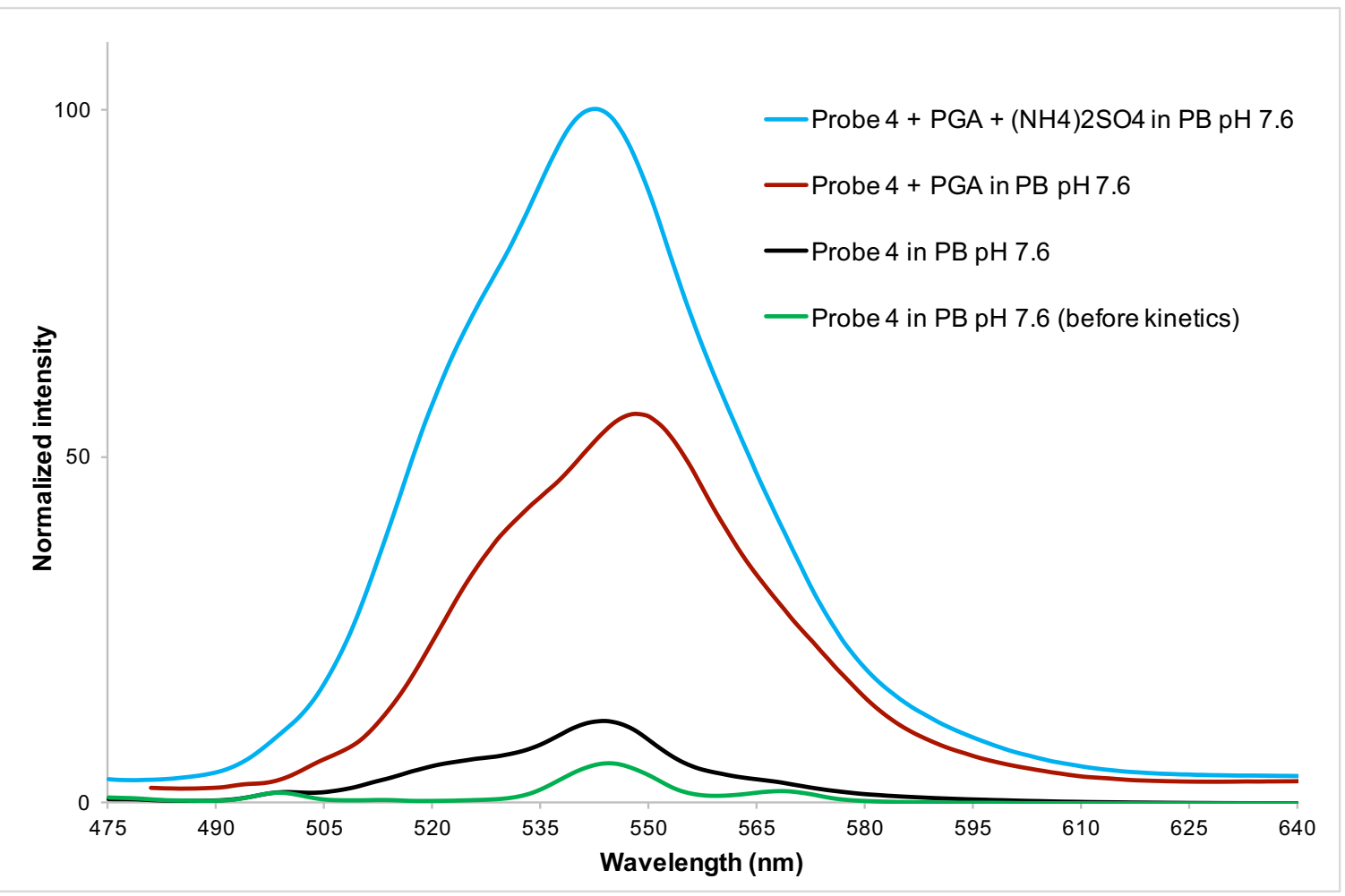

Fig. S10 RP-HPLC elution profiles (fluorescence detection, system H) of fluorogenic probes 4 and 5 before enzymatic activation

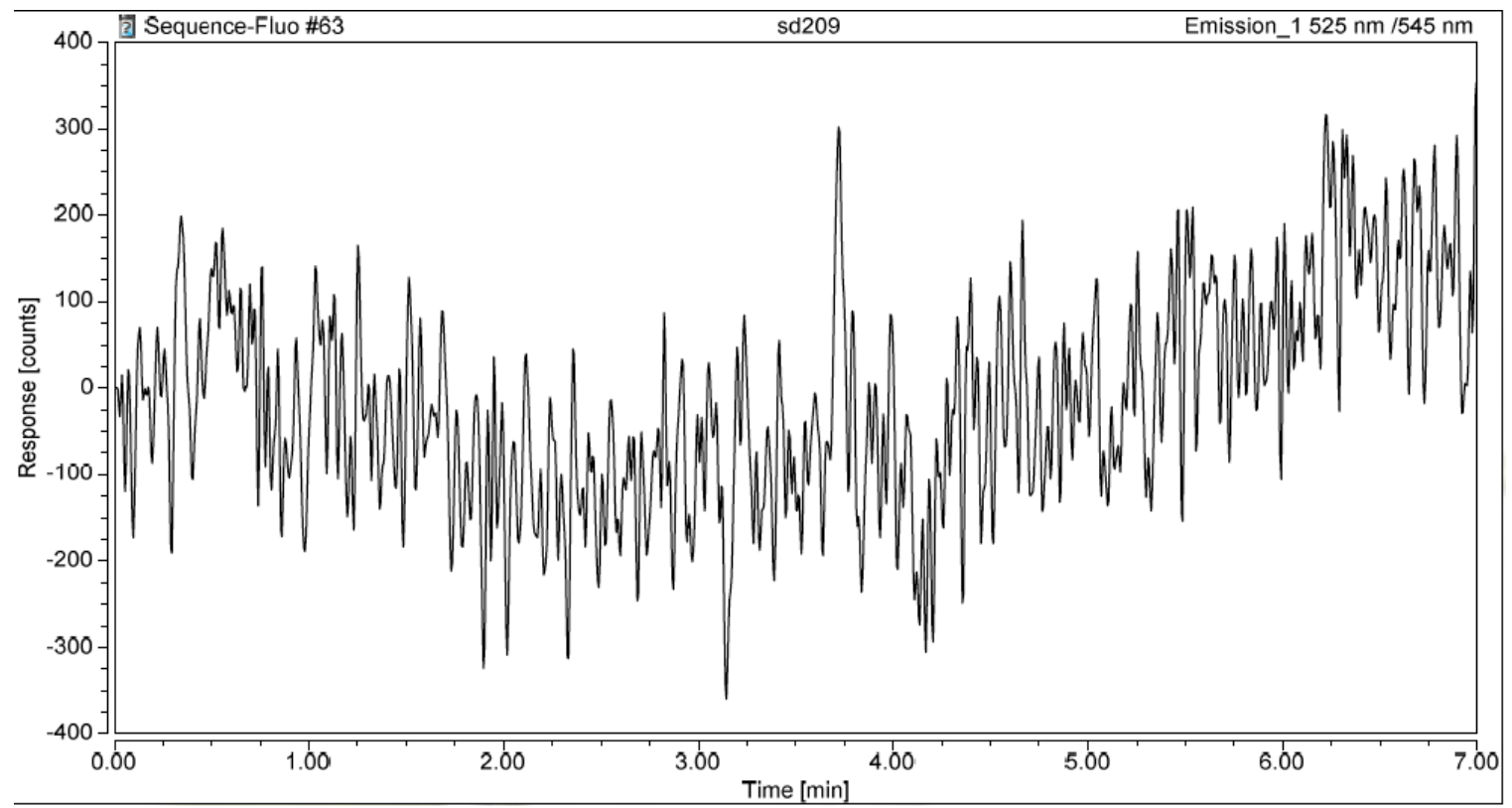




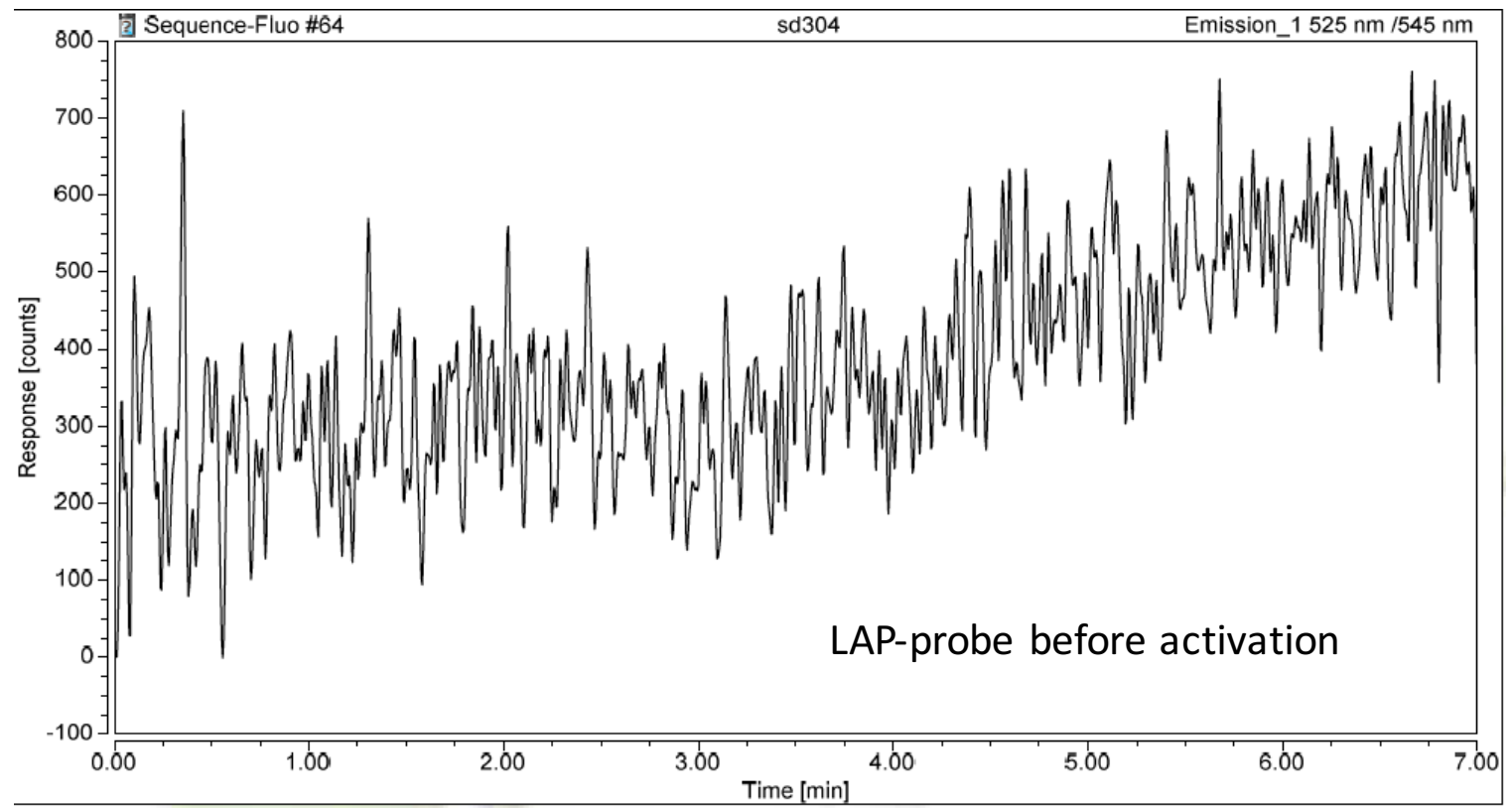

Fig. S11 RP-HPLC elution profiles (fluorescence detection, system $\mathbf{H}$ ) of fluorogenic probes 4 and 5 without enzymatic activation $(24 \mathrm{~h}$ of incubation)

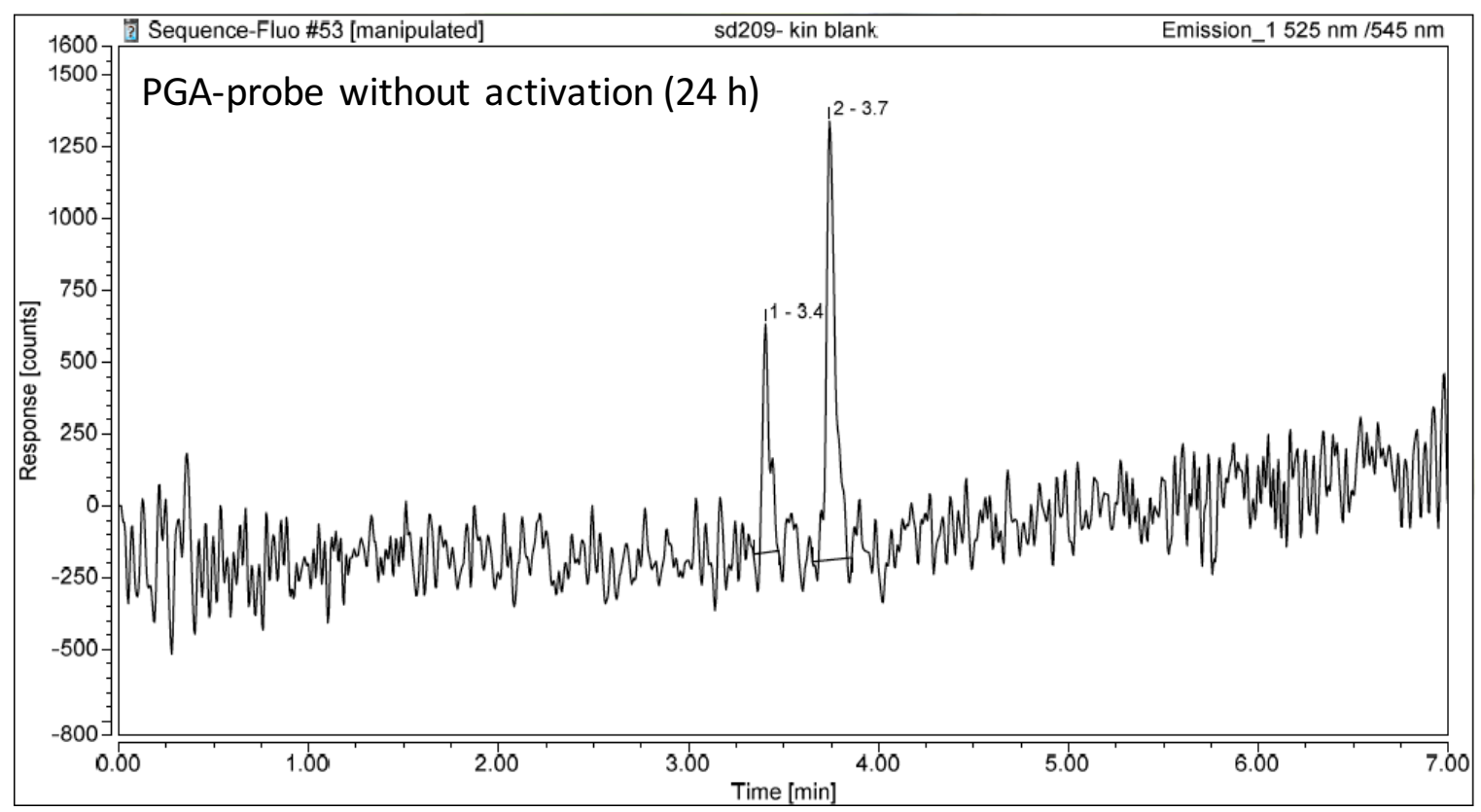




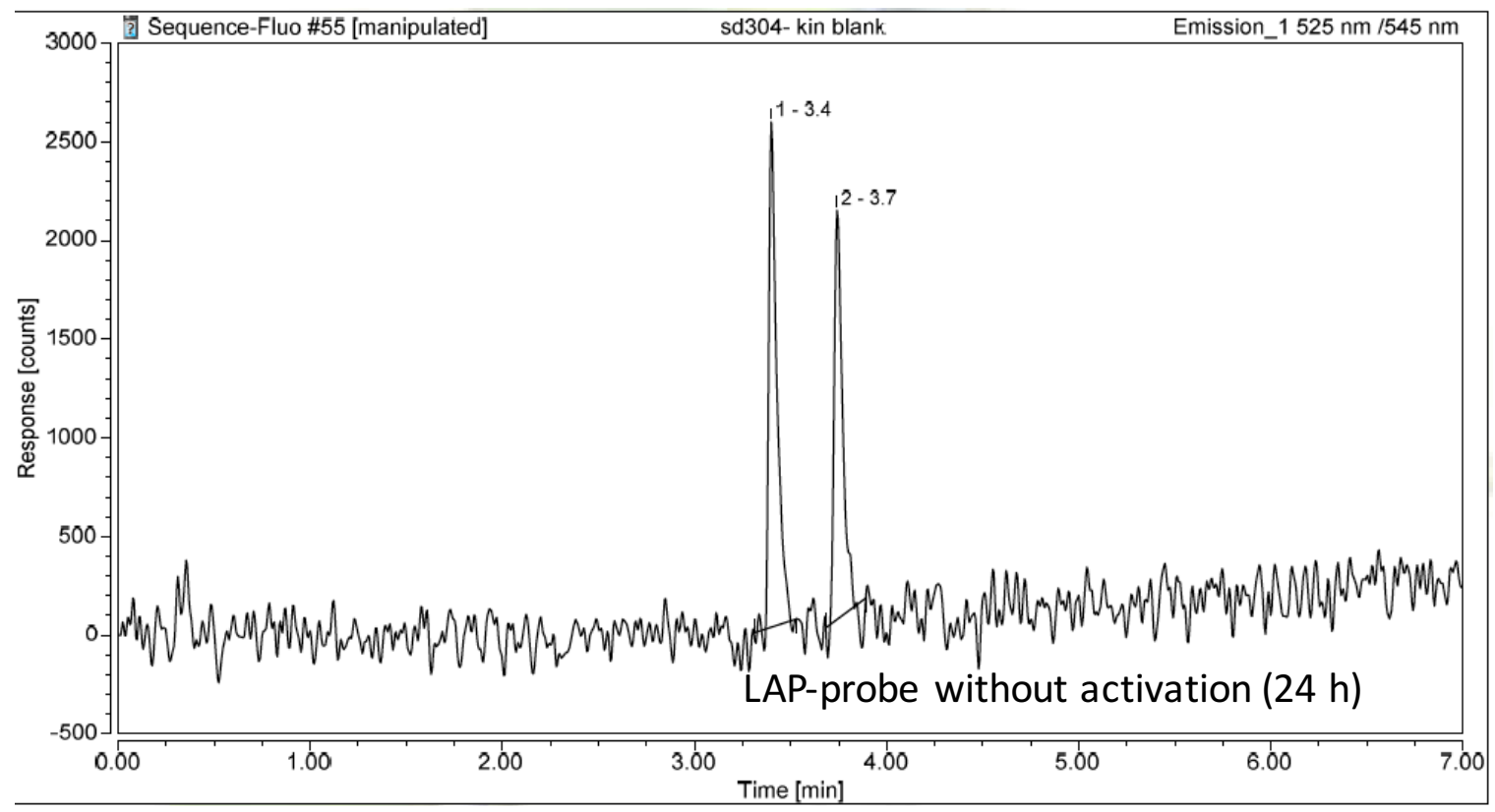

Fig. S12 RP-HPLC elution profiles (fluorescence detection, system H) of fluorogenic probes 4 and 5 after enzymatic activation $(24 \mathrm{~h})$ and reference 6

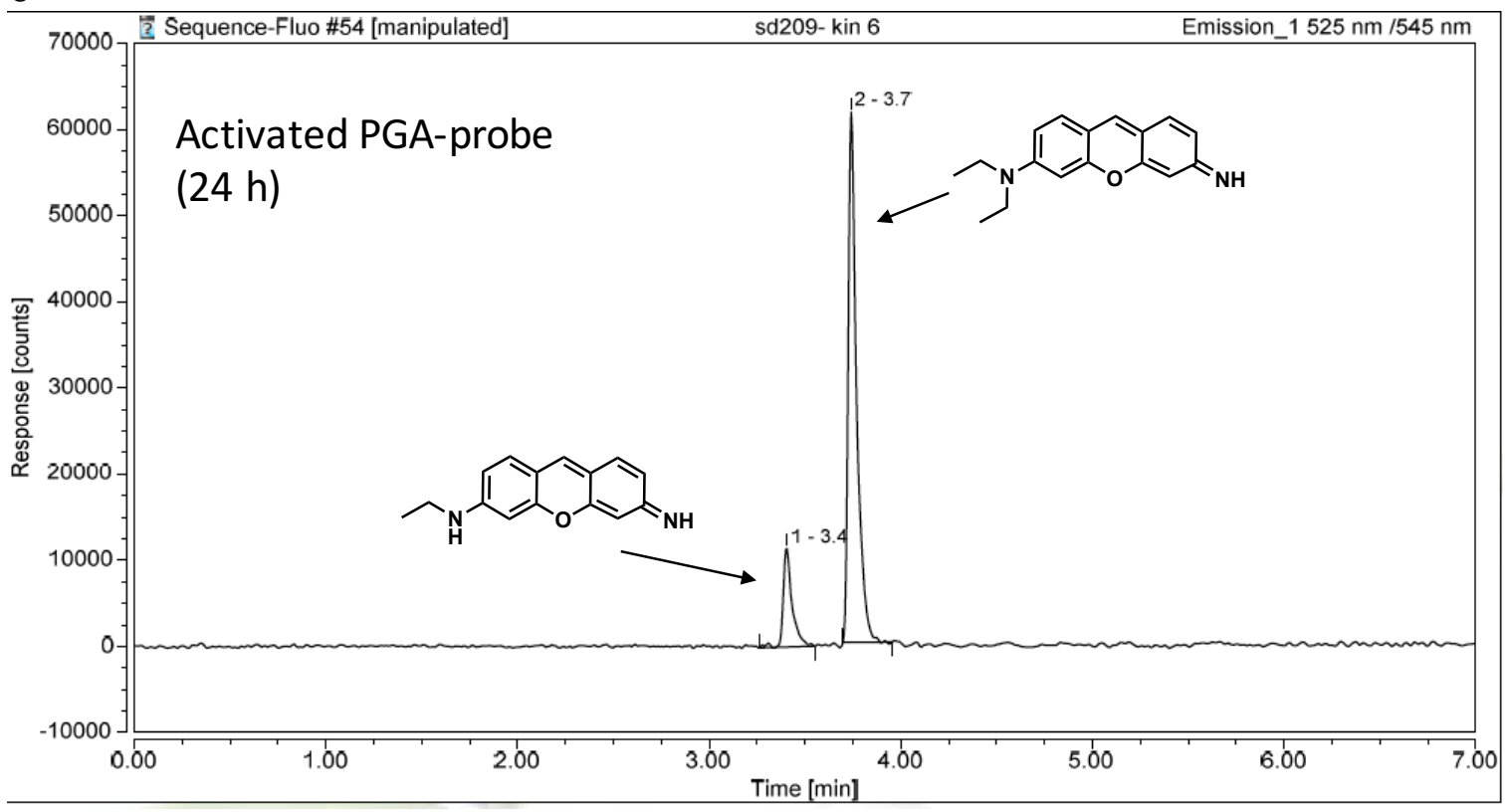




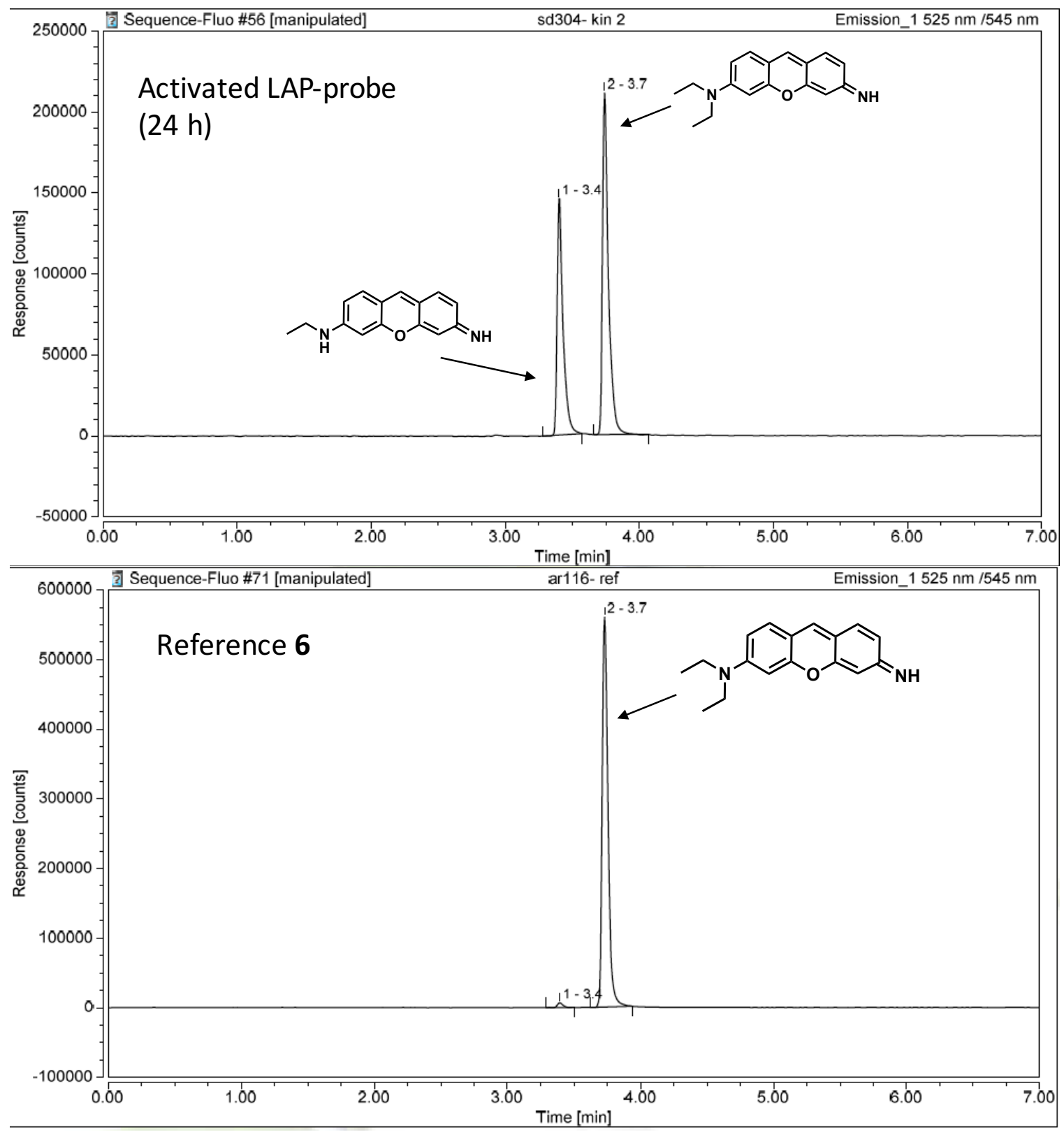


Fig. S13 Time-dependant changes in the green-yellow fluorescence intensity (Ex. $525 \mathrm{~nm} / \mathrm{Em} .545 \mathrm{~nm}$, bandwidth $5 \mathrm{~nm}$ ) of fluorogenic probe 4 (concentration: $1 \mu \mathrm{M})$ in the presence of LAP $\left(2 \times 10^{-3} \mathrm{U}\right)$ in PB at $37^{\circ} \mathrm{C}$ (negative control)

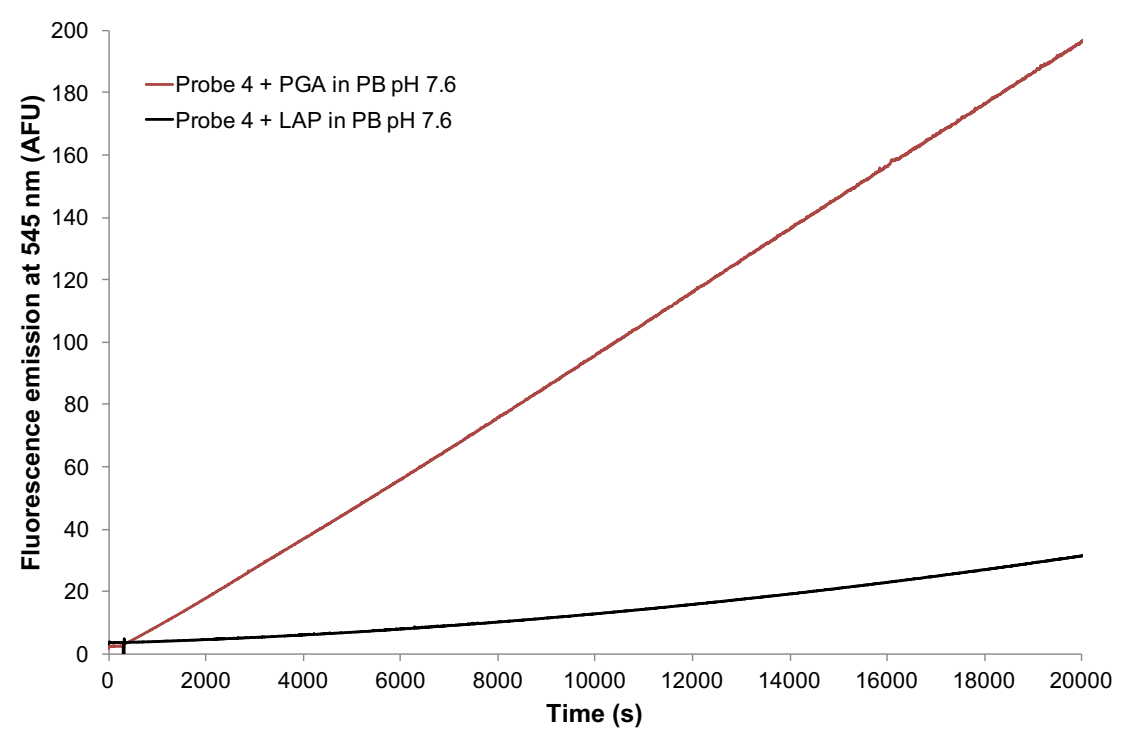

Fig. S14 Time-dependant changes in the green-yellow fluorescence intensity (Ex. $525 \mathrm{~nm} / \mathrm{Em} .545 \mathrm{~nm}$, bandwidth $5 \mathrm{~nm}$ ) of fluorogenic probe 5 (concentration: $1 \mu \mathrm{M}$ ) in the presence of PGA (1 U) in PB at 37 ${ }^{\circ} \mathrm{C}$ (negative control)

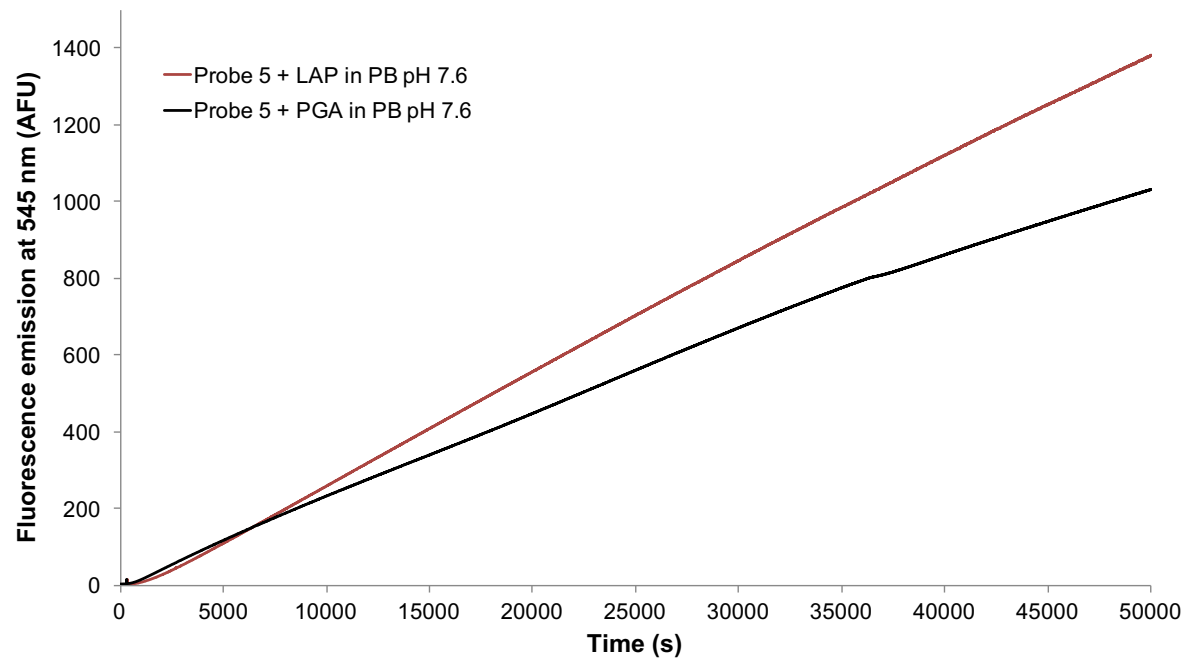


Fig. S15 RP-HPLC-MS analyses - Identification of "relevant" molecules/ intermediates formed during the enzymatic activation of probes 4 and 5 (system G)
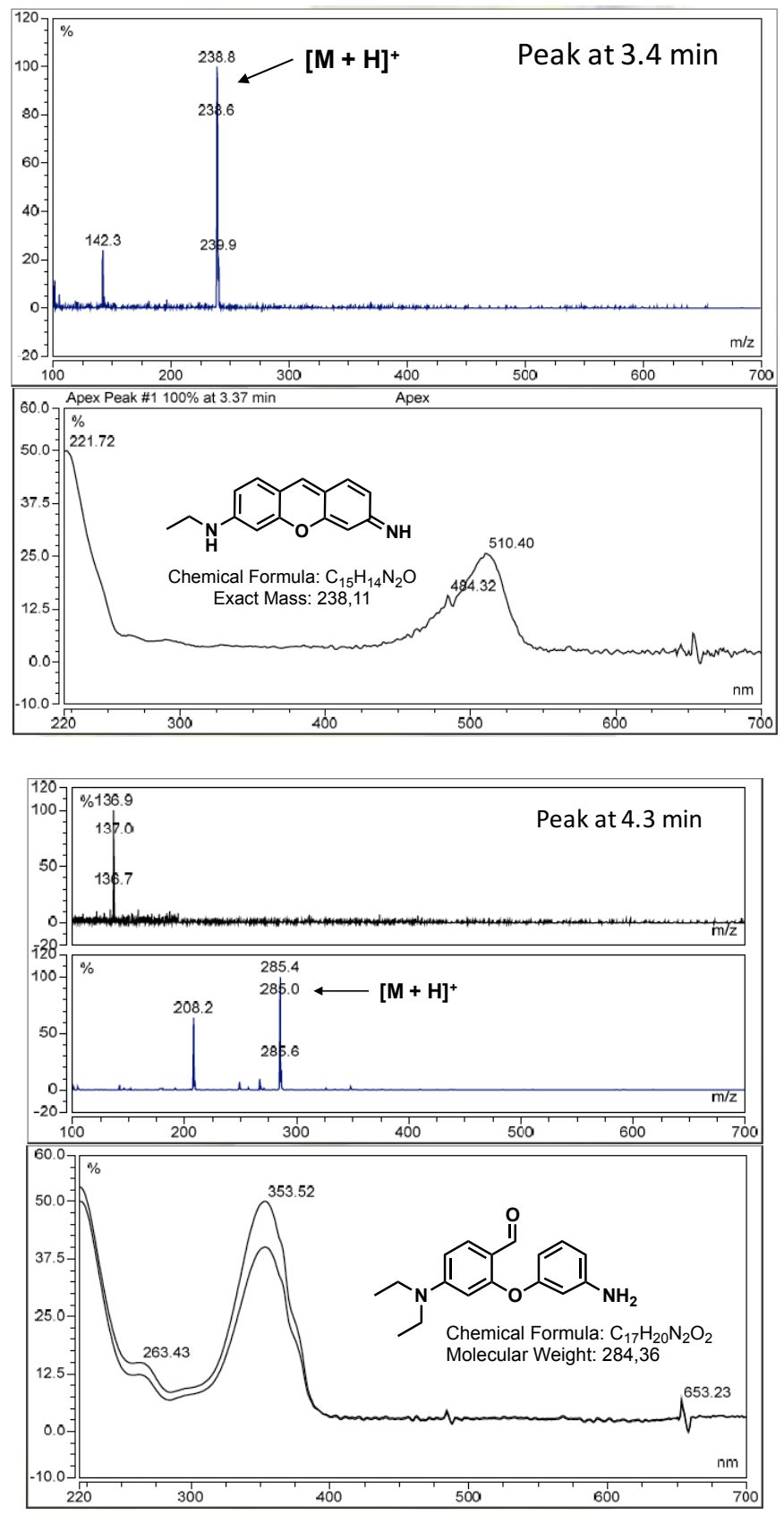
Fig. S16 RP-HPLC elution profiles (system G) of fluorogenic probe 4 after incubation in PB alone (0 min and after $24 \mathrm{~h}$ ) or with enzyme (PGA: $2 \mathrm{~h}, 5 \mathrm{~h}, 8 \mathrm{~h}$ and $24 \mathrm{~h}$ )
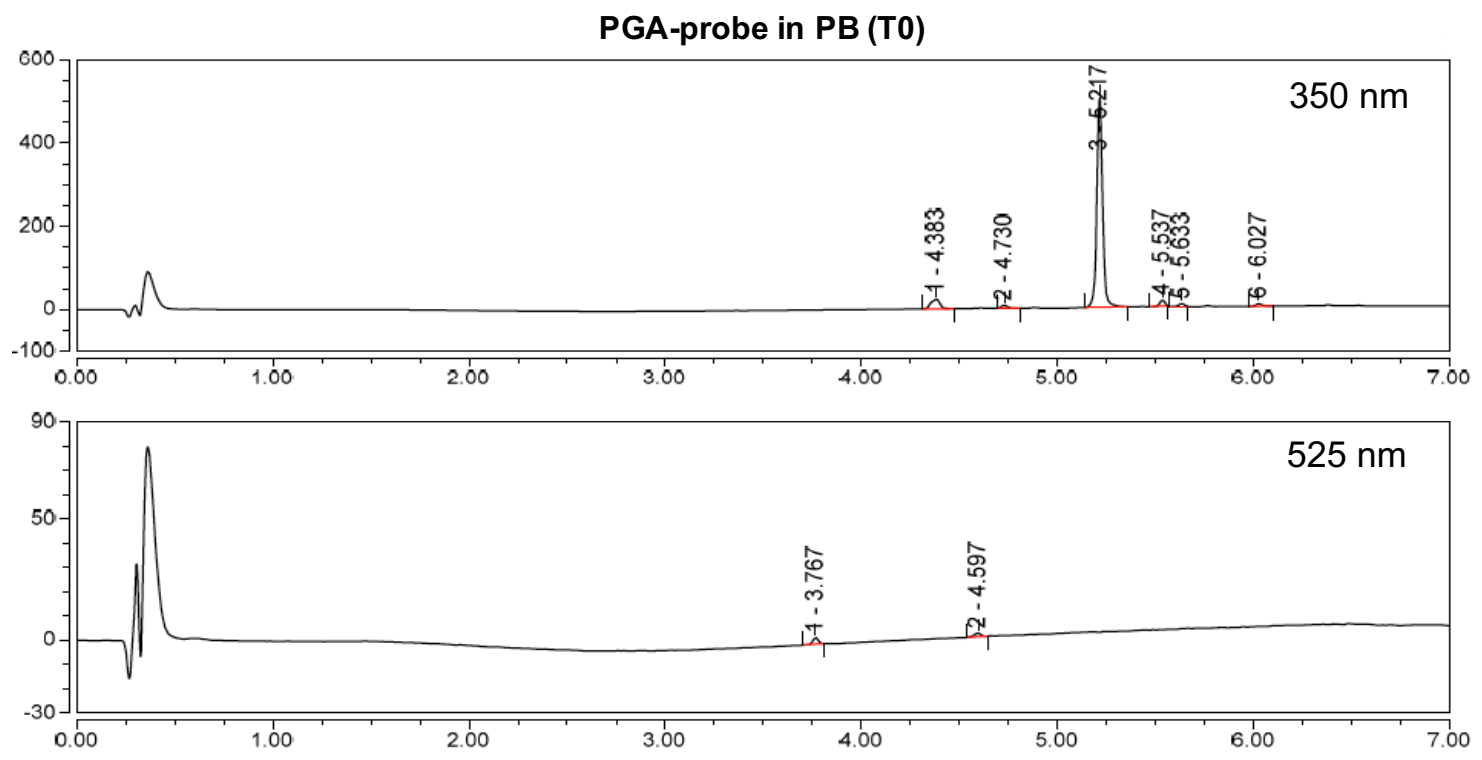

PGA-probe in PB after $24 \mathrm{~h}$

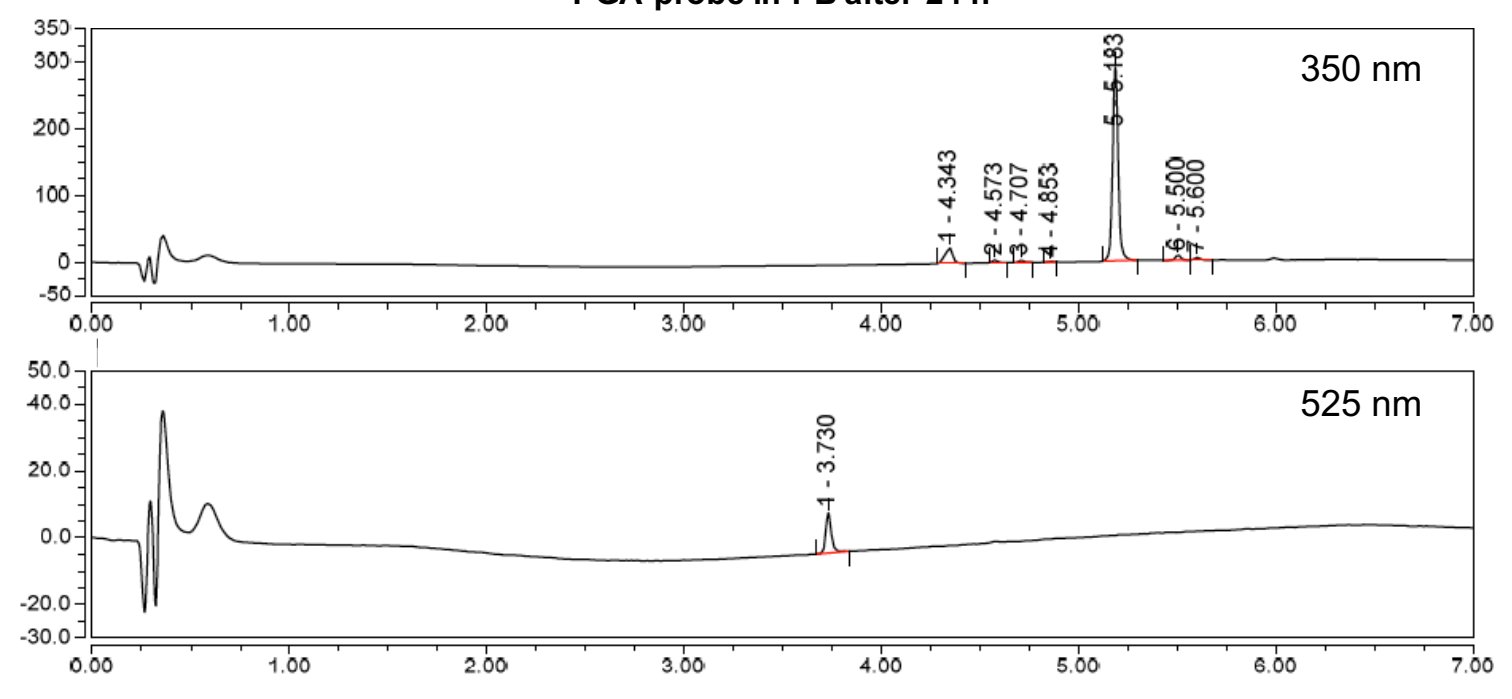


PGA-probe with PGA (1 U) after 2 h
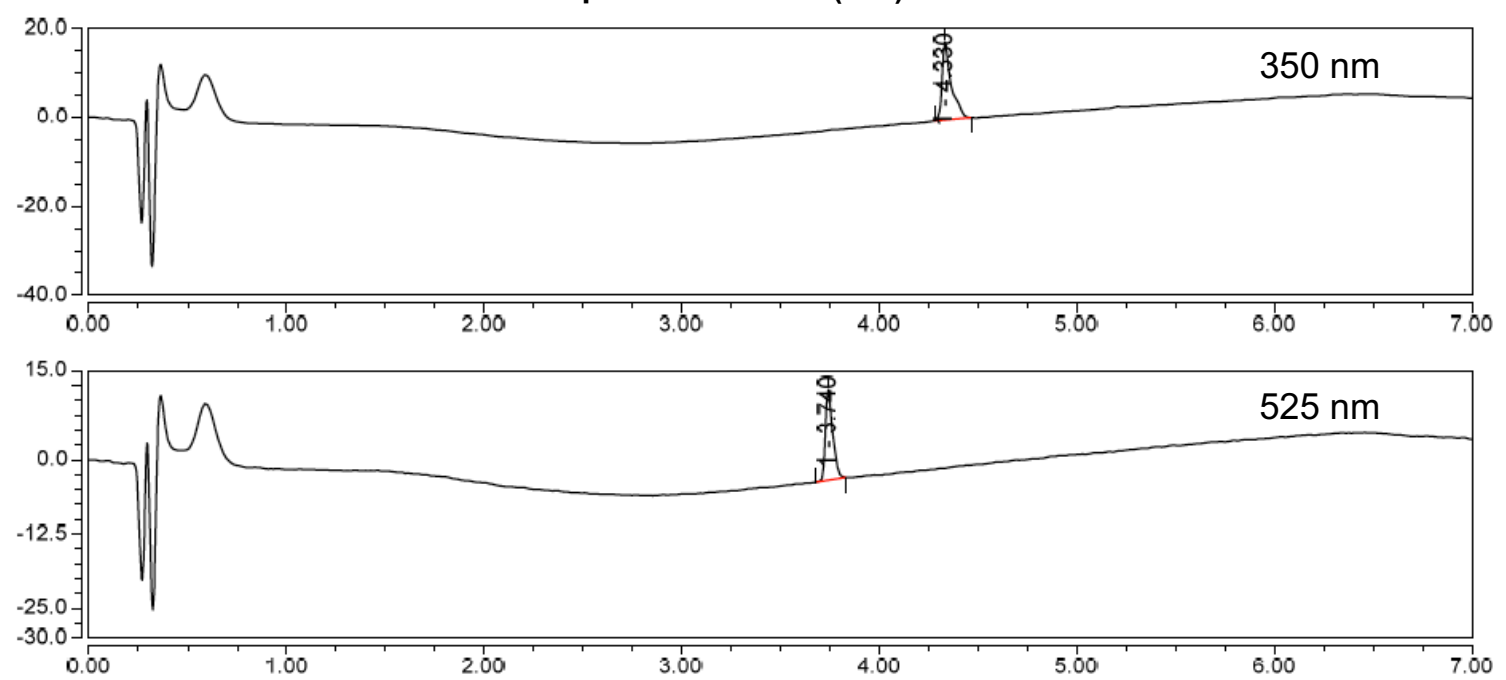

PGA-probe with PGA (1 U) after 5 h
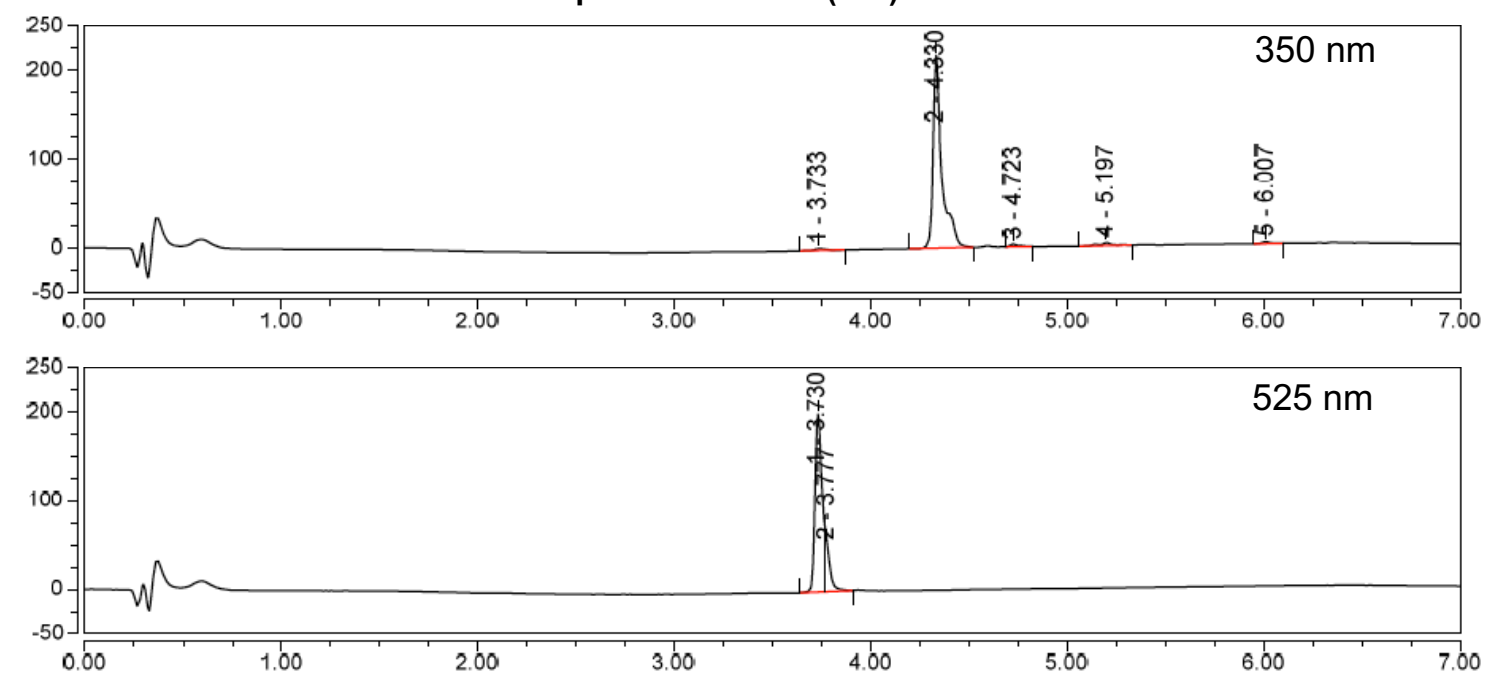

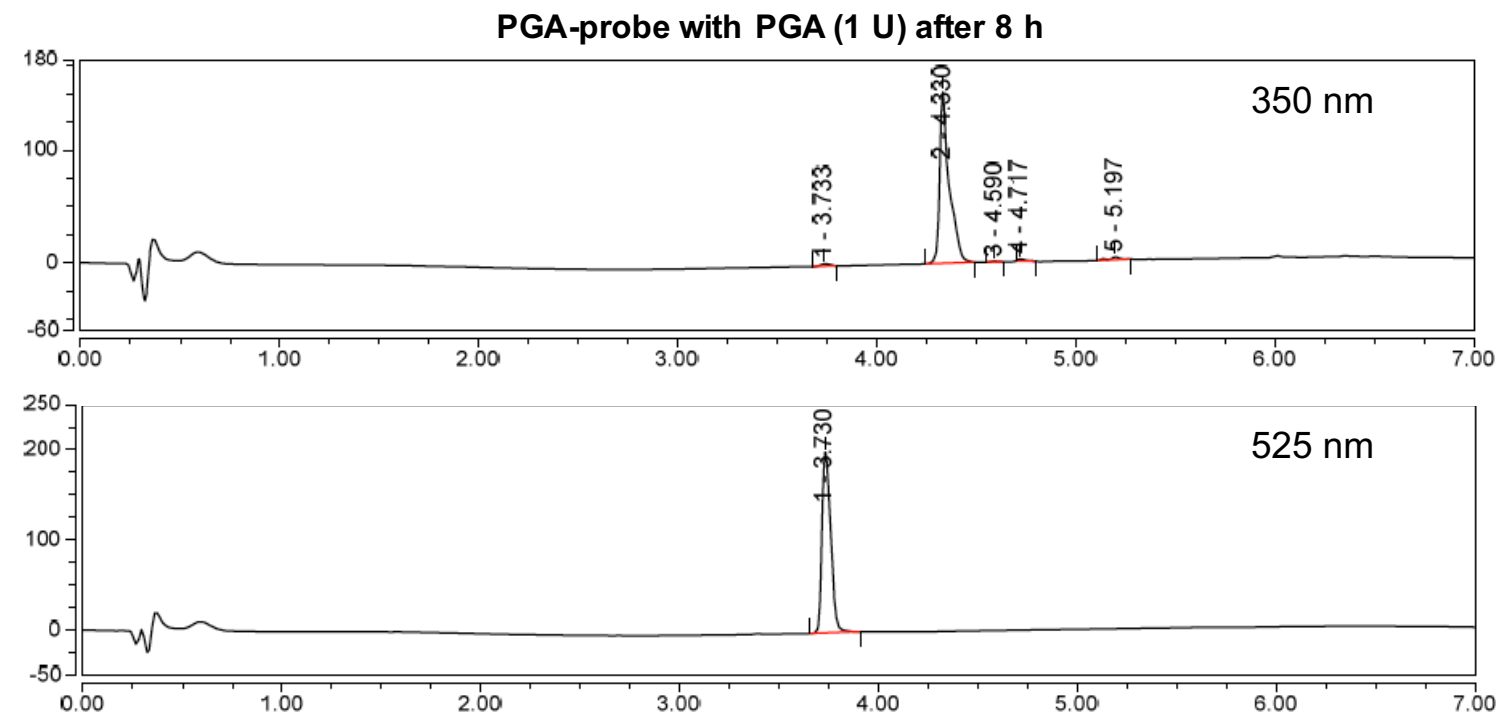

PGA-probe with PGA (1 U) after $24 \mathrm{~h}$
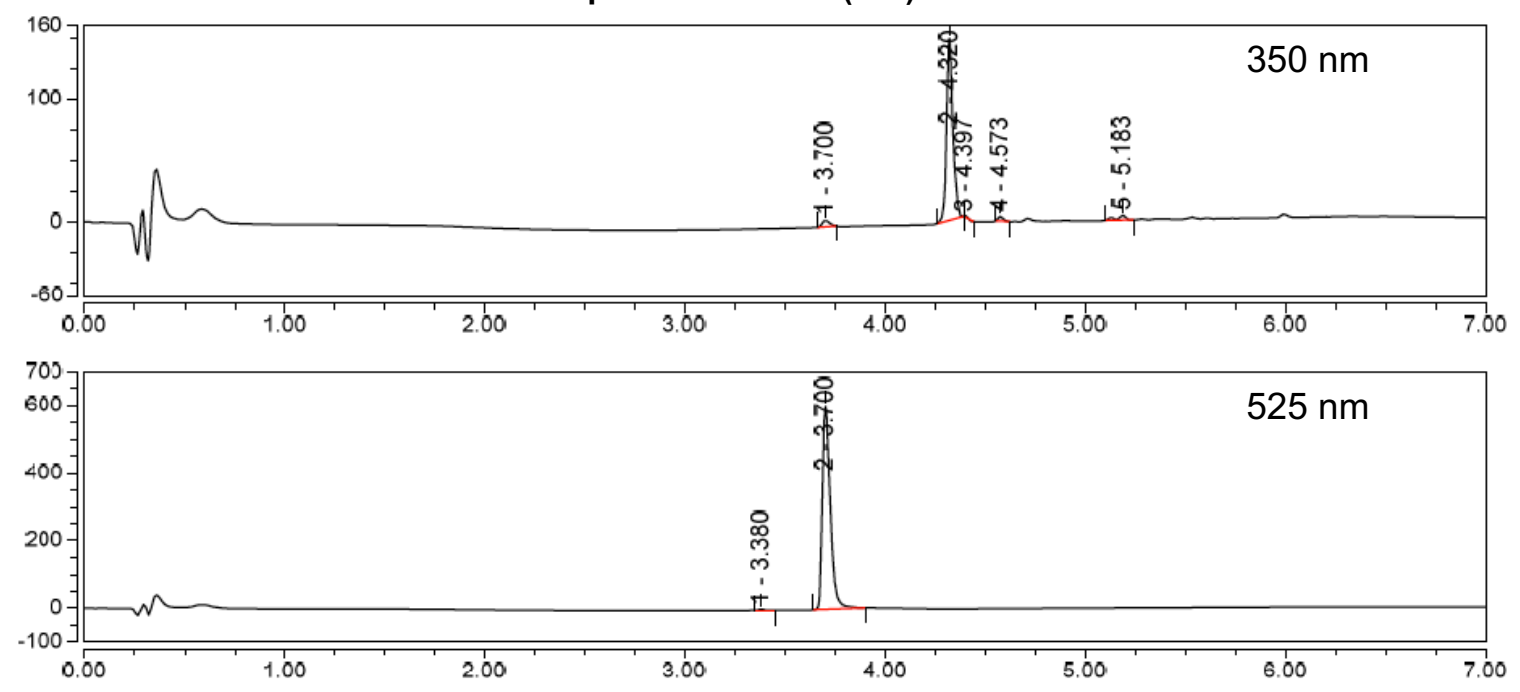
Fig. S17 RP-HPLC elution profiles (system G) of fluorogenic probe 5 after incubation in PB alone (0 min and after $24 \mathrm{~h}$ ) or with enzyme (LAP: $2 \mathrm{~h}, 5 \mathrm{~h}, 8 \mathrm{~h}$ and $24 \mathrm{~h}$ )
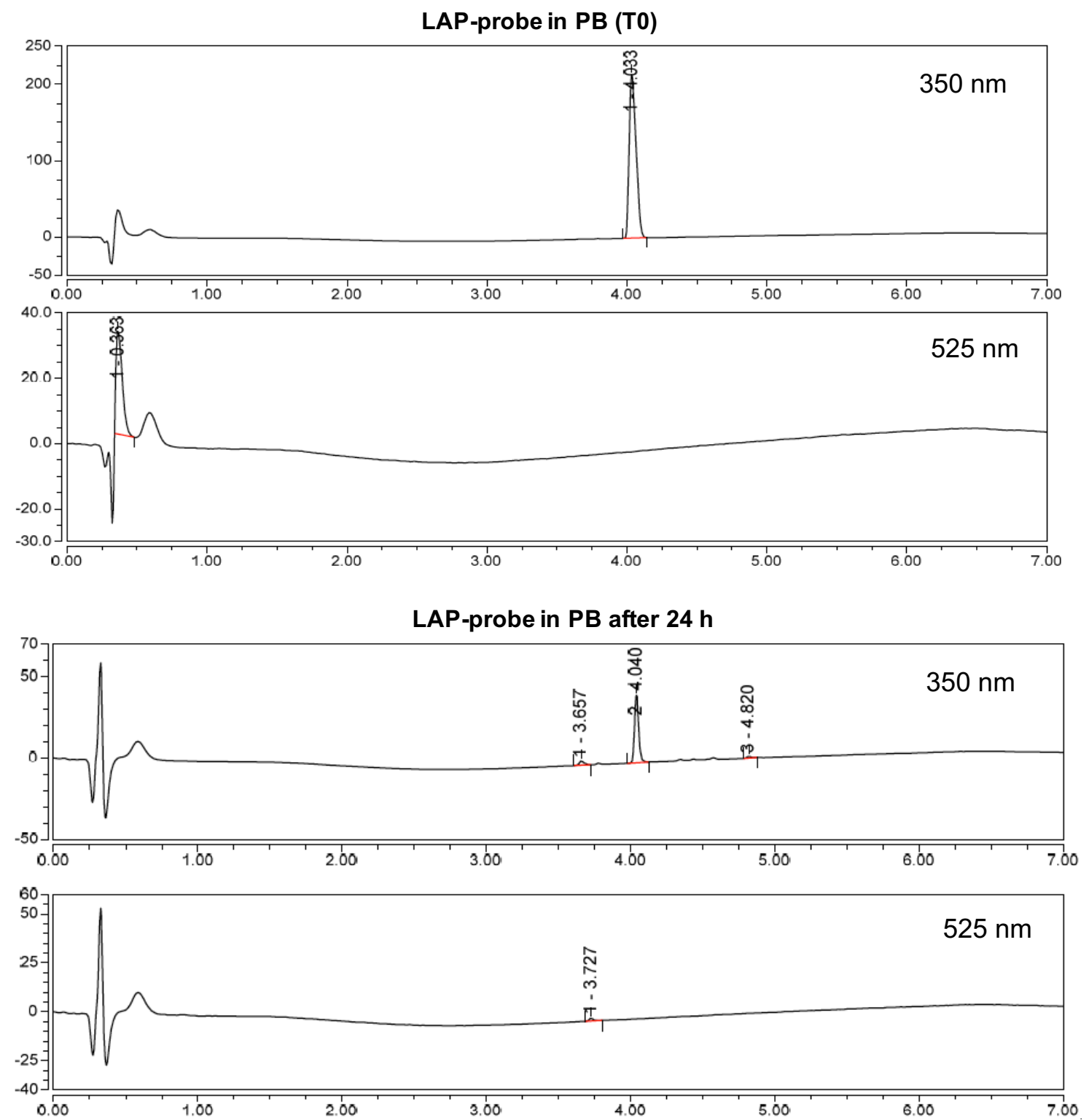

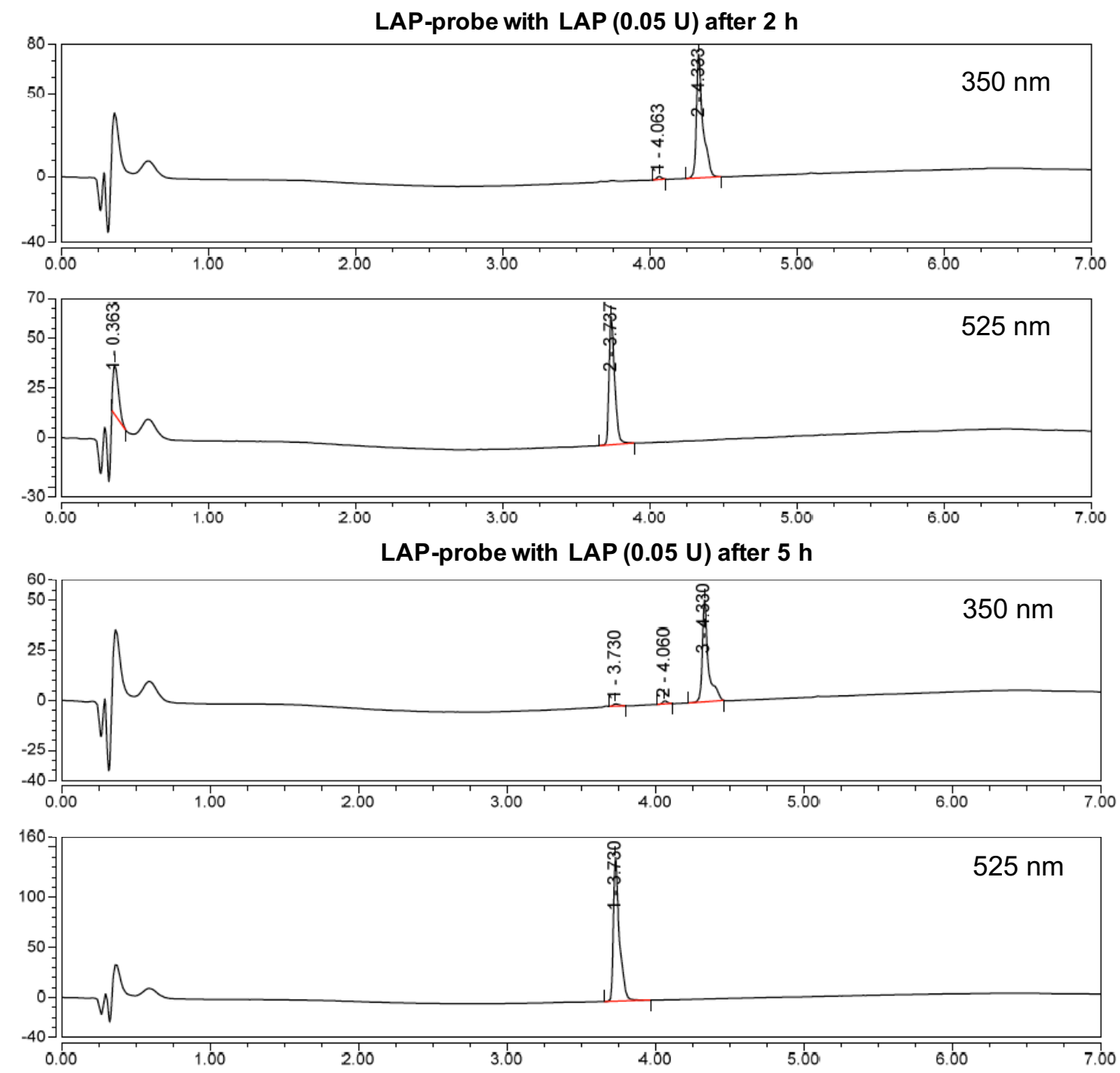

LAP-probe with LAP (0.05 U) after $8 \mathrm{~h}$
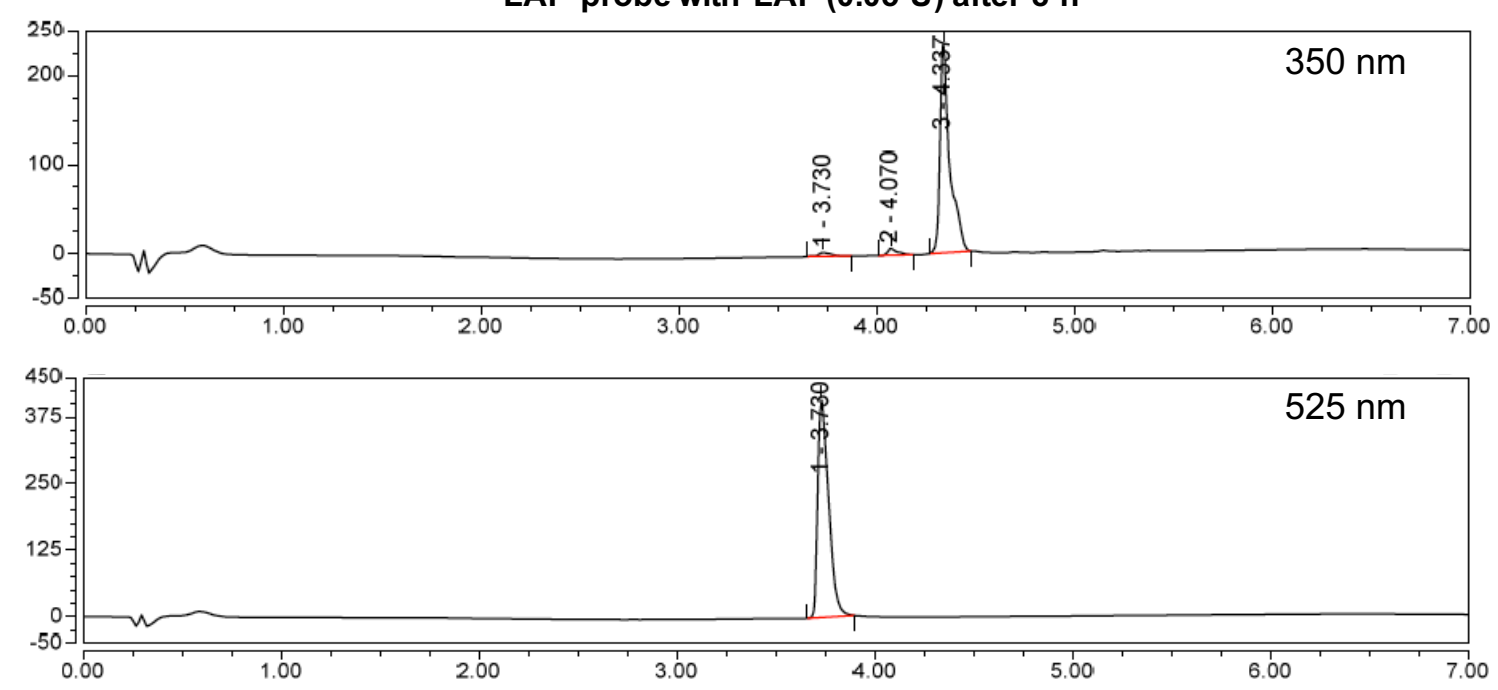
LAP-probe with LAP (0.05 U) after $24 \mathrm{~h}$
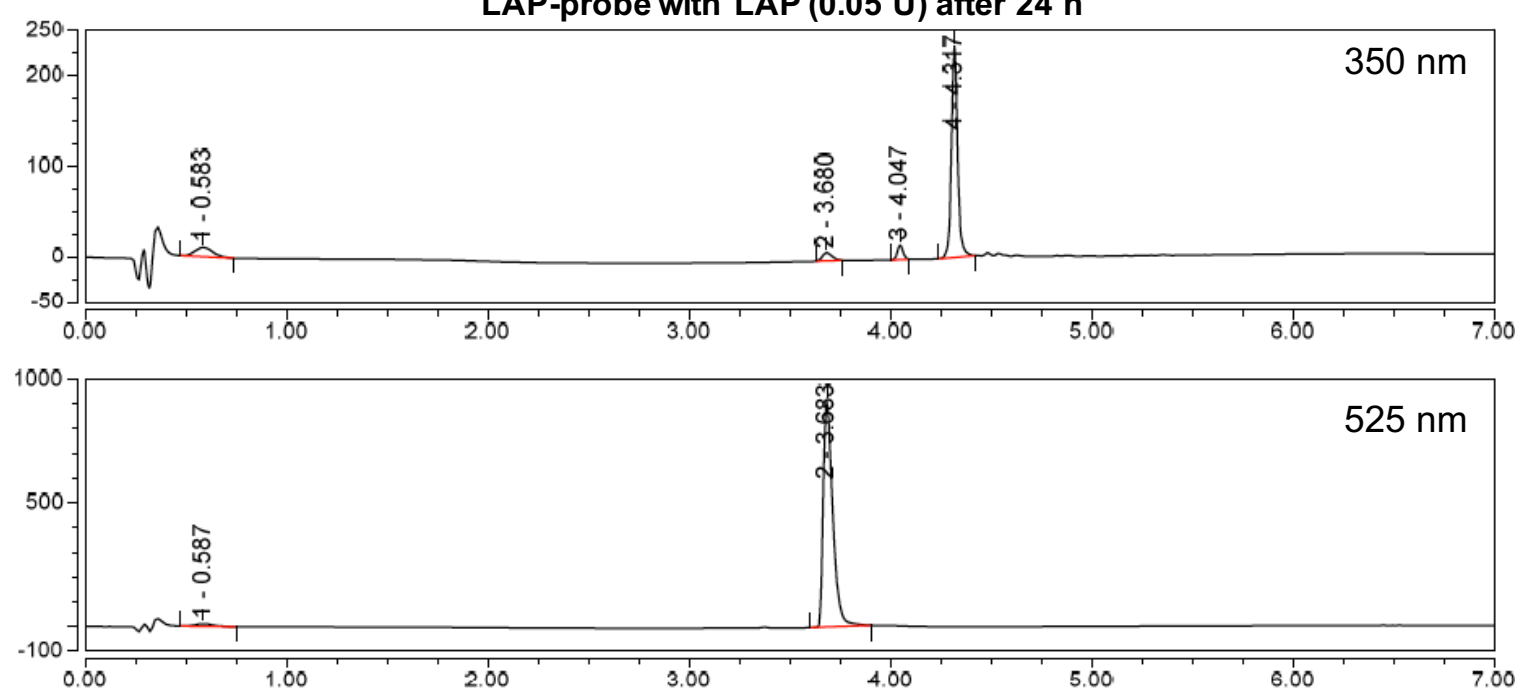